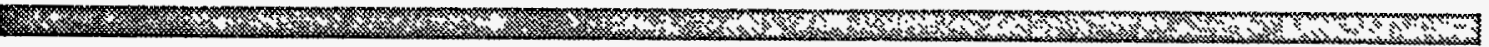

Electric Power High-Voltage Transmission Lines: Design Options, Cost, and Electric and Magnetic Field Levels

by J.B. Stoffel, * E.D. Pentecost, R.D. Roman, and P.A. Traczyk

Environmental Assessment Division,

Argonne National Laboratory, 9700 South Cass Avenue, Argonne, Illinois 60439

November 1994

Work sponsored by United States Department of Energy,

Assistant Secretary for Fossil Energy, Office of Fuels Program

"Stoffel is affiliated with Argonne's Electronics and Computing Technologies Division.

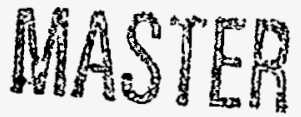


This report is printed on recycled paper. 


\section{DISCLAIMER}

This report was prepared as an account of work sponsored by an agency of the United States Government. Neither the United States Government nor any agency thereof, nor any of their employees, make any warranty, express or implied, or assumes any legal liability or responsibility for the accuracy, completeness, or usefulness of any information, apparatus, product, or process disclosed, or represents that its use would not infringe privately owned rights. Reference herein to any specific commercial product, process, or service by trade name, trademark, manufacturer, or otherwise does not necessarily constitute or imply its endorsement, recommendation, or favoring by the United States Government or any agency thereof. The views and opinions of authors expressed herein do not necessarily state or reflect those of the United States Government or any agency thereof. 


\section{DISCLAIMER}

Portions of this document may be illegible in electronic image products. Images are produced from the best available original document. 


\section{CONTENTS}

ACKNOWLEDGMENTS $\ldots \ldots \ldots \ldots \ldots \ldots \ldots \ldots \ldots \ldots \ldots$ viii

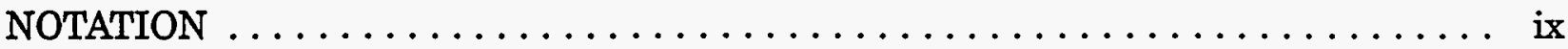

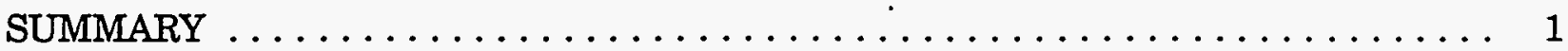

1 INTRODUCTION $\ldots \ldots \ldots \ldots \ldots \ldots \ldots \ldots \ldots \ldots \ldots \ldots \ldots \ldots \ldots \ldots \ldots \ldots \ldots$

1.1 Purpose and Scope $\ldots \ldots \ldots \ldots \ldots \ldots \ldots \ldots \ldots \ldots \ldots \ldots \ldots \ldots \ldots \ldots$

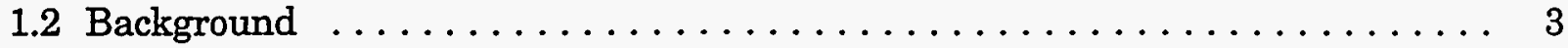

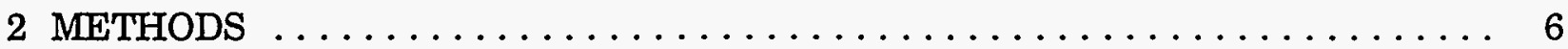

2.1 Search of the Literature $\ldots \ldots \ldots \ldots \ldots \ldots \ldots \ldots \ldots \ldots \ldots \ldots \ldots \ldots \ldots$

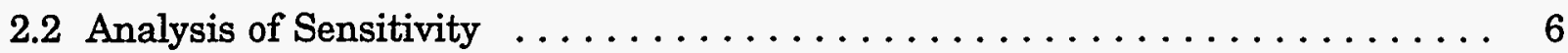

2.3 Analysis of Cost versus Fields . . . . . . . . . . . . . . . . 7

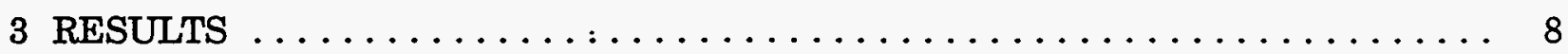

3.1 Considerations for Planning and Design $\ldots \ldots \ldots \ldots \ldots \ldots \ldots \ldots$

3.1.1 Number of Lines $\ldots \ldots \ldots \ldots \ldots \ldots \ldots \ldots \ldots \ldots, 8$

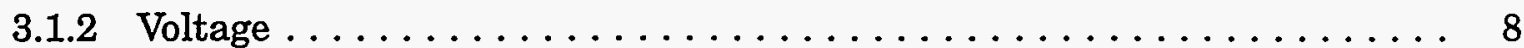

3.1.3 Height of Conductors $\ldots \ldots \ldots \ldots \ldots \ldots \ldots \ldots \ldots \ldots \ldots, 8$

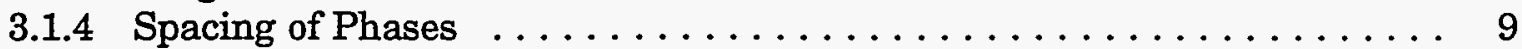

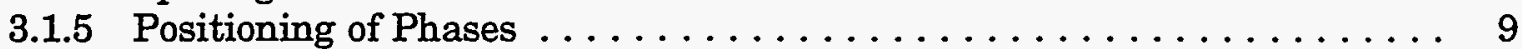

3.1.6 Balance of Phases $\ldots \ldots \ldots \ldots \ldots \ldots \ldots \ldots \ldots \ldots \ldots, 9$

3.1.7 Spacing and Location of Conductors $\ldots \ldots \ldots \ldots \ldots \ldots \ldots \ldots \ldots$

3.1.8 Size and Bundling of Conductors $\ldots \ldots \ldots \ldots \ldots \ldots \ldots \ldots \ldots \ldots$

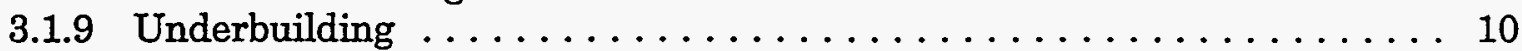

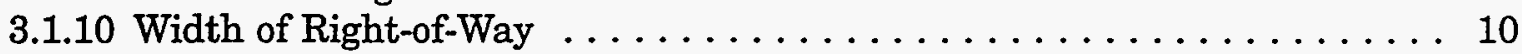

3.1.11 Design Practices of Utilities . . . . . . . . . . . . . . . 11

3.2 General Methods for Electric and Magnetic Field Reduction . . . . . . . . . . 11

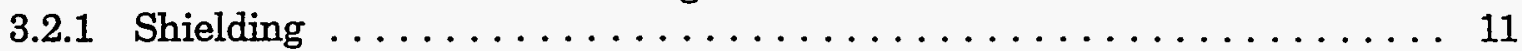

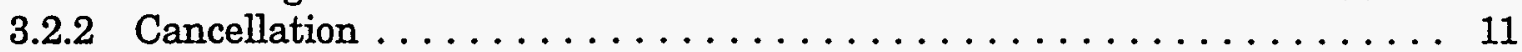

3.3 Specific Options for Electric and Magnetic Field Reduction ............ 12

3.3.1 High-Voltage ac Transmission Lines . . . . . . . . . . . . . 12

3.3.1.1 Configuration for 765-kV ac Transmission Lines . . . . . . . 12

3.3.1.2 Configurations for $500-\mathrm{kV}$ ac Transmission Lines ......... 14

3.3.1.3 Configurations for $345-\mathrm{kV}$ ac Transmission Lines ......... 19

3.3.2 Direct-Current Transmission Lines $\ldots \ldots \ldots \ldots \ldots \ldots \ldots \ldots \ldots . \ldots \ldots$

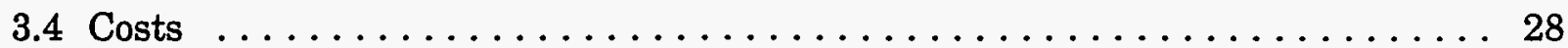

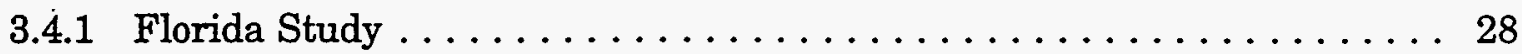

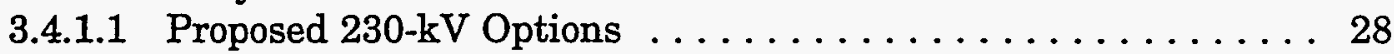

3.4.1.2 Proposed 500-kV Options $\ldots \ldots \ldots \ldots \ldots \ldots \ldots \ldots \ldots \ldots \ldots$

3.4.2 Rhode Island Study $\ldots \ldots \ldots \ldots \ldots \ldots \ldots \ldots \ldots \ldots \ldots \ldots \ldots \ldots \ldots$

3.4.2.1 Horizontal Configuration for $345-\mathrm{kV}$ ac $\ldots \ldots \ldots \ldots \ldots . \ldots 36$

3.4.2.2 Davit Arm Configuration for $345-\mathrm{kV}$ ac ........... 38 


\section{CONTENTS (Cont.)}

3.4.2.3 Inverted-Delta Configuration for $345-\mathrm{kV}$ ac . . . . . . . 38

3.4.2.4 Split-Phase Configuration for $345-\mathrm{kV}$ ac . . . . . . . . . 38

3.4.2.5 Underground Delta Configuration for $345-\mathrm{kV}$ ac . . . . . . . 39

3.4.3 Washington State Study . . . . . . . . . . . . . . . 39

3.4.3.1 Horizontal Configuration for $230-\mathrm{kV}$ ac . . . . . . . . . 41

3.4.3.2 Davit Arm Configuration for $230-\mathrm{kV}$ ac . . . . . . . . . . 41

3.4.3.3 Delta Configuration for $230-\mathrm{kV}$ ac ................ 41

3.4.3.4 Split-Phase Configuration for $230-\mathrm{kV}$ ac $\ldots \ldots \ldots \ldots \ldots \ldots 42$

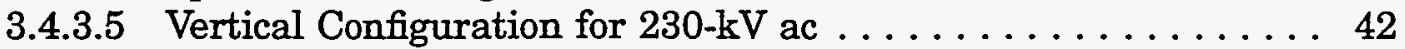

3.4.3.6 Underground Configuration for $230-\mathrm{kV}$ ac ........... 43

3.4.4 Bonneville Power Administration 500-kV Estimation Study . . . . . . . . 43

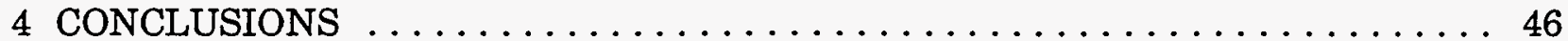

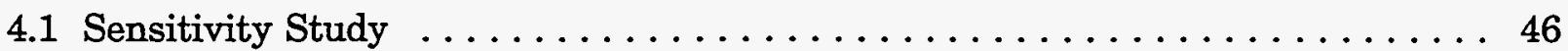

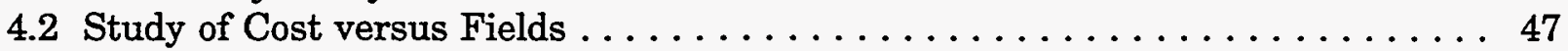

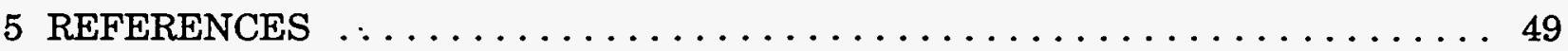

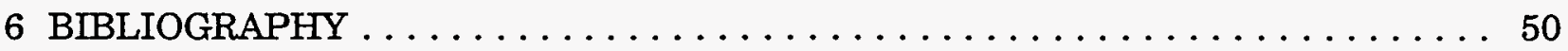

APPENDIX A: Sensitivity Calculations $\ldots \ldots \ldots \ldots \ldots \ldots \ldots \ldots \ldots \ldots \ldots \ldots \ldots \ldots$

APPENDIX B: Design and Construction Cost Data $\ldots \ldots \ldots \ldots \ldots \ldots \ldots$

\section{TABLES}

1 Calculated EMF Strengths and Sensitivities for $765-\mathrm{kV}$ ac

Horizontal Configuration . . . . . . . . . . . . . . . . . . 13

2 Calculated EMF Strengths and Sensitivities for $500-\mathrm{kV}$ ac Configurations . . . 16

3 Calculated EMF Strengths and Sensitivities for $345-\mathrm{kV}$ ac Configurations . . . . 21

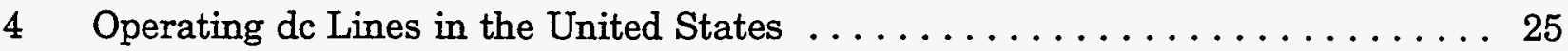

5 Calculated EMF Strengths and Sensitivities for $\pm 450-\mathrm{kV}$ dc

Horizontal Configuration . . . . . . . . . . . . . . . . . 28

6 Calculated EMF Strengths for Florida Base-Case and Proposed 230-kV Designs . . . . . . . . . . . . . . . . 30

7 Estimated Costs and Calculated EMF Strengths for 230-kV Designs from the Florida Study $\ldots \ldots \ldots \ldots \ldots \ldots \ldots \ldots \ldots \ldots \ldots \ldots \ldots$ 


\section{TABLES (Cont.)}

8 Calculated EMF Strengths for Florida Base-Case and Proposed 500-kV Designs . . . . . . . . . . . . . . . . . . 33

$9 \quad$ Estimated Costs and Calculated EMF Strengths for 500-kV Designs

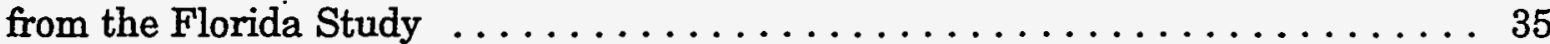

10 Calculated $345-\mathrm{kV}$ EMF Strengths from the Rhode Island Study . . . . . . . . 37

11 Calculated 230-kV EMF Strengths from the Washington State Study . . . . . . 40

12 Comparative Construction Costs and EMF Strengths for Two 500-kV Low-EMF Transmission Line Designs . . . . . . . . . . . 45

13 Sensitivity Analysis for Four $345-\mathrm{kV}$ Configurations $\ldots \ldots \ldots \ldots \ldots$

14 Estimated Costs and Calculated EMF Strengths for Five 345-kV Power Line Configurations from the Rhode Island Study . . . . . . . . . . 47

A.1 Calculated EMF Strengths and Sensitivities for $765-\mathrm{kV}$ ac Horizontal Configuration at $1,000 \mathrm{~A}$ per Phase $\ldots \ldots \ldots \ldots \ldots \ldots \ldots . \ldots \ldots$

A.2 Calculated EMF Strengths and Sensitivities for $500-\mathrm{kV}$ ac Horizontal Configuration at $1,000 \mathrm{~A}$ per Phase $\ldots \ldots \ldots \ldots \ldots \ldots \ldots$

A.3 Calculated EMF Strengths and Sensitivities for $500-\mathrm{kV}$ ac

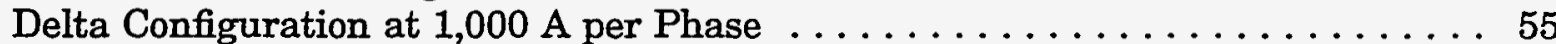

A.4 Calculated EMF Strengths and Sensitivities for $500-\mathrm{kV}$ ac Vertical Configuration at $1,000 \mathrm{~A}$ per Phase $\ldots \ldots \ldots \ldots \ldots \ldots \ldots 6$

A.5 Calculated EMF Strengths and Sensitivities for $500-\mathrm{kV}$ ac Davit Configuration at $1,000 \mathrm{~A}$ per Phase $\ldots \ldots \ldots \ldots \ldots \ldots \ldots . \ldots \ldots$

A.6 Calculated EMF Strengths and Sensitivities for $500-\mathrm{kV}$ ac Split-Phase Configuration at 1,000 A per Phase ................ 59

A.7 Calculated EMF Strengths and Sensitivities for $345-\mathrm{kV}$ ac Horizontal Configuration at $1,000 \mathrm{~A}$ per Phase $\ldots \ldots \ldots \ldots \ldots \ldots 6 . \ldots \ldots$

A.8 Calculated EMF Strengths and Sensitivities for $345-\mathrm{kV}$ ac Delta Configuration at 1,000 A per Phase $\ldots \ldots \ldots \ldots \ldots \ldots . \ldots 62$

A.9 Calculated EMF Strengths and Sensitivities for $345-\mathrm{kV}$ ac Davit Configuration at 1,000 A per Phase 


\section{TABLES (Cont.)}

A.10 Calculated EMF Strengths and Sensitivities for $345-\mathrm{kV}$ ac Split-Phase Configuration at 1,000 A per Phase . . . . . . . . . . . . 65

A.11 Calculated EMF Strengths and Sensitivities for $\pm 450-\mathrm{kV}$ dc Horizontal Configuration at $1,000 \mathrm{~A}$ per Phase $\ldots \ldots \ldots \ldots$

B.1 Calculated EMF Strengths versus Construction Cost Data from the Florida Study for $230-k V$ Transmission Lines . . . . . . . . . . . . . . 68

B.2 Calculated EMF Strengths versus Construction Cost Data from the Florida Study for $500-\mathrm{kV}$ Transmission Lines . . . . . . . . . . . . . 70

B.3 Calculated Magnetic Field versus Construction Cost Data from the Rhode Island Study for 345-kV Transmission Lines

B.4 Calculated EMF Strengths versus Construction Cost Data from the Washington State Study

\section{FIGURES}

1 States that Impose Limits on Electric or Magnetic Fields for the Construction of New Power Transmission Lines . . . . . . . . . . . . . . . . . . . 5

2 Tower for $500-\mathrm{kV}$ ac Split-Phase Configuration $\ldots \ldots \ldots \ldots \ldots \ldots$

3 Tower for $765-\mathrm{kV}$ ac Horizontal Configuration $\ldots \ldots \ldots \ldots \ldots \ldots$

4 Tower for $500-\mathrm{kV}$ ac Horizontal Configuration . . . . . . . . . . . . 15

5 Tower for $500-\mathrm{kV}$ ac Delta Configuration $\ldots \ldots \ldots \ldots \ldots \ldots \ldots$

6 Tower for $500-\mathrm{kV}$ ac Vertical Configuration $\ldots \ldots \ldots \ldots \ldots \ldots \ldots$

7 Tower for $500-\mathrm{kV}$ ac Davit Configuration $\ldots \ldots \ldots \ldots \ldots \ldots \ldots$

8 Tower for $345-\mathrm{kV}$ ac Horizontal Configuration . . . . . . . . . . . . . 19

9 Tower for $345-\mathrm{kV}$ ac Delta Configuration $\ldots \ldots \ldots \ldots \ldots \ldots \ldots \ldots \ldots$

10 Tower for $345-\mathrm{kV}$ ac Davit Configuration $\ldots \ldots \ldots \ldots \ldots \ldots \ldots \ldots \ldots$

11 Tower for $345-\mathrm{kV}$ ac Split-Phase Configuration $\ldots \ldots \ldots \ldots \ldots \ldots \ldots$ 


\section{FIGURES (Cont.)}

12 Tower for $\pm 450-\mathrm{kV}$ dc Horizontal Configuration $\ldots \ldots \ldots \ldots \ldots \ldots \ldots . \ldots \ldots$

13 Magnetic Fields Calculated with FIELDS 1.0 Program for the New England $\pm 450-\mathrm{kV}$ dc Transmission Line $\ldots \ldots \ldots \ldots \ldots \ldots . \ldots 25$

14 Calculated Total Electric Field near Ground for $\pm 400-\mathrm{kV}$ dc

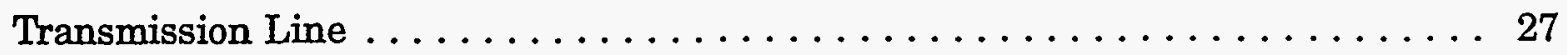

15 Presently Used Florida $230-\mathrm{kV}$ Vertical Design $\ldots \ldots \ldots \ldots \ldots \ldots \ldots \ldots$

16 Proposed Florida $230-k V$ Inverted-Delta Design $\ldots \ldots \ldots \ldots \ldots \ldots \ldots \ldots$

17 Proposed Florida $230-\mathrm{kV}$ Split-Phase Design $\ldots \ldots \ldots \ldots \ldots \ldots \ldots \ldots \ldots$

18 Existing Florida $500-\mathrm{kV}$ Vertical Design $\ldots \ldots \ldots \ldots \ldots \ldots \ldots \ldots \ldots$

19 Proposed Florida 500-kV Davit Design $\ldots \ldots \ldots \ldots \ldots \ldots \ldots \ldots \ldots \ldots$

20 Proposed Florida 500-kV Delta Design $\ldots \ldots \ldots \ldots \ldots \ldots \ldots \ldots \ldots \ldots \ldots \ldots \ldots$

21 Horizontal Configuration for $230-\mathrm{kV}$ ac $\ldots \ldots \ldots \ldots \ldots \ldots \ldots \ldots \ldots \ldots$

22 Davit Arm Configuration for $230-\mathrm{kV}$ ac $\ldots \ldots \ldots \ldots \ldots \ldots \ldots \ldots \ldots \ldots \ldots$

23 Delta Configuration for $230-\mathrm{kV}$ ac $\ldots \ldots \ldots \ldots \ldots \ldots \ldots \ldots \ldots \ldots \ldots \ldots \ldots \ldots$

24 Split-Phase Configuration for $230-\mathrm{kV}$ ac $\ldots \ldots \ldots \ldots \ldots \ldots \ldots \ldots \ldots \ldots \ldots$

25 Vertical Configuration for $230-\mathrm{kV}$ ac $\ldots \ldots \ldots \ldots \ldots \ldots \ldots \ldots \ldots \ldots \ldots \ldots \ldots$

26 Underground Configuration for $230-\mathrm{kV}$ ac $\ldots \ldots \ldots \ldots \ldots \ldots \ldots \ldots$ 


\section{ACKNOWLEDGMENTS}

The authors wish to express their appreciation to the following organizations for their assistance and contributions to the data acquisition effort undertaken for this study:

Baltimore Gas and Electric Co.

Commonwealth Associates

Commonwealth Edison Co.

Consolidated Edison, New York

Edison Electric Institute

Electric Power Research Institute

ElectroSciences, Inc.

Empire State Electric Energy Research Corp.

Energetics, Inc.

Florida Electric Power Cooperative

Gulf Power

IIT Research Institute

Missouri Public Service Co.

Northern States Power

Pacific Gas and Electric

Potomac Edison Co.

Power Technologies, Inc.

Washington State Department of Health

Wisconsin Electric Co. 


\section{NOTATION}

The following is a list of the acronyms, initialisms, and abbreviations (including units of measure) that appear in this document.

\section{ACRONYMS, INITIALISMS, AND ABBREVIATIONS}

ac

alternating current

ACSR

aluminum-core steel-reinforced

BPA

Bonneville Power Administration

dc direct current

DOE

EA

U.S. Department of Energy

EIS

ELF

EMF environmental assessment

EPRI environmental impact statement extremely low frequency

IEEE electric and magnetic field

NESC

Electric Power Research Institute

Institute of Electrical and Electronics Engineers, Inc.

National Electric Safety Code

\section{UNITS OF MEASURE}

$\begin{array}{ll}\mathrm{A} & \text { ampere(s) } \\ { }^{\circ} \mathrm{C} & \text { degree(s) Celsius } \\ \mathrm{dB}(\mathrm{A}) & \text { decibel(s) (A-weighted) } \\ \mathrm{ft} & \text { foot (feet) } \\ \mathrm{Hz} & \text { hertz } \\ \mathrm{in} . & \text { inch(es) } \\ \mathrm{kV} & \text { kilovolt(s) } \\ \mathrm{m} & \text { meter(s) } \\ \mathrm{MCM} & \text { kilo circular mil(s) } \\ \mathrm{mG} & \text { milligauss } \\ \mathrm{mi} & \text { mile(s) } \\ \mathrm{MW} & \text { megawatt(s) }\end{array}$




\title{
Electric Power High-Voltage Transmission Lines: \\ Design Options, Cost, and Electric and \\ Magnetic Field Levels
}

by

\author{
J.B. Stoffel, E.D. Pentecost, R.D. Roman, and P.A. Traczyk
}

\section{SUMMARY}

The aim of this report is to provide background information about (1) the electric and magnetic fields (EMFs) of high-voltage transmission lines at typical voltages and line configurations and (2) typical transmission line costs to assist preparers and reviewers of the section on alternatives in environmental documents. This report will give the reviewing individual a better appreciation of the factors affecting EMF strengths near high-voltage transmission lines and the approaches that might be used to reduce EMF impacts on humans and other biological species in the vicinity of high-voltage overhead or underground alternating-current (ac) or direct-current (dc) transmission lines.

The EMF strengths at distances from 0 to $\pm 200 \mathrm{ft}$ from the centerline were calculated for several configurations of high-voltage ac overhead transmission lines. The same calculations were made for a $345-\mathrm{kV}$ ac and a $230-\mathrm{kV}$ ac underground transmission line and for a $\pm 450-\mathrm{kV}$ dc overhead transmission line. The horizontal configuration was the only configuration of $765-\mathrm{kV}$ ac overhead line considered. For the $500-\mathrm{kV}$ ac overhead lines, the horizontal, delta, vertical, davit, and split-phase configurations were considered. For the $345-\mathrm{kV}$ ac overhead lines, the horizontal, delta, davit, and split-phase configurations were considered. For $230-\mathrm{kV}$ ac overhead lines, the vertical, inverted-delta, and split-phase configurations were considered.

The EMFs were then recalculated, first with the assumption that all conductor-to-conductor distances were decreased by $5 \mathrm{ft}$ and again with the assumption that all conductor-to-ground distances were increased by $5 \mathrm{ft}$. The differences between the basecase EMFs and the decreased conductor-to-conductor (compacted) and raised-line (heightened) EMFs were then divided by 5 to derive a compacting and heightening sensitivity factor (sensitivity) that can be used to qualify the reduction (or increase) in EMFs that should occur when high-voltage transmission line conductors are moved closer together or raised. The unit of measurement of the computed sensitivity is percent per foot. The compacting and height sensitivities were then compared and reported, together with a discussion of the meaning and significance of the compared values. 
Finally, estimated costs from other sources for the high-voltage transmission configurations and for the voltages that were considered in the calculations were collected; these estimated costs are presented and discussed so that the impact of using alternative strategies for reducing EMF strengths and the implications of implementing the strategies can be better appreciated. 


\section{INTRODUCTION}

\subsection{PURPOSE AND SCOPE}

The purposes of this study are (1) to describe the potential for reducing electric and magnetic field (EMF) levels or strengths near high-voltage transmission lines by changing the configuration of the lines, raising the lines, and reducing the spacing between conductors and (2) to discuss the cost implications of such changes for the Office of Fuels Programs of the U.S. Department of Energy (DOE). The data are intended for use in environmental analyses associated with Presidential Permit applications and by others who prepare environmental assessments (EAs) and environmental impact statements (EISs). The scope of this study extends to transmission line configurations for $60-\mathrm{Hz}$ (60 cycles per second) alternating-current (ac) transmission lines at 765, 500,345, and $230 \mathrm{kV}$ and for direct-current (dc) transmission lines at $\pm 450 \mathrm{kV}$.

\subsection{BACKGROUND}

Electric and magnetic fields occur naturally and as a consequence of human activity. Those created by human activity are produced by the use of electric and magnetic devices, including the generation, transmission, and application of electricity. Ambient levels of EMFs have increased dramatically as society has become more industrialized. Electric power system frequencies $(60 \mathrm{~Hz})$ are at the lower end of the range of frequencies of electromagnetic radiation and are sometimes referred to as extremely low frequencies (ELFs). Although considering the electric and magnetic forces together and collectively calling them electromagnetic fields is common, in the ELF range, the forces are two separate entities, both of which have unique interactions with living things. For power lines, electric fields are created whenever an electric voltage is applied to a conductor; whereas magnetic fields are created when current is running through a conductor (Waller and Geissinger 1992).

The environmental effects of power transmission lines have been under investigation for decades. Until recently, the research focused on efforts to protect the physical environment of the space used for transmission of power. In recent years, interest and concern about the potential health effects on biota (especially man) from exposure to EMFs has increased significantly because certain epidemiologic studies suggest a statistical association between exposure to EMFs and an increased risk of certain cancers.

A great deal of uncertainty surrounds the question of possible health effects from EMF exposure. Researchers are unsure about which aspect of exposure, if any, might be important in determining risk. The assumption has been made that frequency, magnetic field strength, electric field strength, currents induced in the body, time spent in the field, exposure to intermittent or switched fields, or other variables may be important. On the other hand, constant magnetic fields in the range of the earth's steady magnetic field of approximately $600 \mathrm{mG}$ are considered benign. To date, data from biological tests provide conflicting results. To counter some of this uncertainty, the concept of "prudent avoidance" 
has been introduced. This concept holds that individuals or society should take those measures to avoid magnetic field exposures that entail little or modest cost and that appear to be prudent, given the current level of scientific knowledge about health risks (Moore 1990).

The concerns for citizens living, working, or attending school close to power lines have compelled a number of state governments to consider or to adopt regulations or standards for EMFs. Seven states have imposed limits on electric or magnetic field strengths (or both) for the construction of new transmission lines within their borders (Figure 1). In other states, the need for regulation is still under consideration. Over the next few years, more states are likely to adopt EMF exposure standards, limits, or other measures as projected increased demand for electricity creates the need for new and upgraded transmission and distribution line capacity.

The DOE has been working with other federal agencies, states, researchers, the public, and the private sector to establish a comprehensive and coordinated National Electric and Magnetic Fields Research and Communication Program. Research activities include assessments of exposure and the development of options for field management and mitigation. In support of this broad-based program and to fulfill its own research needs regarding the health and safety effects of international electric transmission lines, the DOE Office of Fuels Programs has commissioned this study of the designs and costs of possible alternatives for EMF mitigation.

A utility must apply for and obtain a Presidential Permit before connecting a new transmission line to a foreign utility at the border of Canada or Mexico. The DOE Office of Fuels Programs reviews the utility applications for Presidential Permits. As part of its responsibility to comply with implementing procedures for the National Environmental Policy Act, an environmental impact analysis is conducted on the project. The impacts of each project and possible mitigative measures relative to construction and operation of the proposed transmission line system are evaluated before the Presidential Permit is issued. The practicality and effectiveness of various options for mitigation are compared with the costs of those options. The environmental review culminates in the preparation of an EA or EIS, in which the proposed project is described and discussed. 


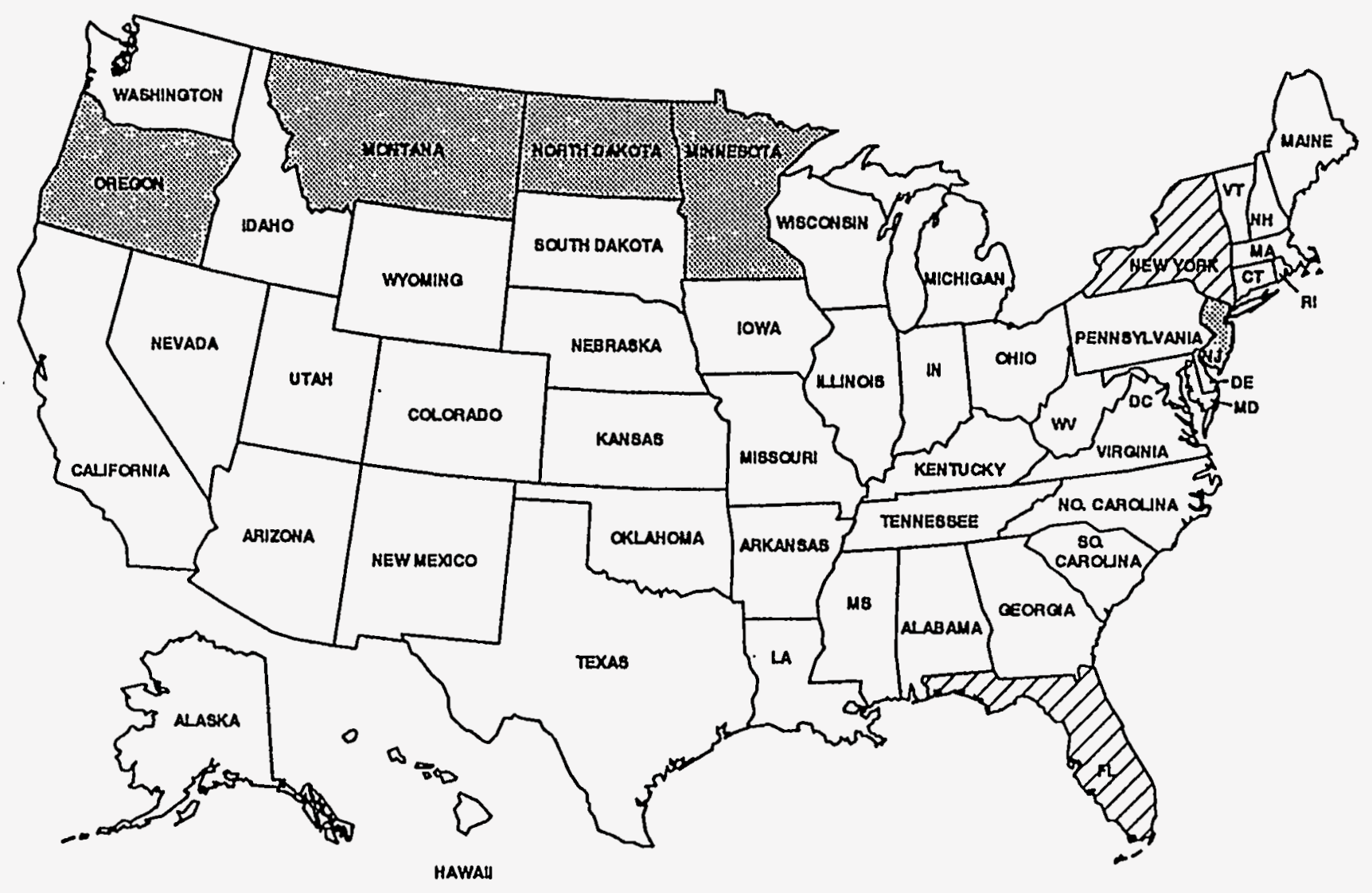

Standerds for olectric flolds

\section{8 magnetlo forde}

FIGURE 1 States that Impose Limits on Electric or Magnetic Fields for the Construction of New Power Transmission Lines 


\section{METHODS}

This study was done in three phases: (1) a search of the literature, (2) a sensitivity analysis, and (3) a cost comparison. Most of the time and effort were spent in the sensitivity analysis, which required a considerable number of calculations of EMF levels and sensitivity factors.

\subsection{SEARCH OF THE LITERATURE}

A search of the literature was conducted to obtain information on EMF mitigative strategies, particularly strategies for modifying transmission line design and for reducing EMF strengths. Utility industry research groups that provide technical support to utilities or public utility commissions (or both) and representative major utility companies were contacted to obtain more current information. The published results of several recent largescale research studies on EMF mitigation (Commonwealth Associates, Inc. 1992; Waller and Geissinger 1992; Oppel and Stewart 1993) were also reviewed. Data from these reports are presented in this report. These and other research studies were the basis for this comparison study of EMF reduction and costs for high-voltage transmission lines. Transmission line designs from the Transmission Line Reference Book (General Electric Co. 1982), published by the Electric Power Research Institute (EPRI), were used as the basis for the calculations performed in the sensitivity-analysis phase of the study.

\subsection{ANALYSIS OF SENSITIVITY}

The second part of the study consisted of an analysis to qualify the near-ground EMF strengths associated with several common high-voltage transmission line configurations at several common transmission line voltages and to calculate the changes of EMF strengths when the conductor-to-conductor (phase-to-phase) spacing is decreased or the conductor-toground (phase-to-ground) distance is increased.

The phase-to-phase analysis consisted of calculating both the EMF strengths of points located $3 \mathrm{ft}$ above the ground and on the centerline of the transmission line and at several distances within $\pm 200 \mathrm{ft}$ from the centerline. (The height of $3 \mathrm{ft}$ above ground was selected because it represents a reasonable height above ground for the middle body organs of a human adult and a reasonable height above ground for most organs and the heads of quadrupeds or the upper organs and heads of human children.) After calculating the field strengths for several common line configurations and several common transmission voltages a first time, recalculations were made for each voltage and configuration, except that all phase-to-phase distances were reduced (compacted) by $5 \mathrm{ft}$. Thus, two values of the electric field strengths and two values of the magnetic field strengths, a normal value and a compacted value, were derived for each point. By subtracting the two values and dividing by five times the normal value, factors called the compacting sensitivity were developed. These values have units of percent per foot and indicate the average change of EMF level caused 
by moving the lines closer together by $5 \mathrm{ft}$. The fact that the EMF levels would be increasingly attenuated as the lines get closer together indicates that the average compacting sensitivity value that is derived is different from what one can expect for smaller changes of phase spacing. Consequently, the compacting sensitivity merely qualifies, not quantifies, the changes of EMF levels.

The phase-to-ground analysis consisted of calculating both the EMF strengths of points located $3 \mathrm{ft}$ above the ground and on the centerline of the transmission line and points at several distances within $\pm 200 \mathrm{ft}$ from the centerline. (The height of $3 \mathrm{ft}$ above ground was selected for the same reasons noted previously.) After calculating the field strengths for several common line configurations and several common transmission voltages a first time, recalculations were made for each voltage and configuration, except that all phase-to-ground distances were increased (heightened) by $5 \mathrm{ft}$. Thus, two values of the electric field strengths and two values of the magnetic field strengths, a normal value and a compacted value, were derived for each point. By subtracting the two values and dividing by 5 times the normal value, factors called the height sensitivity were developed. These values have units of percent per foot and indicate the average change of EMF level caused by raising the lines by $5 \mathrm{ft}$. The fact that the EMF levels may not be attenuated in a linear manner as the lines are raised indicates that the derived value for height sensitivity may be different from what one would expect for smaller changes of conductor height. Consequently, the height sensitivity merely qualifies, not quantifies, the changes of EMF levels.

A positive value of either the compacting sensitivity or the height sensitivity indicates a decrease in EMF strength. Because of the numerous physical and environmental factors and the variability of conditions in the field, the calculated EMFs will probably be different from values derived by experiment or by actual field measurements (or by both). All EMF calculations were done by using the FIELDS 1.0 computer program developed by Southern California Edison Co.

\subsection{ANALYSIS OF COST VERSUS FIELDS}

The third part of this study focuses on the costs of mitigating EMFs. The analysis was performed by comparing estimated costs from other sources for various sized lines, configurations, and tower dimensions in Rhode Island, Florida, and Washington. 


\section{RESULTS}

\subsection{CONSIDERATIONS FOR PLANNING AND DESIGN}

Of primary importance in the planning and design of a power system is the need to provide continuous and reliable electric power, regardless of the power demand. Power systems are designed to incorporate a network or "grid" of interconnected substations. Generally, the more redundant the interconnection, the higher the reliability. To maintain reliability, transmission (and distribution) lines are designed to be able to carry more current than they are expected to carry on a daily basis (Waller and Geissinger 1992). Although reliability and continuity are of primary importance, a number of considerations that relate specifically to EMFs also go into the planning and design of power systems. The following discussion addresses some of these considerations.

In January 1992, P. Waller and L. Geissinger, members of the Electric Transmission Research Needs Task Force of the State of Washington, authored the report Electric and Magnetic Field Reduction: Research Needs. They concluded that planning and design for EMF reductions should include consideration of the number of lines, line voltage, conductor height, phase spacing, phase positioning, phase balance, conductor configuration, conductor size and bundling, underbuilding, right-of-way width, and utility practices. All of these design considerations are discussed in that report (Waller and Geissinger 1992).

\subsubsection{Number of Lines}

If existing portions of a network cannot reliably supply the anticipated power demand, the addition of one or more lines may be necessary to provide adequate reliability. The more lines serving an area, the more the current flow can be shared between lines, thus reducing the current flow in each line and the magnetic fields adjacent to each line.

\subsubsection{Voltage}

Voltage is probably the largest single factor affecting the strength of an electric field produced by a transmission line. Because the power delivered is proportional to the product of voltage and current, high voltages are used for power transmission to keep current-related line losses at economically viable levels. Similarly, magnetic fields (which are related to current level) are reduced when higher voltages and lower current transmission are used.

\subsubsection{Height of Conductors}

Generally, EMF strength is inversely related to the height of the transmission line conductors. As one moves away from the centerline, the increased distance will also reduce the EMFs; however, at points $120 \mathrm{ft}$ and $200 \mathrm{ft}$ from the centerline, data for some 
transmission line configurations show negative values (increasing EMFs) when conductor height is increased.

\subsubsection{Spacing of Phases (or Conductors)}

Alternating-current power is transmitted via one or more sets of three parallel conductors. The peak voltage of each conductor is, nominally, one-third or $120^{\circ}$ out of phase with the voltages of the other conductors. Consequently, ac power lines operate in a threephase mode. The earth acts as the second or return line for each phase. Direct-current power is also transmitted via three parallel conductors. The peak voltage of two of the conductors is constant but reversed. The third conductor acts as a return (ground) conductor. Consequently, dc power lines operate in a two-phase mode. Air provides the required insulation between conductors, as does air between the conductors and ground. Air and specially designed insulators provide insulation between the conductors and the towers. The higher the voltage, the larger the spacing and insulator length are required to be. All air spacing and insulators must be able to withstand voltage surges caused by lightning or switching, as well as allow sufficient insulating space for utility personnel to carry out their work safely during live-line maintenance activity. If placing all three phase conductors in the same physical space were electrically possible, the electric fields from the conductors would completely cancel each other out. Although close or compact placement reduces field strength, the ability of designers to achieve such reductions is limited because of the clearances required for insulation and the practice of performing live-line maintenance.

\subsubsection{Positioning of Phases}

Although the direction of currents in a single circuit line produces currents that oppose one another, the direction of currents in a double circuit line (such as the split-phase configuration shown in Figure 2) can be arranged so that currents oppose one another to an even greater extent. This arrangement results in significant reduction in magnetic field strength.

\subsubsection{Balance of Phases}

The ideal situation for minimum magnetic field strength is equal (balanced) phase currents. In practice, though, fluctuations in power demand between phases cause current differences in the individual phases, creating a condition known as phase unbalance. Although currents in each phase of most transmission lines are nearly balanced, the currents are never in perfect balance. 


\subsubsection{Spacing and Location of Conductors}

Conductors can be physically arranged in ways that will change the EMFs produced at a given current or voltage. Some of the more common configurations are defined later in this report.

\subsubsection{Size and Bundling of Conductors}

Conductor(s) must be large enough to carry the current without overheating, even during peak-load conditions. The choice of conductor diameter usually depends on a balancing of the installed cost of the line versus the cost of lost power over the lifetime of the line. Other considerations include the environmental and cost impacts caused by the corona effect (i.e., ionization of the air at the surface of a conductor caused by the voltage of the conductor, which produces related audible noise, radio frequency interference, and power losses). Corona effects decrease when the diameter of the conductor is increased. Corona effects can also be reduced by using two or more conductors per phase (bundling).

\subsubsection{Underbuilding}

Underbuilding is the practice of placing distribution lines or lower voltage transmission lines on the same towers beneath the primary transmission line. This practice can decrease magnetic fields at ground level, but the extent of the decrease is dependent on the voltages, currents, and phase arrangements of each circuit.

\subsubsection{Width of Right-of-Way}

The width of the right-of-way for power lines is typically determined by the cost of the land and the amount of space required for construction, operation, and maintenance of the line. Because EMF strength generally decreases with lateral distance from the centerline, the wider the right-of-way, the weaker the field strengths are at the edge. 


\subsubsection{Design Practices of Utilities}

Each utility employs design practices that are tailored to its particular needs. Regional variations in topography, weather, environmental factors, population density, service area size, and other factors all play a role in the design of a power transmission system.

\subsection{GENERAL METHODS FOR ELECTRIC AND MAGNETIC FIELD REDUCTION}

The primary methods for reducing EMFs from electric transmission lines are shielding and cancellation.

\subsubsection{Shielding}

Nearly any physical object will distort and reduce the electric field. Although shield wires are common above transmission lines to provide lightning protection, shield wires can also be used under power lines to reduce the electric field strength at ground level.

Shielding for magnetic fields requires that the fields be blocked by a shield made of iron or other magnetic material. Shielding against magnetic fields produced by power lines is very difficult and expensive to achieve because effective magnetic shields are large and heavy. A common misconception is that placing power lines underground achieves magnetic field reduction by earth shielding; however, such field reductions actually are caused by cancellation because the conductors are insulated and are placed very close together.

\subsubsection{Cancellation}

Cancellation in a double-circuit configuration (as shown in Figure 2) involves positioning out-of-phase conductors from each circuit close to each other so that the magnetic field from each conductor tends to cancel the field of the others. This cancellation becomes increasingly effective as one moves away from the tower's centerline perpendicular to the line.

Numerous tower designs and circuit configurations are employed by utilities for three-phase high-voltage power transmission. Different conductor spacing and phase arrangements usually produce very different magnetic field levels. Until recently, the choice of design was dependent primarily on such operational criteria as a line's capacitance and reactance or on such environmental criteria as aesthetics or corona effects (audible noise or radio frequency interference). 


\subsection{SPECIFIC OPTIONS FOR ELECTRIC AND MAGNETIC FIELD REDUCTION}

Specific design options that can both satisfy operational criteria and reduce EMFs are presented in the following sections. Different conductor configurations that will be discussed include horizontal, vertical, delta, davit, split-phase, and underground pipe configurations. The configurations, which will be defined as they are discussed, are compared with respect to cost, EMF strengths, and phase-spacing sensitivity.

\subsubsection{High-Voltage ac Transmission Lines}

From a design standpoint, 765-, 500-, and 345-kV transmission lines are considered to be extra-high-voltage or high-voltage transmission lines. The field strengths for the various design configurations that are reported here are the computer-calculated (not measured) field strengths. No minimum phase-to-phase distance is recommended in the National Electric Safety Code (NESC) (Institute of Electrical and Electronics Engineers, Inc. [IEEE] 1990); however, in the EPRI Transmission Line Reference Book, the normal high-voltage configurations are identified, and typical phase-to-phase and phase-to-ground distances are provided (General Electric Co. 1982). The minimum distances listed in the Transmission Line Reference Book were used to calculate the field strengths that are presented in the tables of this report.

\subsubsection{Configuration for $765-\mathrm{kV}$ ac Transmission Lines}

The only $765-\mathrm{kV}$ configuration described in the EPRI Transmission Line Reference Book (General Electric Co. 1982) is the horizontal configuration. A typical horizontal-configuration tower is shown in Figure 3. The $765-\mathrm{kV}$ voltage is advantageous for long-distance transmission because the higher voltage allows reduced current and minimizes line losses; however, the higher voltages need greater phase spacing to minimize corona effects. The horizontal configuration is generally used at $765 \mathrm{kV}$ because of the large distances required between the phases, because other designs require increased height, and because wind stress increases with tower height. A current of 1,000 A per phase was assumed for all $765-\mathrm{kV}$ calculations.

A review of $765-\mathrm{kV}$ transmission line designs in the EPRI Transmission Line Reference Book (General Electric Co. 1982) shows that existing systems use $40-54 \mathrm{ft}$ of minimum (point of maximum line sag between towers) phase-to-ground clearance. (The tower in Figure 3 shows typical dimensions for mountainous terrain.) This 40- to 54-ft distance is somewhat higher than the $35-\mathrm{ft}$ minimum ground clearance recommended by the NESC. The EPRI-listed phase-to-phase spacing for $765-\mathrm{kV}$ conductors is $40-50 \mathrm{ft}$.

Detailed data on the calculated field strengths and sensitivities for the $765-\mathrm{kV}$ horizontal configuration are presented in Table A.1 in Appendix A. The height sensitivity data in Table 1 indicate that increasing the line height is not very effective $(0.25 \% / \mathrm{ft})$ for reducing the magnetic field of a $765-\mathrm{kV}$ transmission line at a distance of $200 \mathrm{ft}$ from the centerline. Moreover, this design change would increase cost because the taller towers would require stronger and, therefore, more costly structures to withstand the increased wind stress. 


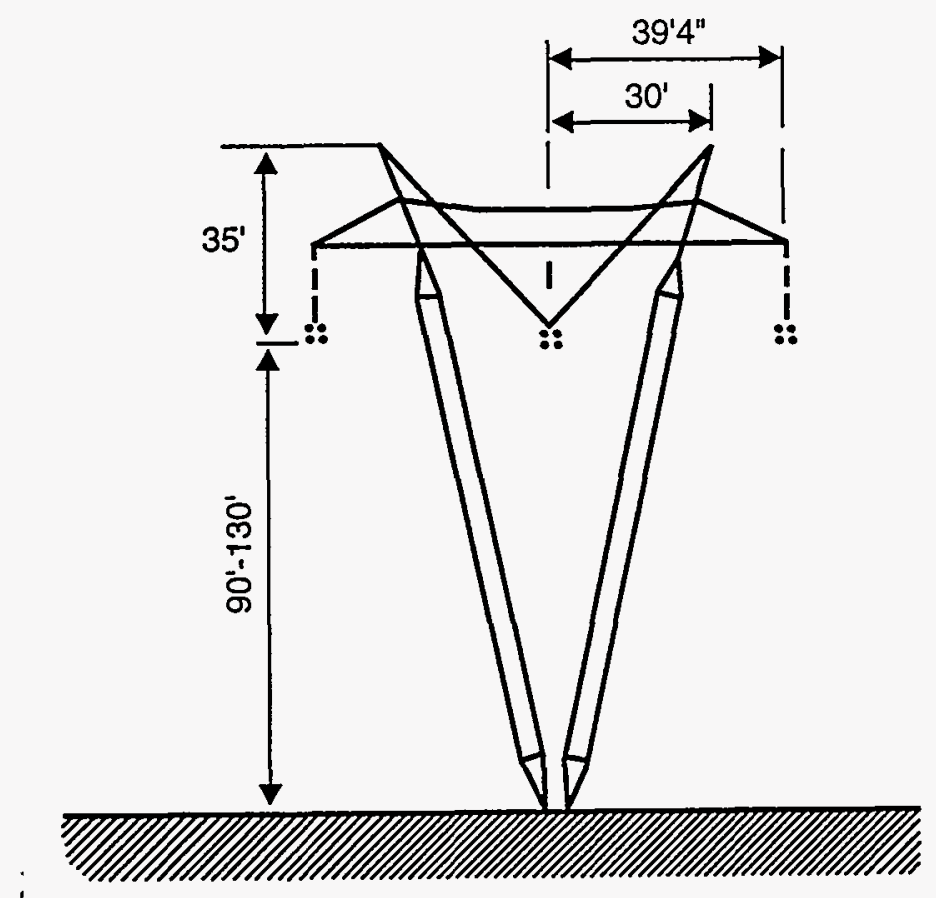

FIGURE 3 Tower for $765-\mathrm{kV}$ ac Horizontal Configuration

TABLE 1 Calculated EMF Strengths and Sensitivities for 765-kV ac Horizontal Configuration

\begin{tabular}{|c|c|c|c|c|c|c|}
\hline \multirow[b]{2}{*}{ Field } & \multicolumn{3}{|c|}{ Magnetic } & \multicolumn{3}{|c|}{ Electric } \\
\hline & $\begin{array}{l}\text { Field } \\
(\mathrm{mG})\end{array}$ & $\begin{array}{c}\text { Compacting } \\
\text { Sensitivity } \\
\text { (\%/ft) }\end{array}$ & $\begin{array}{c}\text { Height } \\
\text { Sensitivity } \\
\text { (\%/ft) }\end{array}$ & $\begin{array}{l}\text { Field } \\
(\mathrm{kV} / \mathrm{m})\end{array}$ & $\begin{array}{c}\text { Compacting } \\
\text { Sensitivity } \\
\text { (\%/ft) }\end{array}$ & $\begin{array}{c}\text { Height } \\
\text { Sensitivity } \\
(\% / f t)\end{array}$ \\
\hline Maximum & $\begin{array}{l}137 \text { at } \\
20 \mathrm{ft}^{\mathrm{a}}\end{array}$ & 0.82 & 2.6 & $\begin{array}{l}5.67 \text { at } \\
40 \mathrm{ft}^{\mathrm{a}}\end{array}$ & 0.51 & 3.2 \\
\hline $\begin{array}{l}120 \mathrm{ft} \text { from } \\
\text { centerline }^{\mathrm{b}}\end{array}$ & 30.9 & 2.9 & 0.69 & 1.23 & 2.8 & -0.58 \\
\hline $\begin{array}{l}200 \mathrm{ft} \text { from } \\
\text { centerline }\end{array}$ & 11.4 & 2.7 & 0.25 & 0.279 & 2.3 & -1.6 \\
\hline
\end{tabular}

a Distance from centerline.

b Centerline of tower. 
The data on compacting sensitivity in Table 1 indicate that, at $60 \mathrm{ft}$ or more from the centerline, decreasing the phase-to-phase distances (compaction) reduces both the electric and magnetic fields by about $3 \% / \mathrm{ft}$ because of the field cancellation effect. The decreased compacting sensitivity at distances less than $60 \mathrm{ft}$ can be attributed to the calculated point being closer to one of the phases and farther away from the other two phases.

Increasing the height of the lines reduces both the magnetic and electric field strengths under the lines because of the inverse proportionality of field strength to distance. Increasing the height has the opposite effect on the electric field strengths $(-1.5 \%)$ farther from the centerline ( $2120 \mathrm{ft}$ ) because the increased height of the conductors reduces the shielding effect of the adjacent conductor.

\subsubsection{Configurations for $500-\mathrm{kV}$ ac Transmission Lines}

Many different $500-\mathrm{kV}$ ac configurations exist. For the purposes of discussion, the following design configurations were chosen to be representative of the group:

- Horizontal,

- Delta,

- Vertical,

- Davit, and

- Split phase.

At the $500-\mathrm{kV}$ level, the NESC minimum (sag point) phase-to-ground clearance is $30 \mathrm{ft}$. The EPRI listing of existing systems contains examples that have a 28 -ft clearance for worst-case (maximum current and air temperature) conductor sag. The EPRI examples have phase-to-phase distances of $28-40 \mathrm{ft}$. For these sensitivity calculations, the minimum clearances were assumed to be $30 \mathrm{ft}$ for conductor to ground and $35 \mathrm{ft}$ between phases. A current of $1,000 \mathrm{~A}$ per phase was assumed for all $500-\mathrm{kV}$ calculations.

Horizontal Configuration for $500-\mathrm{kV}$ ac. For purposes of calculation, the ac horizontal design (Figure 4) was assumed to have two grounded shield wires $27 \mathrm{ft}$ above and $26 \mathrm{ft}$ on either side of the center transmission line. The 70- to 160-ft heights shown in Figure 4 are typical heights used in mountainous terrain.

Because minimal tower height is obtained with the horizontal-configuration tower, wind and line forces are minimized. Consequently, the horizontal configuration is generally least costly to build; however, the design has unbalanced line spacing (i.e., the phases are not equidistant from one another), so the horizontal-configuration tower has the highest EMFs. 
Table 2 lists the calculated magnetic field strength as $28.7 \mathrm{mG}$ at $120 \mathrm{ft}$ from the centerline and as $10.1 \mathrm{mG}$ at $200 \mathrm{ft}$. The compacting sensitivity at $200 \mathrm{ft}$ is $3.0 \% / \mathrm{ft}$.

At $200 \mathrm{ft}$ from the centerline, the calculated height sensitivity of $0.16 \% / \mathrm{ft}$ is only $5 \%$ of the compacting sensitivity. Clearly, raising the lines to reduce magnetic field strength is not as efficient as compacting the lines at $200 \mathrm{ft}$ from the centerline. On the other hand, the height sensitivity of $3.6 \% / \mathrm{ft}$ is 6 times $(600 \%)$ the compacting sensitivity at $20 \mathrm{ft}$ from the centerline.

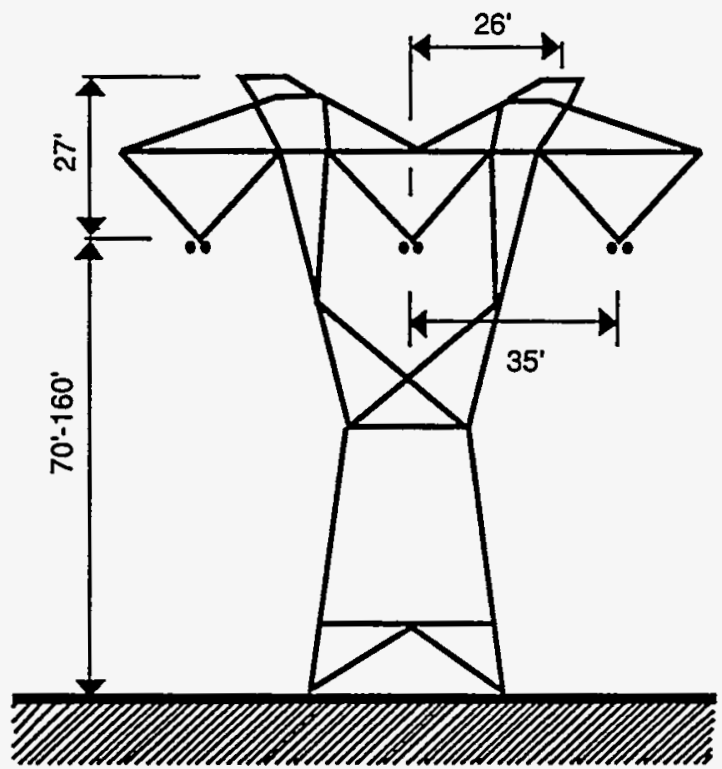

FIGURE 4 Tower for $500-\mathrm{kV}$ ac Horizontal Configuration

Delta Configuration for 500-kV ac. Figure 5 shows the delta-configuration tower. For purposes of calculation, the distance between phases $A$ and $C$ (the lower, horizontally aligned conductors) was assumed to be $30.7 \mathrm{ft}$, and the height of the $\mathrm{B}$ conductor above the $A$ and $C$ conductors was $29 \mathrm{ft}$. This arrangement results in a distance of $32.8 \mathrm{ft}$ between phases $A$ or $C$ and B. Shield wires were assumed to be $12 \mathrm{ft}$ on either side and $17 \mathrm{ft}$ above the top conductor. Again, Figure 5 shows typical ground-to-conductor heights of towers in mountainous terrain. The delta-configuration tower is somewhat higher than the horizontalconfiguration tower but is lower than the towers of the other configurations that will be discussed because the triangular spacing allows equal phase-to-phase distance in a smaller vertical height.

The calculated values of magnetic field strength are lower at all distances for the delta configuration than those for the horizontal configuration. For the delta configuration, the compacting sensitivity and height sensitivity at both $120 \mathrm{ft}$ and $200 \mathrm{ft}$ from the tower centerline are almost the same as those of the horizontal configuration; however, near the centerline, the compacting and height sensitivities of the delta configuration are about $320 \%$ and $130 \%$ more effective than the respective sensitivities for the horizontal configuration. The field can be reduced by $3.2 \%$ (at $200 \mathrm{ft}$ from the centerline) for each foot that the phases are compacted. The height sensitivities show the delta configuration to be a more effective design than the horizontal configuration for reducing magnetic fields near the centerline but show negligible improvement at the greater lateral distances.

The calculated electric field strengths for the $500-\mathrm{kV}$ delta configuration are below $6 \mathrm{kV} / \mathrm{m}$ at the tower centerline but drop to 0.27 and $0.09 \mathrm{kV} / \mathrm{m}$ at $120 \mathrm{ft}$ and $200 \mathrm{ft}$, respectively, from the centerline. Increasing conductor height has a similar effect on the electric field strength of both the delta and horizontal configurations (i.e., the field decreases near the centerline and increases at the outer distances). 
TABLE 2 Calculated EMF Strengths and Sensitivities for 500-kV ac Configurations

\begin{tabular}{|c|c|c|c|c|c|c|}
\hline \multirow[b]{2}{*}{$\begin{array}{l}\text { Configuration } \\
\text { and Field }\end{array}$} & \multicolumn{3}{|c|}{ Magnetic } & \multicolumn{3}{|c|}{ Electric } \\
\hline & $\begin{array}{l}\text { Field } \\
\text { (mG) }\end{array}$ & $\begin{array}{c}\text { Compacting } \\
\text { Sensitivity } \\
\text { (\%/ft) }\end{array}$ & $\begin{array}{c}\text { Height } \\
\text { Sensitivity } \\
\text { (\%/ft) }\end{array}$ & $\begin{array}{c}\text { Field } \\
(\mathrm{kV} / \mathrm{m})\end{array}$ & $\begin{array}{c}\text { Compacting } \\
\text { Sensitivity } \\
(\% / \mathrm{t})\end{array}$ & $\begin{array}{c}\text { Height } \\
\text { Sensitivity } \\
\text { (\%/ft) }\end{array}$ \\
\hline \multicolumn{7}{|l|}{ Horizontal } \\
\hline Maximum & 226 at $20 \mathrm{ft}^{\mathrm{a}}$ & 0.59 & 3.6 & 6.83 at $40 \mathrm{ft}^{\mathrm{a}}$ & 2.1 & 4.1 \\
\hline $\begin{array}{l}120 \text { ft from } \\
\text { centerline }^{b}\end{array}$ & 28.7 & 3.3 & 0.49 & 0.57 & 3.6 & -2.0 \\
\hline $\begin{array}{l}200 \mathrm{ft} \text { from } \\
\text { centerline }^{\mathrm{b}}\end{array}$ & 10.1 & 3.0 & 0.16 & 0.12 & 3.1 & -2.7 \\
\hline \multicolumn{7}{|l|}{ Delta } \\
\hline Maximum & 181 at $0 \mathrm{ft}^{\mathrm{a}}$ & 1.9 & 4.7 & 5.80 at $20 \mathrm{ft}^{\mathrm{a}}$ & 1.9 & 4.4 \\
\hline $\begin{array}{l}120 \mathrm{ft} \text { from } \\
\text { centerline }^{\mathrm{b}}\end{array}$ & 13.3 & 3.3 & 0.56 & 0.27 & 2.6 & -1.1 \\
\hline $\begin{array}{l}200 \text { ft from } \\
\text { centerline }^{b}\end{array}$ & 4.86 & 3.2 & 0.21 & 0.09 & 2.5 & -0.23 \\
\hline \multicolumn{7}{|l|}{ Vertical } \\
\hline Maximum & 152 at $0 \mathrm{ft}^{\mathrm{a}}$ & 1.3 & 4.2 & 6.53 at $0 \mathrm{ft}^{\mathrm{a}}$ & 0.94 & 4.0 \\
\hline $\begin{array}{l}120 \text { ft from } \\
\text { centerline }^{b}\end{array}$ & 18.7 & 2.7 & 0.58 & 0.26 & 0.78 & 3.3 \\
\hline $\begin{array}{l}200 \mathrm{ft} \text { from } \\
\text { centerline }^{\mathrm{b}}\end{array}$ & 7.75 & 3.0 & 0.26 & 0.16 & 2.1 & 1.3 \\
\hline \multicolumn{7}{|l|}{ Davit } \\
\hline Maximum & 152 at $0 \mathrm{ft}^{\mathrm{a}}$ & 0.72 & 4.04 & 5.75 at $20 \mathrm{ft}^{\mathrm{a}}$ & 1.7 & 4.5 \\
\hline $\begin{array}{l}120 \mathrm{ft} \text { from } \\
\text { centerline }^{\mathrm{b}}\end{array}$ & 14.1 & 2.4 & 0.47 & 0.37 & 2.9 & -0.05 \\
\hline $\begin{array}{l}200 \mathrm{ft} \text { from } \\
\text { centerline }^{b}\end{array}$ & 5.37 & 2.4 & 0.19 & 0.12 & 3.6 & -0.17 \\
\hline \multicolumn{7}{|l|}{ Split phase } \\
\hline Maximum & 158 at $0 \mathrm{ft}^{\mathrm{a}}$ & 2.5 & 5.1 & 5.12 at $20 \mathrm{ft}^{\mathrm{a}}$ & 2.7 & 4.9 \\
\hline $\begin{array}{l}120 \mathrm{ft} \text { from } \\
\text { centerline }^{\mathrm{b}}\end{array}$ & 8.60 & 5.3 & 0.87 & 0.27 & 5.1 & 1.5 \\
\hline $\begin{array}{l}200 \mathrm{ft} \text { from } \\
\text { centerline }^{b}\end{array}$ & 2.28 & 5.7 & 0.39 & 0.08 & 5.4 & 1.0 \\
\hline
\end{tabular}

a Distance from centerline.

b Centerline of tower. 


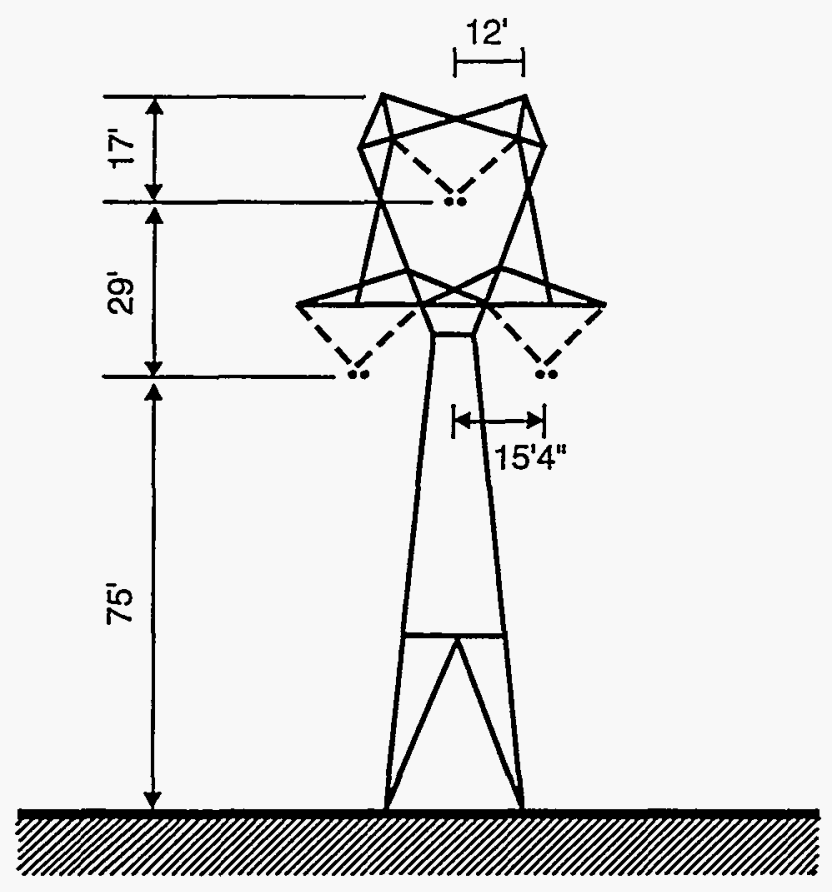

FIGURE 5 Tower for 500-kV ac Delta Configuration

Vertical Configuration for 500-kV ac. For purposes of calculation, the vertical configuration (Figure 6) has phase-to-phase spacings of $30 \mathrm{ft}$ and $60 \mathrm{ft}$ and a grounded shield wire at $33 \mathrm{ft}$ above the top conductor and displaced $9 \mathrm{ft}$ toward the tower. This design is the most costly tower design for $500-\mathrm{kV}$ lines because larger or stronger components would be needed to withstand increased wind and line load stresses caused by the taller towers.

Table 2 shows that the calculated magnetic field strengths for the vertical configuration are lower than those for the horizontal configuration but are higher, except for the fields directly under the line, than those for the other configurations. The sensitivities are comparable to those of the other configurations except for the split-phase configuration. The electric field strength is highest at the centerline and decreases as the distance to the centerline-increases.

Davit Configuration for $\mathbf{5 0 0 - k V}$ ac. The davit configuration (Figure 7 ) is basically a rotated delta configuration. For purposes of calculation, the vertical base of the triangle was $25 \mathrm{ft}$, and its horizontal measurement (height of the triangle) was about $35 \mathrm{ft}$. This configuration yielded phase-to-phase distances of $25 \mathrm{ft}$ or about $37.2 \mathrm{ft}$. Two grounded shield wires were assumed at $18 \mathrm{ft} 7 \mathrm{in}$. above the top conductor and displaced about $7 \mathrm{ft}$ toward the centerline from both the base conductors and the peak conductor.

The davit configuration is comparable in height to the delta configuration and therefore is subject to comparable wind and line loads on the tower. The cost of davit towers, therefore, should be comparable to the cost of delta towers. 
Calculations show that the maximum magnetic field strength for the davit configuration was reduced when compared with those of the horizontal and delta configurations, but the strength for the delta configuration at the $200-\mathrm{ft}$ distance from the centerline is about $10 \%$ lower than that for the davit configuration. Magnetic field strengths for the vertical configuration are comparable near the centerline but are higher than the field strengths for the davit configuration at greater distances from the centerline ( $44 \%$ higher at $200 \mathrm{ft}$ ).

The magnetic field compacting sensitivity for the davit configuration was $0.72 \% / \mathrm{ft}$ at the centerline, showed an increase to $3.1 \% / \mathrm{ft}$ at $60 \mathrm{ft}$, and then declined to $2.4 \% / \mathrm{ft}$ at both $120 \mathrm{ft}$ and $200 \mathrm{ft}$. The height sensitivity was $4.0 \% / \mathrm{ft}$ at the centerline, rose to $4.3 \% / \mathrm{ft}$ at $20 \mathrm{ft}$, and then steadily declined to $0.19 \% / \mathrm{ft}$ at $200 \mathrm{ft}$ from the centerline.

The electric field strengths, which were calculated to be less than $6 \mathrm{kV} / \mathrm{m}$ at all points from the centerline to $200 \mathrm{ft}$ from the centerline, are generally higher for the davit configuration than those for the delta configuration, except at the centerline.

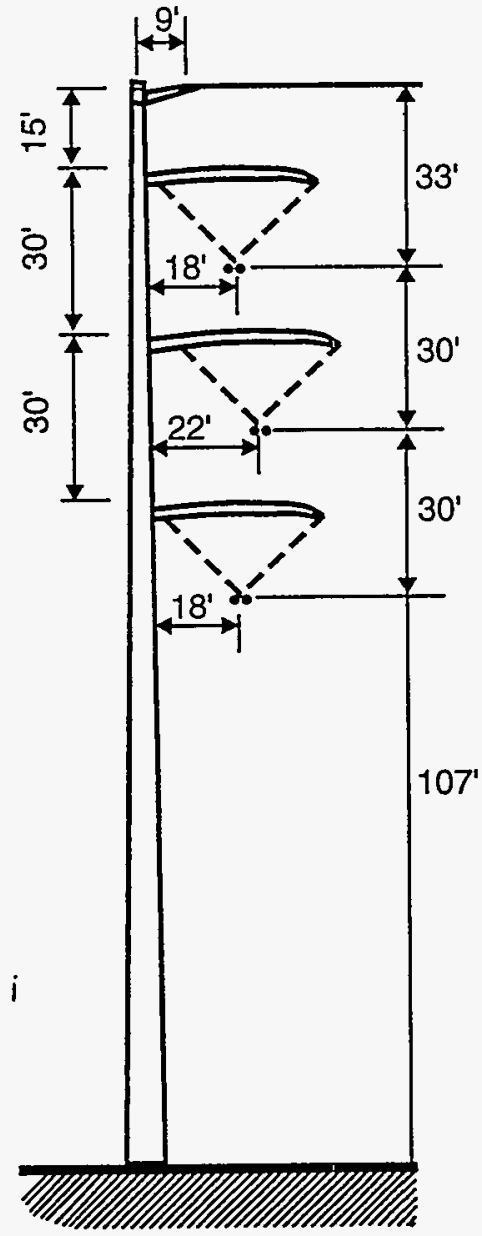

FIGURE 6 Tower for $500-k V$ ac Vertical Configuration

Split-Phase Configuration for $500-\mathbf{k V}$ ac. The split-phase configuration (Figure 2) contains two parallel circuits, one on each side of the tower. These circuits are in opposite sequence to each other (i.e., if one side has an A-B-C sequence from top to bottom, the other side will have a C-B-A sequence from top to bottom). For purposes of calculation, the spacing for the split-phase configuration was as shown in Figure 2. Because the currents were also assumed to be 1,000 A per phase, the transmission line power level is twice (200\%) that of the other configurations. One grounded shield wire was assumed at $35 \mathrm{ft}$ above the top conductors on the transmission line centerline. This configuration is the most costly because of both the tower height and the extra hardware and conductors required for the double circuits. 
The calculations yielded higher magnetic fields at the centerline for the split-phase configuration than those for the davit and vertical configurations but lower than those for the horizontal and delta configurations. The split-phase configuration also has the highest calculated compacting sensitivity (over $5 \% / \mathrm{ft}$ ) for distances greater than $100 \mathrm{ft}$. The electric fields compare favorably with those of the other configurations and were $3.3 \mathrm{kV} / \mathrm{m}$ at the centerline, increased to a maximum of $5.1 \mathrm{kV} / \mathrm{m}$ at $20 \mathrm{ft}$, and then gradually decreased to $0.08 \mathrm{kV} / \mathrm{m}$ at $200 \mathrm{ft}$.

\subsubsection{Configurations for $345-\mathrm{kV}$ ac Transmission Lines}

The study of the compacting and height sensitivities for $345-\mathrm{kV}$ transmission lines considered the following configurations from the EPRI Transmission Line Reference Book (General Electric Co. 1982):

- Horizontal,

- Delta,

- Davit, and

- Split phase.

For purposes of calculation, currents of $1,000 \mathrm{~A}$ per phase were assumed for all configurations.

Horizontal Configuration for 345-kV ac. For purposes of calculation, the horizontal configuration was assumed to be as shown in Figure 8. Two grounded shield wires were assumed at $18 \mathrm{ft}$ above and $18 \mathrm{ft}$ 7 in. on either side of the tower's centerline.

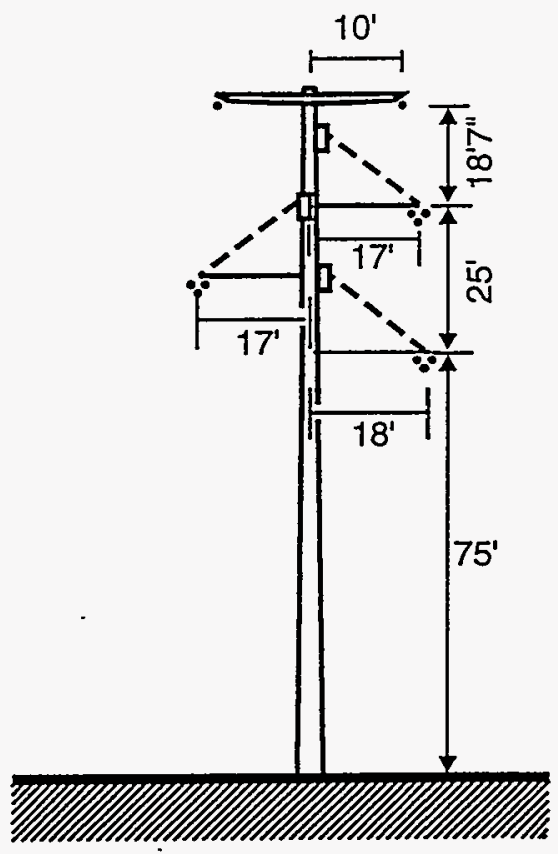

FIGURE 7 Tower for 500-kV ac Davit Configuration

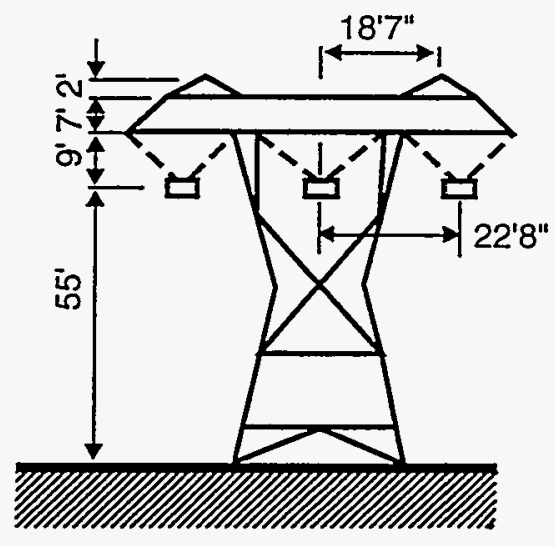

FIGURE 8 Tower for 345-kV ac Horizontal Configuration 
Table 3 lists the calculated magnetic field strengths of $17.7 \mathrm{mG}$ at a point $120 \mathrm{ft}$ from the transmission line centerline and $6.43 \mathrm{mG}$ at a distance of $200 \mathrm{ft}$. Calculations indicate that phase compacting can reduce the magnetic field by about $4.5 \% / \mathrm{ft}$ at distances of 120-200 $\mathrm{ft}$ from the centerline.

For the magnetic field, calculations show that, at a distance of $200 \mathrm{ft}$ from the centerline, the height sensitivity is $1 / 30$ th of the compacting sensitivity. Clearly, raising the lines to reduce the magnetic field is not very effective at $200 \mathrm{ft}$. On the other hand, raising the lines is about three times more effective than compacting the lines for reducing magnetic fields at the centerline of the transmission line.

Calculations for the horizontal configuration yield a maximum electric field of $3.65 \mathrm{kV} / \mathrm{m}$ at $20 \mathrm{ft}$ from the transmission line centerline and fields of $0.23 \mathrm{kV} / \mathrm{m}$ at $120 \mathrm{ft}$ from the centerline and $0.05 \mathrm{kV} / \mathrm{m}$ at $200 \mathrm{ft}$. The electric fields at $345 \mathrm{kV}$ are lower than those at $500 \mathrm{kV}$ because of the lower operating line voltage.

Compacting is reasonably effective for reducing the electric field at greater distances from the centerline; raising the line is not; however, at the more distant points, increasing the height has the effect of decreasing the cancellation effect among the three phases and causes an increase in the electric field. This increase is indicated by the negative sensitivities at 120 and $200 \mathrm{ft}$ from the centerline.

Delta Configuration for $345-\mathbf{k V}$ ac. For purposes of calculation, the delta configuration was assumed to be as shown in Figure 9, except the worst-case (sag point) phase-to-ground clearance was assumed to be $30 \mathrm{ft}$. Two grounded shield wires were assumed at $8 \mathrm{ft} 8 \mathrm{in}$. above the top conductor and $8 \mathrm{ft}$ on either side of the top conductor's centerline.

For magnetic fields, compacting the $345-\mathrm{kV}$ delta configuration is reasonably effective for reducing fields away from the transmission line centerline. In this case, the field can be reduced by $4.0 \% / \mathrm{ft}$ and $3.9 \% / \mathrm{ft}$ at 120 and $200 \mathrm{ft}$, respectively. Raising the power line is an effective method of reducing the magnetic field near the centerline but quite ineffective at 120 and $200 \mathrm{ft}$ from the centerline.

The electric field strengths are under $4 \mathrm{kV} / \mathrm{m}$ under the power lines and are less than $0.2 \mathrm{kV} / \mathrm{m}$ at distances greater than $120 \mathrm{ft}$ from the centerline. As with the horizontal configuration, increasing the lines' heights decreases the electric field near the centerline but increases the field at the longer distances from the centerline.

Davit Configuration for $\mathbf{3 4 5}-\mathrm{kV}$ ac. The davit configuration (Figure 10) is a rotated delta. For purposes of calculation, the vertical base of the davit configuration was assumed to be $23 \mathrm{ft}$ and its horizontal height $18 \mathrm{ft}$. One grounded shield wire was located on the centerline and $22 \mathrm{ft}$ above the topmost conductor. 
TABLE 3 Calculated EMF Strengths and Sensitivities for 345-kV ac Configurations

\begin{tabular}{|c|c|c|c|c|c|c|}
\hline \multirow[b]{2}{*}{$\begin{array}{l}\text { Configuration } \\
\text { and Field }\end{array}$} & \multicolumn{3}{|c|}{ Magnetic } & \multicolumn{3}{|c|}{ Electric } \\
\hline & $\begin{array}{l}\text { Field } \\
\text { (mG) }\end{array}$ & $\begin{array}{c}\text { Compacting } \\
\text { Sensitivity } \\
(\% / \mathrm{ft})\end{array}$ & $\begin{array}{l}\text { Height } \\
\text { Sensitivity } \\
\text { (\%/ft) }\end{array}$ & $\begin{array}{c}\text { Field } \\
(\mathrm{k} V / \mathrm{m})\end{array}$ & $\begin{array}{c}\text { Compacting } \\
\text { Sensitivity } \\
(\% / \mathrm{ft})\end{array}$ & $\begin{array}{c}\text { Height } \\
\text { Sensitivity } \\
\text { (\%/ft) }\end{array}$ \\
\hline \multicolumn{7}{|l|}{ Horizontal } \\
\hline Maximum & 207 at $0 \mathrm{ft}^{\mathrm{a}}$ & 1.38 & 3.83 & 3.65 at $20 \mathrm{ft}^{\mathrm{a}}$ & 1.03 & 4.85 \\
\hline $\begin{array}{l}120 \mathrm{ft} \text { from } \\
\text { centerline }^{\mathrm{b}}\end{array}$ & 17.7 & 4.6 & 0.43 & 0.23 & 4.4 & -2.3 \\
\hline $\begin{array}{l}200 \mathrm{ft} \text { from } \\
\text { centerline }\end{array}$ & 6.43 & 4.5 & 0.15 & 0.05 & 3.9 & -3.1 \\
\hline \multicolumn{7}{|l|}{ Delta } \\
\hline Maximum & 168 at $0 \mathrm{ft}^{\mathrm{a}}$ & 2.5 & 4.9 & 3.68 at $20 \mathrm{ft}^{\mathrm{a}}$ & 2.5 & 4.46 \\
\hline $\begin{array}{l}120 \mathrm{ft} \text { from } \\
\text { centerline }^{\mathrm{b}}\end{array}$ & 10.7 & 4.0 & 0.43 & 0.15 & 3.3 & -1.85 \\
\hline $\begin{array}{l}200 \mathrm{ft} \text { from } \\
\text { centerline }^{\mathrm{b}}\end{array}$ & 3.87 & 3.9 & 0.16 & 0.04 & 3.8 & -1.0 \\
\hline \multicolumn{7}{|l|}{ Davit } \\
\hline Maximum & 112 at $0 \mathrm{ft}^{\mathrm{a}}$ & 2.8 & 4.7 & 2.97 at $20 \mathrm{ft}^{\mathrm{a}}$ & 3.4 & 3.86 \\
\hline $\begin{array}{l}120 \mathrm{ft} \text { from } \\
\text { centerline }^{\mathrm{b}}\end{array}$ & 9.42 & 4.6 & 0.55 & 0.20 & 3.5 & 0.61 \\
\hline $\begin{array}{l}200 \mathrm{ft} \text { from } \\
\text { centerline }\end{array}$ & 3.43 & 4.6 & 0.21 & 0.07 & 3.8 & 0.27 \\
\hline \multicolumn{7}{|l|}{$\begin{array}{l}\text { Split phase } \\
\text { (at } 500 \mathrm{~A} \text { ) }\end{array}$} \\
\hline Maximum & 147 at $0 \mathrm{ft}^{\mathrm{a}}$ & 3.1 & 5.1 & 3.18 at $20 \mathrm{ft}^{\mathrm{a}}$ & 3.8 & 5.24 \\
\hline $\begin{array}{l}120 \mathrm{ft} \text { from } \\
\text { centerline }^{b}\end{array}$ & 6.94 & 5.6 & 0.77 & 0.13 & 3.6 & 0.15 \\
\hline $\begin{array}{l}200 \mathrm{ft} \text { from } \\
\text { centerline }^{b}\end{array}$ & 1.87 & 5.2 & 0.30 & 0.03 & 3.3 & 0 \\
\hline
\end{tabular}

a Distance from centerline.

b Centerline of tower. 


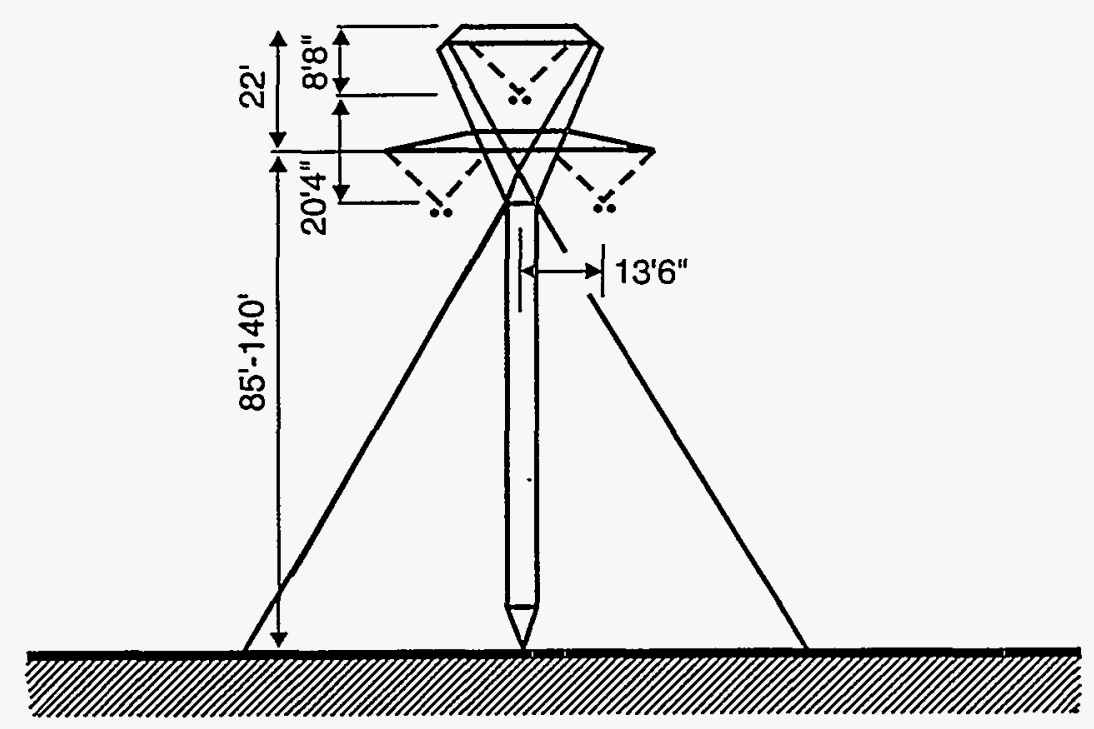

FIGURE 9 Tower for 345-kV ac Delta Configuration (shown with angled guy wires used to support tower)

The davit configuration is comparable in height to the delta configuration and therefore imposes the same wind and line loads on the tower. Consequently, the costs for the delta and davit configurations should be comparable.

Magnetic fields for the davit configuration were less at all distances from the centerline than those of the horizontal and delta configurations. The magnetic field compacting sensitivity was $2.8 \% / \mathrm{ft}$ at the centerline but increased to $4.6 \% / \mathrm{ft}$ at distances of $80-200 \mathrm{ft}$ from the centerline. The magnetic field height sensitivities show a maximum of $4.7 \% / \mathrm{ft}$ at the centerline but decreased with increasing distance from the centerline.

Compared with those for the delta configuration, the magnetic fields for the davit configuration are $33 \%$ lower at the centerline and are about the same at distances greater than $100 \mathrm{ft}$ from the centerline. The electric fields are less than $3 \mathrm{kV} / \mathrm{m}$ under the power line and are less than $1 \mathrm{kV} / \mathrm{m}$ at distances of $60 \mathrm{ft}$ and greater from the centerline.

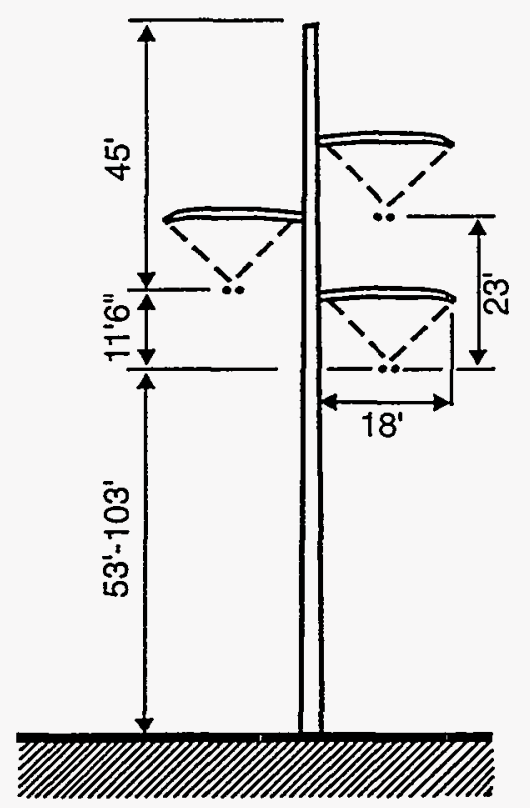

FIGURE 10 Tower for 345-kV ac Davit Configuration 
Split-Phase Configuration for $345-\mathbf{k V}$ ac. The split-phase design (Figure 11) contains two circuits, one on each side of the tower, and in opposite phase sequence to each other. Currents of 1,000 A per phase were assumed. Therefore, this configuration would also carry twice (200\%) the power of the other configurations. For purposes of calculation, the configuration spacing was assumed to be as shown in Figure 11. Two grounded shield wires were assumed at $24 \mathrm{ft}$ above the top conductor and $20 \mathrm{ft}$ on either side of the centerline. This configuration is the most costly of those considered because of the greater tower height and the double circuits.

For the split-phase configuration, the magnetic fields near the centerline are greater than those of the davit configuration but lower than those of the horizontal and delta configurations. At distances greater than $100 \mathrm{ft}$, the split-phase configuration has the lowest magnetic fields of the configurations that were considered. The split-phase configuration also has the highest magnetic field compacting sensitivities at all distances. The electric field strengths are comparable to those of the other configurations. The maximum electric field was $3.2 \mathrm{kV} / \mathrm{m}$ at $20 \mathrm{ft}$, but the field strengths dropped to less than $1 \mathrm{kV} / \mathrm{m}$ at distances of $60 \mathrm{ft}$ and greater from the centerline.

\subsubsection{Direct-Current Transmission Lines}

For purposes of calculation, the dc line consisted of a two-conductor tower ( \pm polarities) with a dedicated buried return conductor connected to each tower. Figure 12 shows a typical $\pm 450-\mathrm{kV}$ dc horizontal-configuration transmission tower.

Transmission of high-voltage dc power has received the attention of the electric utility industry since the 1930s but, because of technology limitations, did not become operational until 1954 in Sweden. The introduction of mercury-arc converters that could handle $100 \mathrm{kV}$ and 1,000 A in 1961 allowed a wider commercial application of dc lines in power transmission. From 1961 to 1975, the worldwide increase in the use of dc lines grew at the rate of $400 \mathrm{MW}$ per year. 
In 1989 , worldwide, $44,000 \mathrm{MW}$ of total installed dc transmission capacity was divided among 52 electrical power systems. Nineteen of these 52 systems were located in the United States and Canada. Table 4 lists the larger operating dc lines in the United States (Lee et al. 1993).

The following summary addresses design and cost considerations in planning $\mathrm{dc}$ transmission lines. Information supporting these conclusions was obtained from several references.

1. For distances over $250 \mathrm{mi}$, where intermediate tap-offs are not necessary, dc lines are more efficient than ac lines when both construction and operating costs are considered. The operating savings include the absence of the ac skin losses. These

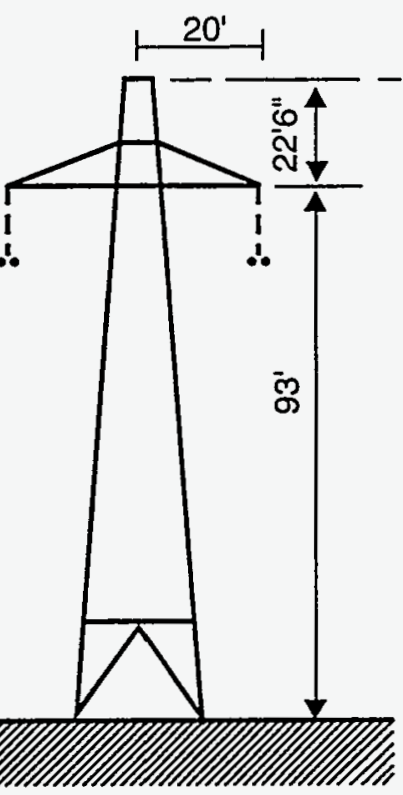

\section{FIGURE 12 Tower for $\pm 450-\mathrm{kV}$
de Horizontal Configuration} losses are caused by ac-induced forces that push the ac current to the conductor's surface (skin) and thereby reduce its effective area. Equivalent skin-effect resistance ranges from 5 to $10 \%$ of the conductor's dc resistance (Fink and Carroll 1969). Additionally, the dc line has only two conductors, instead of three; hence, power delivery is achieved with $67 \%$ of the cable resistance losses of the three-phase ac system.

The costs of ac-to-dc converters make short lines (or long lines with ac taps) too expensive for reasonable cost recovery. On the other hand, a long-distance ac line would require costly series compensation capacitors to transmit the power in a reasonably efficient manner. The estimated construction costs for a $\pm 450-\mathrm{kV}$ dc transmission line in northern New England, according to Oppel and Stewart (1993), are as follows:

a. A 2,000-MW transmission line costs about $\$ 1 \mathrm{million} / \mathrm{mi}$.

b. Each 2,000-MW ac-to-dc converter station costs about $\$ 200$ million.

2. Where concern exists about $60-\mathrm{Hz}$ magnetic fields, the dc line offers an absence of ac magnetic and electric fields. The dc line has no $60-\mathrm{Hz}$ fields, but static (dc) magnetic and electric fields are present. The earth also has a static magnetic field on the order of 500-600 mG. The magnetic field caused by a typical $\pm 450-\mathrm{kV}$ ac transmission line at $1,000 \mathrm{~A}$ in a worst-case scenario is equal to the earth's field and falls away to $2 \%(12 \mathrm{mG})$ of the earth's static field at $200 \mathrm{ft}$ from the center of the line. Figure 13 shows the magnetic fields calculated with the FIELDS 1.0 program (Southern California Edison Co.) for a typical $\pm 450-\mathrm{kV}$ transmission line at $1,000 \mathrm{~A}$. 
TABLE 4 Operating dc Lines in the United States

\begin{tabular}{lccc}
\hline \multicolumn{1}{c}{ Transmission Line } & $\begin{array}{c}\text { Year } \\
\text { Installed }\end{array}$ & $\begin{array}{c}\text { Voltage } \\
\text { Level (kV) }\end{array}$ & $\begin{array}{c}\text { Length } \\
(\mathrm{mi})\end{array}$ \\
\hline Square Butte & 1977 & \pm 250 & 465 \\
CU Project & 1979 & \pm 400 & 440 \\
Pacific Intertie upgrade & 1984 & \pm 500 & 850 \\
Intermountain & 1986 & \pm 500 & 490 \\
Comerford & 1986 & \pm 450 & 105 \\
New England & 1991 & \pm 450 & 930 \\
\hline
\end{tabular}

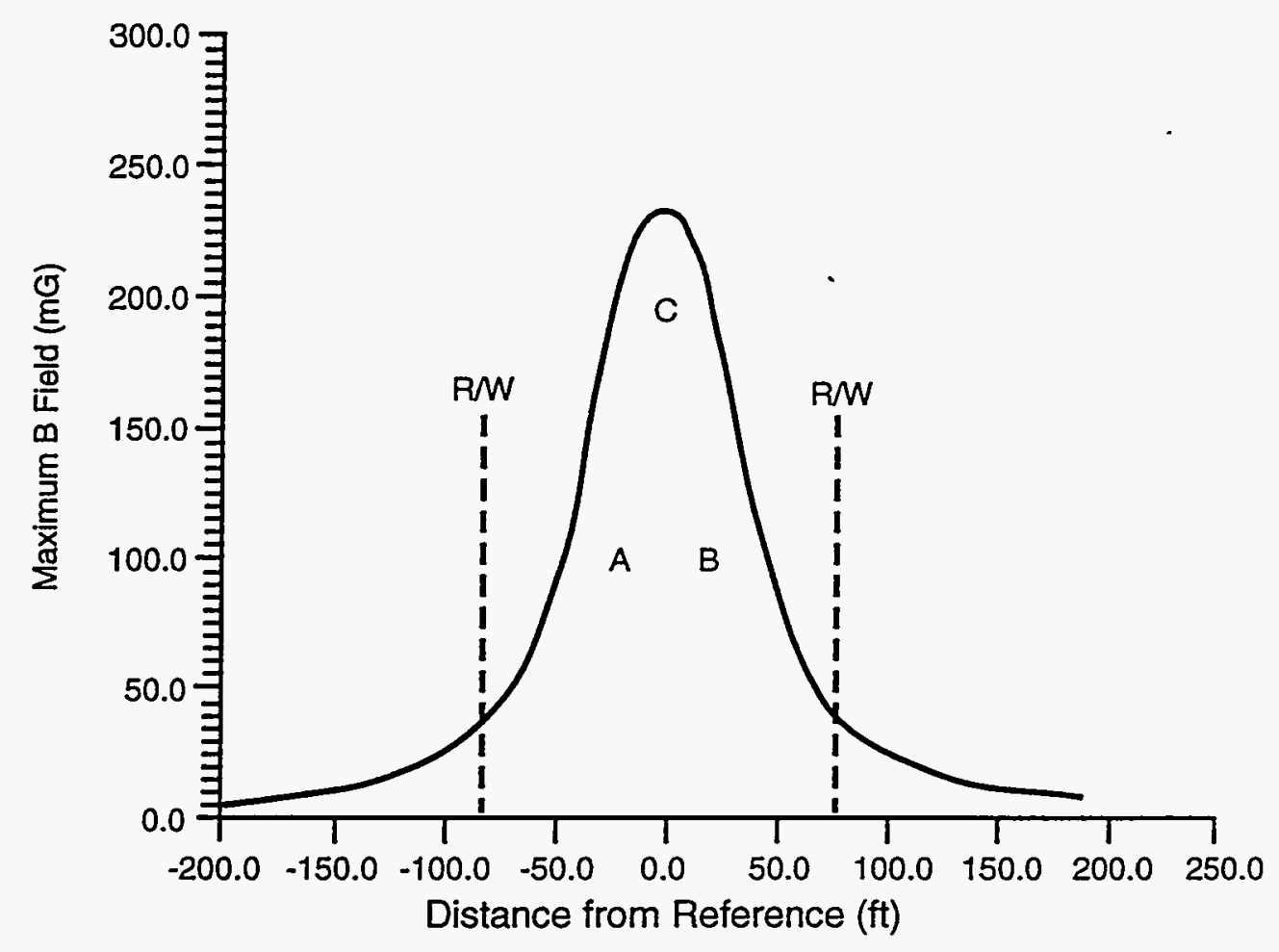

FIGURE 13 Magnetic Fields Calculated with FIELDS 1.0 Program for the New England $\mathbf{4 4 5 0 - k V ~ d c ~ T r a n s m i s s i o n ~ L i n e ~}$ 
3. For situations where controlling the power flow between ac systems is a priority, dc connection is an option. The dc power system is inherently more stable than an ac power system because of the ability of the dc power system to control the power flowing through it. In situations where two ac grids are not synchronous (i.e., weakly coupled and not exactly in phase), dc coupling may be the most practical solution. This solution was used for a New England (United States/Canadian) $\pm 450-\mathrm{kV}$ transmission line interconnection. System analysis indicated that an ac tie would be subject to large current flows if loading changed abruptly on either side of the border (Lee et al. 1993).

4. The electric field strengths from dc lines are, in general, higher than those from ac lines. Figure 14 shows the results of a study of electric fields below a $\pm 400-\mathrm{kV}$ dc line (Bracken et al. 1978). The results indicate that the electric field below the line is enhanced by the presence of ionized air and by atmospheric conditions.

Tests have demonstrated that current induced in a human body because of such dc field levels is far below the threshold of perception. The perception of dc-induced current is several orders of magnitude less than that for the ac-induced current from fields of equal strength.

5. Ionized air caused by dc transmission lines has been cited as a health concern. Air ions are molecules with either an extra electron (negative) or a missing electron (positive). Because of the high voltage, dc lines always produce corona discharges. Therefore, air ions are constantly being produced. Research (Lee et al. 1993) indicates that levels of production of ionized air fall within the lower range of values associated with causing subtle effects on biological systems. The effects of exposure to ionized air are very small and would be difficult to detect outside the laboratory because the symptoms of exposure are within the range of normal physiological and psychological symptoms caused by other environmental stresses.

6. Audible noise caused by the corona effect is a design consideration. Audible noise is greatest for ac transmission lines during heavy rain or wet conductor conditions. For dc lines, radio and audible noise generally decreases in wet weather, when ionization of the air around the conductor is the greatest. The intense ionization surrounds the conductor with a space charge region that reduces the electric field at the surface of the conductor. This region, in turn, suppresses the intensity of the corona pulses, and both the audible and radio noises are reduced. The level of audible noise produced by a dc line is 40 decibels (A-weighted) ( $\mathrm{dB}[\mathrm{A}]$ ), which is less than the $50 \mathrm{~dB}(\mathrm{~A})$ from an ac line (Oppel and Stewart 1993). 


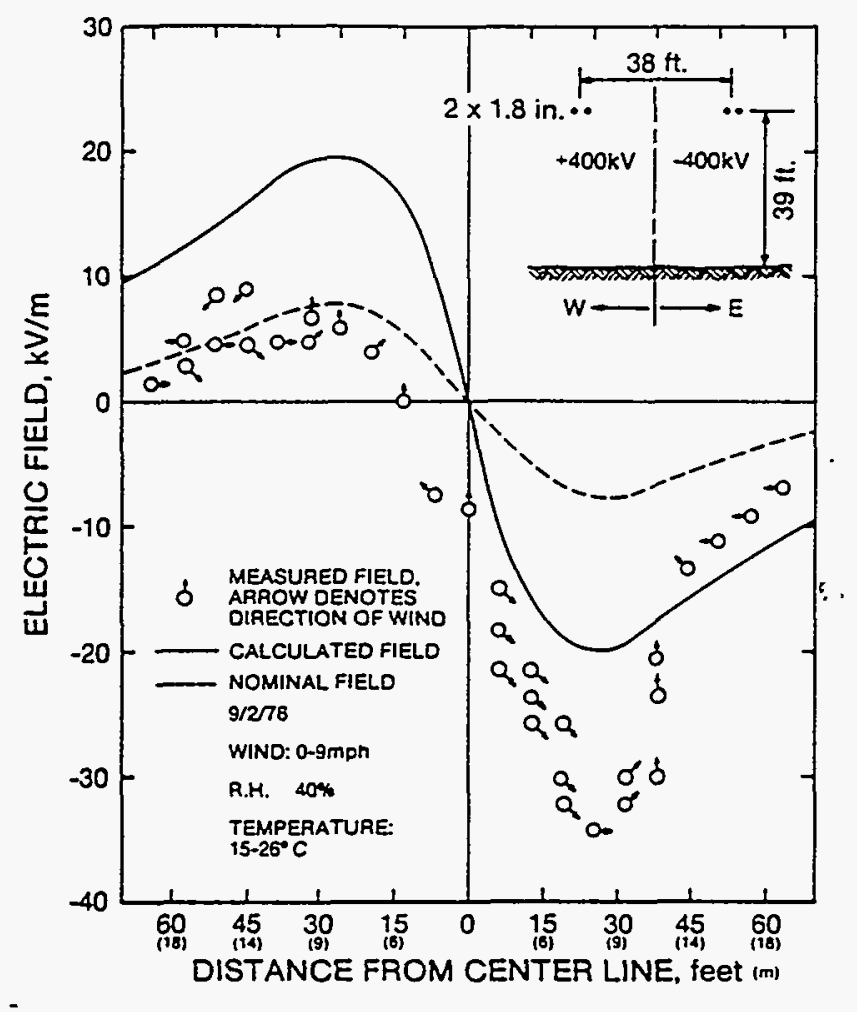

\section{FIGURE 14 Calculated Total Electric Field near Ground for $\pm 400-\mathrm{kV}$ dc Transmission Line $(\mathbf{R H}=$ relative humidity) (Source: Bracken et al. 1978 [@ IEEE])}

The EMF strengths at ground level for dc lines are dependent on the phase-to-phase distance and the phase-to-ground distance. Table 5 lists the calculated values of the fields at various points relative to the centerline of the transmission lines.

Although the dc magnetic field strength at the centerline is higher than those of the $500-\mathrm{kV}$ ac configurations, the dc field is constant (like the earth's magnetic field) and is less than $50 \%$ of the earth's magnetic field. Because of their constant nature and low strength relative to the earth's field, the magnetic fields from the dc lines are less controversial than the lower but fluctuating fields from ac transmission lines.

The calculated electric field is only provided here for completeness. Because of the effects of ionization, actual electric field strengths will vary substantially. This factor has been discussed previously. 
TABLE 5 Calculated EMF Strengths and Sensitivities for $\pm 450-k V ~ d c$ Horizontal Configuration

\begin{tabular}{|c|c|c|c|c|c|c|}
\hline \multirow[b]{2}{*}{ Field } & \multicolumn{3}{|c|}{ Magnetic } & \multicolumn{3}{|c|}{ Electric } \\
\hline & $\begin{array}{l}\text { Field } \\
\text { (mG) }\end{array}$ & $\begin{array}{c}\text { Compacting } \\
\text { Sensitivity } \\
(\% / f)\end{array}$ & $\begin{array}{c}\text { Height } \\
\text { Sensitivity } \\
\text { (\%oft) }\end{array}$ & $\begin{array}{c}\text { Field } \\
(\mathrm{kV} / \mathrm{m})\end{array}$ & $\begin{array}{c}\text { Compacting } \\
\text { Sensitivity } \\
\text { (\%/ft) }\end{array}$ & $\begin{array}{c}\text { Height } \\
\text { Sensitivity } \\
(\% / \mathrm{t})\end{array}$ \\
\hline Maximum $^{a}$ & 232 at $0 \mathrm{ft}^{\mathrm{b}}$ & 0.92 & 4.2 & 11 at $20 \mathrm{ft}^{\mathrm{b}}$ & 0.9 & 5 \\
\hline $\begin{array}{l}120 \mathrm{ft} \text { from } \\
\text { centerline }^{c}\end{array}$ & 18 & 2.6 & 0.41 & 0.66 & 2.4 & -2.2 \\
\hline $\begin{array}{l}200 \mathrm{ft} \text { from } \\
\text { centerline }^{c}\end{array}$ & 6.5 & 2.5 & 0.15 & 0.15 & 2.3 & -2.8 \\
\hline
\end{tabular}

\subsection{COSTS}

\subsubsection{Florida Study}

Power Technologies, Inc., conducted a study of $230-\mathrm{kV}$ and $500-\mathrm{kV}$ transmission systems (Oppel and Stewart 1993) for the Florida Department of Environmental Regulation "to analyze options and propose designs to further reduce the magnetic fields beyond the present Florida designs" (Oppel and Stewart 1993, chap. 1, p. 1). Specific information on the report is presented in Section B.1 of Appendix B. As a result of the study, two $230-\mathrm{kV}$ and two $500-\mathrm{kV}$ designs were proposed; and the designs and the costs of each design were presented.

\subsubsection{Proposed 230-kV Options}

Table B.1 in Appendix B lists the construction costs, magnetic fields, and electric fields for three $230-\mathrm{kV}$ transmission line configurations: vertical (base case), inverted delta, and split phase.

Base-Case 230-kV Vertical Configuration. Figure 15 shows the $230-\mathrm{kV}$ vertical transmission line (base case) configuration. The calculated field strengths for this configuration are listed in Table 6. The Florida study (Oppel and Stewart 1993) gives an estimate of $\$ 120,000 / \mathrm{mi}$ for the base-case design, which uses conductors with a 1.427-in. diameter. 


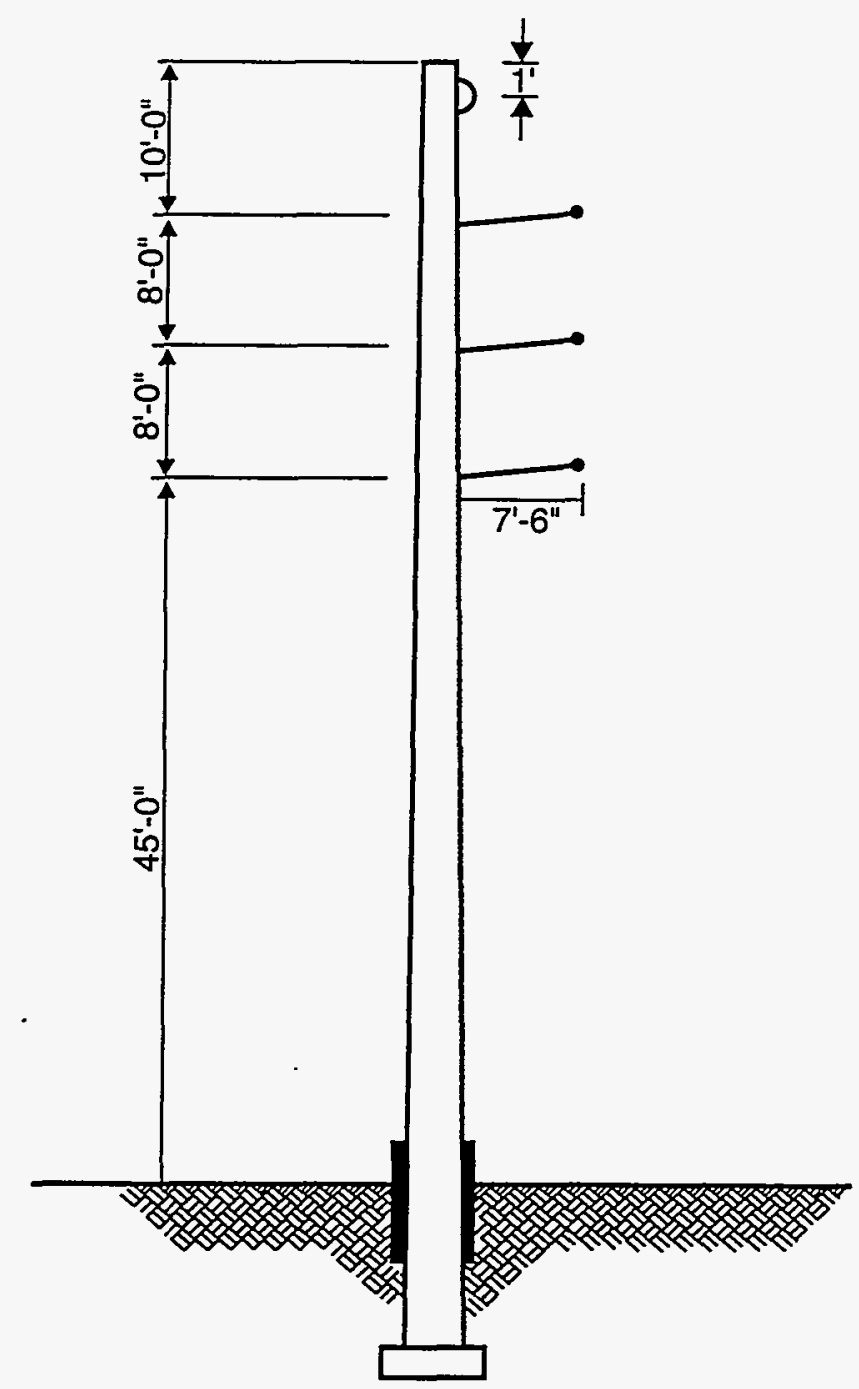

FIGURE 15 Presently Used Florida 230-kV Vertical Design

Proposed 230-kV Inverted-Delta Configuration. Figure 16 shows the proposed inverted-delta configuration. Table 6 also shows the calculated field strengths for the inverted-delta configuration.

Oppel and Stewart (1993) estimated a cost of $\$ 175,000 / \mathrm{mi}$ for this design, which uses 1.762-in.-diameter conductors. The larger conductor size was used to reduce corona problems associated with the smaller conductors.

Proposed 230-kV Split-Phase Configuration. Figure 17 shows the proposed $230-\mathrm{kV}$ split-phase design. Currents of $500 \mathrm{~A}$ per conductor were assumed to normalize the power levels of the split-phase configuration for comparison purposes. The results of the 230-kV split-phase calculations are also shown in Table 6. 
TABLE 6 Calculated EMF Strengths for Florida Base-Case and Proposed 230-kV Designs ${ }^{a}$

\begin{tabular}{|c|c|c|c|c|c|c|c|}
\hline \multirow[b]{2}{*}{ Configuration and Field } & \multicolumn{7}{|c|}{ Distance from Centerline of Tower $(\mathrm{ft})$} \\
\hline & 0 & 20 & 40 & 60 & 80 & 100 & 200 \\
\hline \multicolumn{8}{|l|}{ Vertical (base case) } \\
\hline Magnetic field (mG) & 79.0 & 57.3 & 32.1 & 18.7 & 11.9 & 8.06 & 2.2 \\
\hline Electric field (kV/m) & 1.88 & 0.9 & 0.15 & 0.061 & 0.079 & 0.07 & 0.03 \\
\hline \multicolumn{8}{|l|}{ Inverted delta } \\
\hline Magnetic field (mG) & 58.6 & 41.2 & 21.7 & 12.1 & 7.42 & 4.95 & 1.3 \\
\hline Electric field $(\mathrm{kV} / \mathrm{m})$ & 1.37 & 0.77 & 0.42 & 0.25 & 0.16 & 0.11 & 0.03 \\
\hline \multicolumn{8}{|l|}{ Split phase } \\
\hline Magnetic field (mG) & 33.5 & 22.2 & 9.84 & 4.5 & 2.3 & 1.3 & 0.19 \\
\hline Electric field (kV/m) & 0.99 & 1.03 & 0.33 & 0.06 & 0.02 & 0.02 & 0.01 \\
\hline
\end{tabular}

a Field strengths were calculated with FIELDS 1.0 program.

The estimated cost for the split-phase transmission line was $\$ 198,000 / \mathrm{mi}$. The cost includes the cost of six conductors of the same size and type used in the estimates for the vertical configuration. Because the cost of conductors is roughly proportional to their diameter, the assumption was made that the cost of the smaller conductors for the split-phase configuration could be reduced by $50 \%(\$ 56,000 \times 0.5=\$ 28,000)$. Hence, the conductor cost for the split-phase design was reduced by $\$ 28,000$ to $\$ 170,000 / \mathrm{mi}$. A comparison of the calculated field strengths at three different distances from the centerline and the cost per mile for the $230-\mathrm{kV}$ vertical, inverted-delta, and split-phase designs are presented in Table 7. Table 7 shows that the vertical design offers the lowest cost but the highest fields. Compared with the vertical design, the inverted-delta design reduces the magnetic fields by about $26 \%$, $38 \%$, and $36 \%$ at 0,100 , and $200 \mathrm{ft}$ from the centerline but increases the cost by $46 \%$.

The design with the lowest magnetic (and electric) fields is the split-phase design, which yielded $58 \%, 84 \%$, and $90 \%$ decreases in magnetic field strengths compared with the base case at 0,100 , and $200 \mathrm{ft}$, respectively, but at an increased cost. The cost of the inverted-delta design increased disproportionately because of the larger conductor size that was selected to control the corona expected from this design.

Alternately, the assumption was made that the split-phase design could use smaller conductors (because of the 500-A phase current) without increasing corona effects. These two 


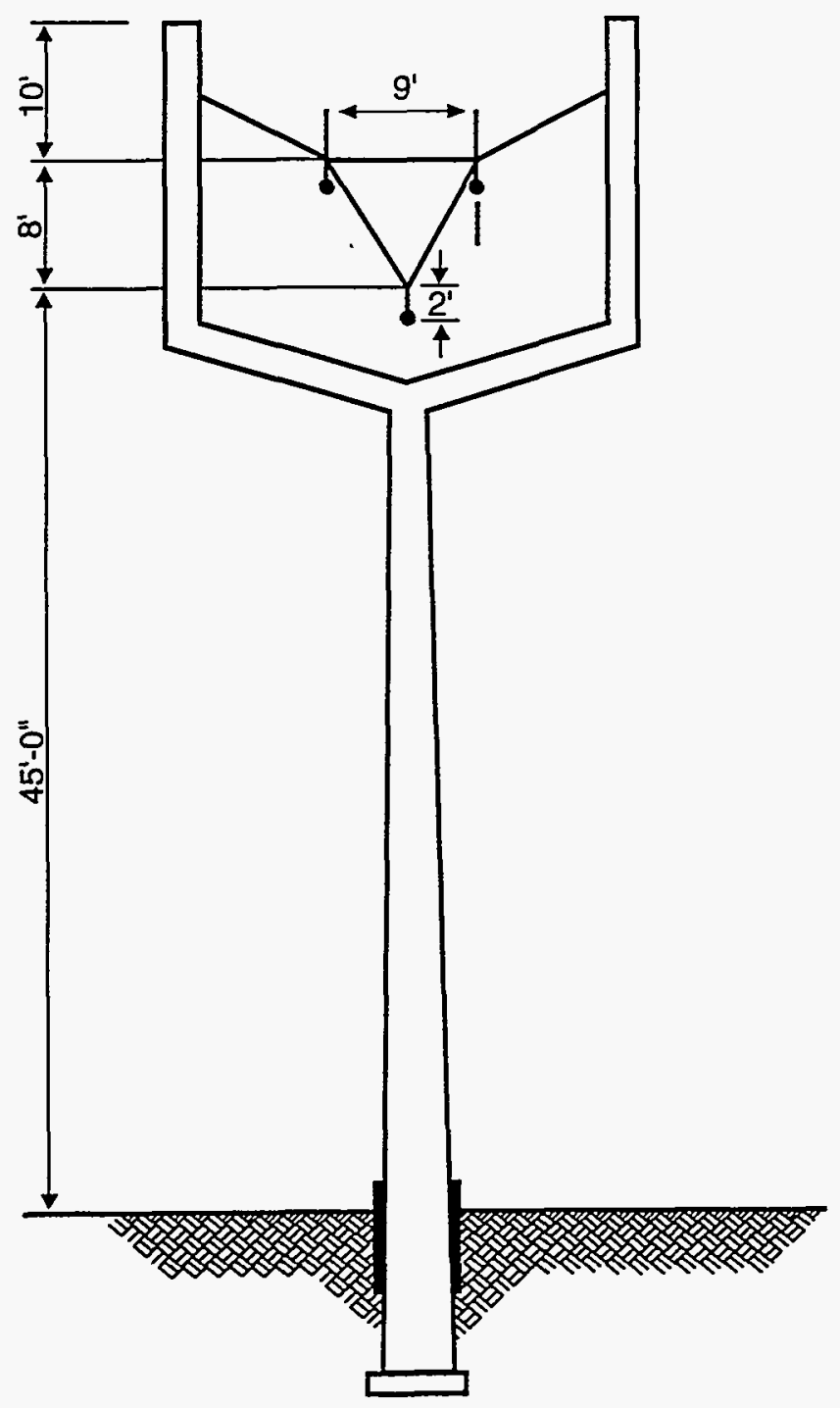

FIGURE 16 Proposed Florida 230-kV Inverted-Delta Design

considerations and the extra cost associated with the nonstandard inverted-delta design caused the split-phase design to be less costly than the inverted-delta design. The low EMFs show that the split-phase design is extremely effective in reducing magnetic fields. Although the other configurations exhibit relatively low electric field strengths at all distances, the split-phase design yielded the lowest electric field strength.

\subsubsection{Proposed 500-kV Options}

Data on one existing and two proposed $500-\mathrm{kV}$ designs from the Florida study are shown in Table B.2 in Appendix B. The designs are vertical (base case), davit, and delta configurations. The FIELDS 1.0 program was run for each of these designs to provide a comparison of field strengths, as well as costs. 


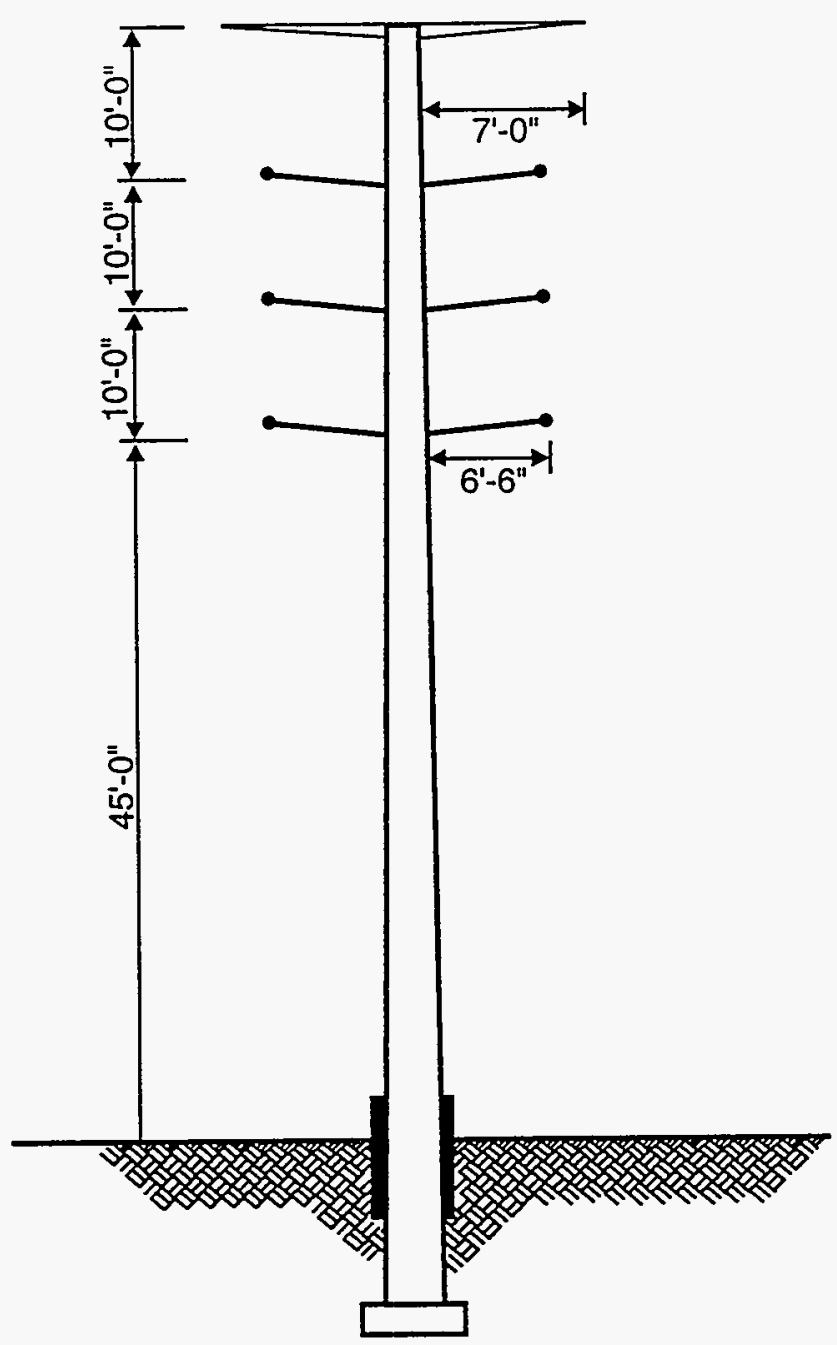

FIGURE 17 Proposed Florida 230-kV

Split-Phase Design

Base-Case 500-kV Vertical Configuration. Figure 18 shows the existing 500-kV vertical configuration. One shield wire on the centerline at a height of $37 \mathrm{ft}$ above the top conductor was assumed.

With the exception of directly under the line $(0 \mathrm{ft}$ ), the magnetic field for the base case is lower at distances up to $60 \mathrm{ft}$ from the centerline (Table 8) when compared with those of the other two alternatives but is higher at distances greater than $60 \mathrm{ft}$. The field is less than $10 \mathrm{mG}$ at the $200-\mathrm{ft}$ distance and decreases rapidly beyond this distance. The estimated construction cost for this design (Table 9 ) is $\$ 534,000 / \mathrm{mi}$.

Proposed 500-kV Davit Configuration. Figure 19 shows the proposed 500-kV davit configuration. The shield wires are $30 \mathrm{ft}$ above the top conductor and $16 \mathrm{ft}$ on either side of the centerline. 
TABLE 7 Estimated Costs and Calculated EMF Strengths for 230-kV Designs from the Florida Study

\begin{tabular}{|c|c|c|c|c|c|}
\hline \multirow[b]{2}{*}{ Design } & \multirow[b]{2}{*}{$\begin{array}{l}\text { Cost per } \\
\text { Mile }^{\mathbf{a}}\end{array}$} & \multicolumn{4}{|c|}{ Field and Location Relative to Centerline } \\
\hline & & Field & $\underset{\text { Field }^{\mathrm{b}}}{\text { Maximum }}$ & $100 \mathrm{ft}^{\mathrm{b}}$ & $200 \mathrm{ft}^{\mathrm{b}}$ \\
\hline Vertical & $\$ 120,000$ & $\begin{array}{l}\text { Magnetic }(\mathrm{mG}) \\
\text { Electric }(\mathrm{kV} / \mathrm{m})\end{array}$ & $\begin{array}{l}79.0 \text { at } 0 \mathrm{ft} \\
1.88 \text { at } 0 \mathrm{ft}\end{array}$ & $\begin{array}{l}8.06 \\
0.07\end{array}$ & $\begin{array}{l}2.20 \\
0.03\end{array}$ \\
\hline $\begin{array}{l}\text { Inverted } \\
\text { delta }\end{array}$ & $\$ 175,000$ & $\begin{array}{l}\text { Magnetic }(\mathrm{mG}) \\
\text { Electric }(\mathrm{kV} / \mathrm{m})\end{array}$ & $\begin{array}{l}58.6 \text { at } 0 \mathrm{ft} \\
1.37 \text { at } 0 \mathrm{ft}\end{array}$ & $\begin{array}{l}4.95 \\
0.11\end{array}$ & $\begin{array}{l}1.3 \\
0.03\end{array}$ \\
\hline $\begin{array}{l}\text { Split } \\
\text { phase }\end{array}$ & $\$ 170,000$ & $\begin{array}{l}\text { Magnetic }(\mathrm{mG}) \\
\text { Electric }(\mathrm{kV} / \mathrm{m})\end{array}$ & $\begin{array}{l}33.5 \text { at } 0 \mathrm{ft} \\
1.17 \text { at } 10 \mathrm{ft}\end{array}$ & $\begin{array}{l}1.3 \\
0.02\end{array}$ & $\begin{array}{l}0.19 \\
0.01\end{array}$ \\
\hline
\end{tabular}

a Source: Oppel and Stewart (1993).

b Calculated with FIELDS 1.0 program.

TABLE 8 Calculated EMF Strengths for Florida Base-Case and Proposed 500-kV Designs ${ }^{a}$

\begin{tabular}{lccccccc}
\hline & \multicolumn{7}{c}{ Distance from Centerline of Tower (ft) } \\
\cline { 2 - 7 } Configuration and Field & 0 & 20 & 40 & 60 & 80 & 100 & 200 \\
\hline Vertical & & & & & & & \\
Magnetic field (mG) & 158 & 123 & 79.7 & 53.0 & 37.1 & 27.1 & 8.65 \\
Electric field (kV/m) & 6.76 & 4.02 & 1.40 & 0.43 & 0.21 & 0.22 & 0.13 \\
Davit & & & & & & & \\
Magnetic field (mG) & 141 & 145 & 95.4 & 57.0 & 36.1 & 24.3 & 6.25 \\
Electric field (kV/m) & 3.86 & 6.19 & 3.34 & 1.37 & 0.75 & 0.52 & 0.15 \\
Delta & & & & & & & \\
Magnetic field (mG) & 185 & 156 & 93.8 & 93.9 & 34.9 & 23.8 & 6.61 \\
Electric field $(\mathrm{kV} / \mathrm{m})$ & 4.23 & 6.15 & 3.63 & 1.57 & 0.76 & 0.44 & 0.12 \\
\hline
\end{tabular}

a Field strengths were calculated with FIELDS 1.0 program. 


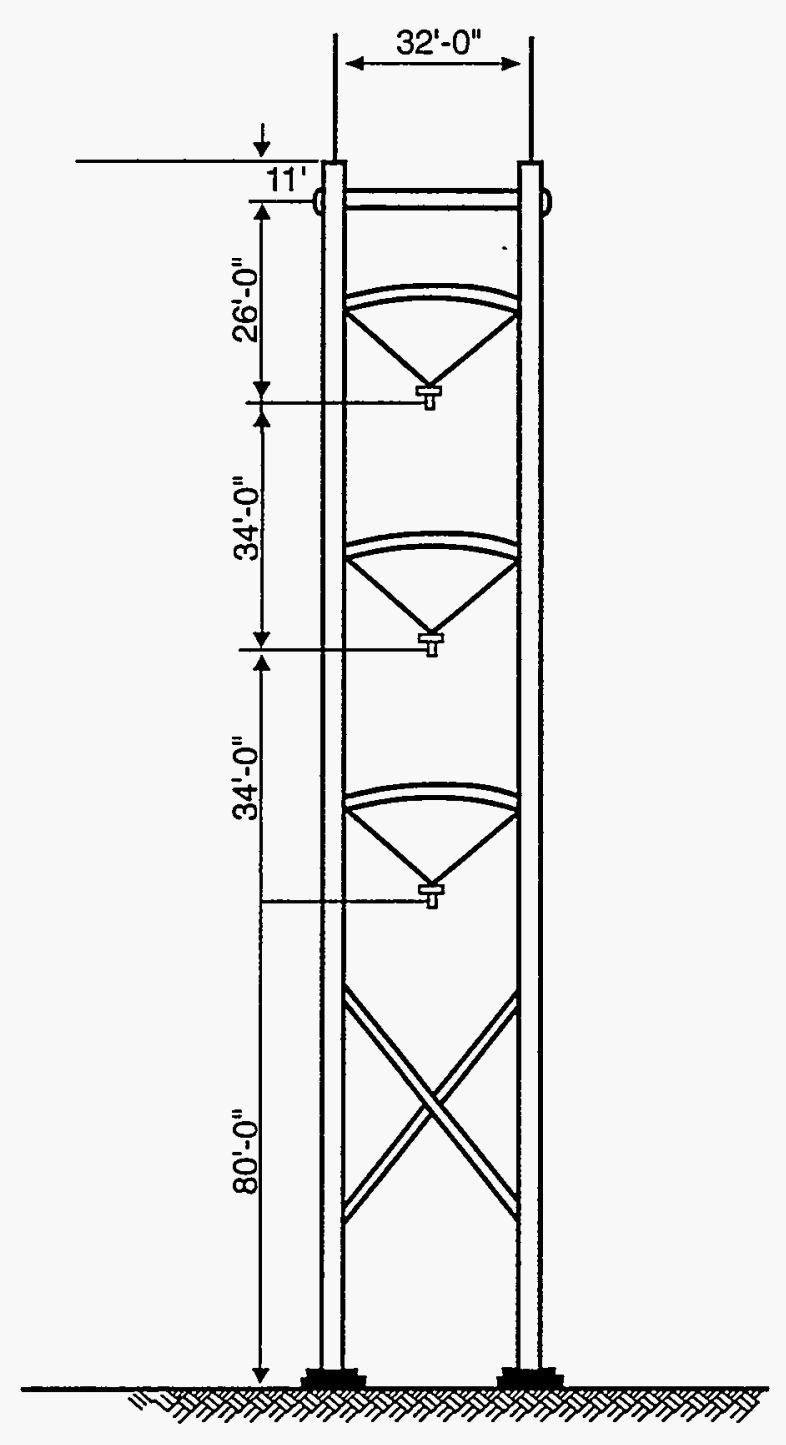

FIGURE 18 Existing Florida 500-kV Vertical Design

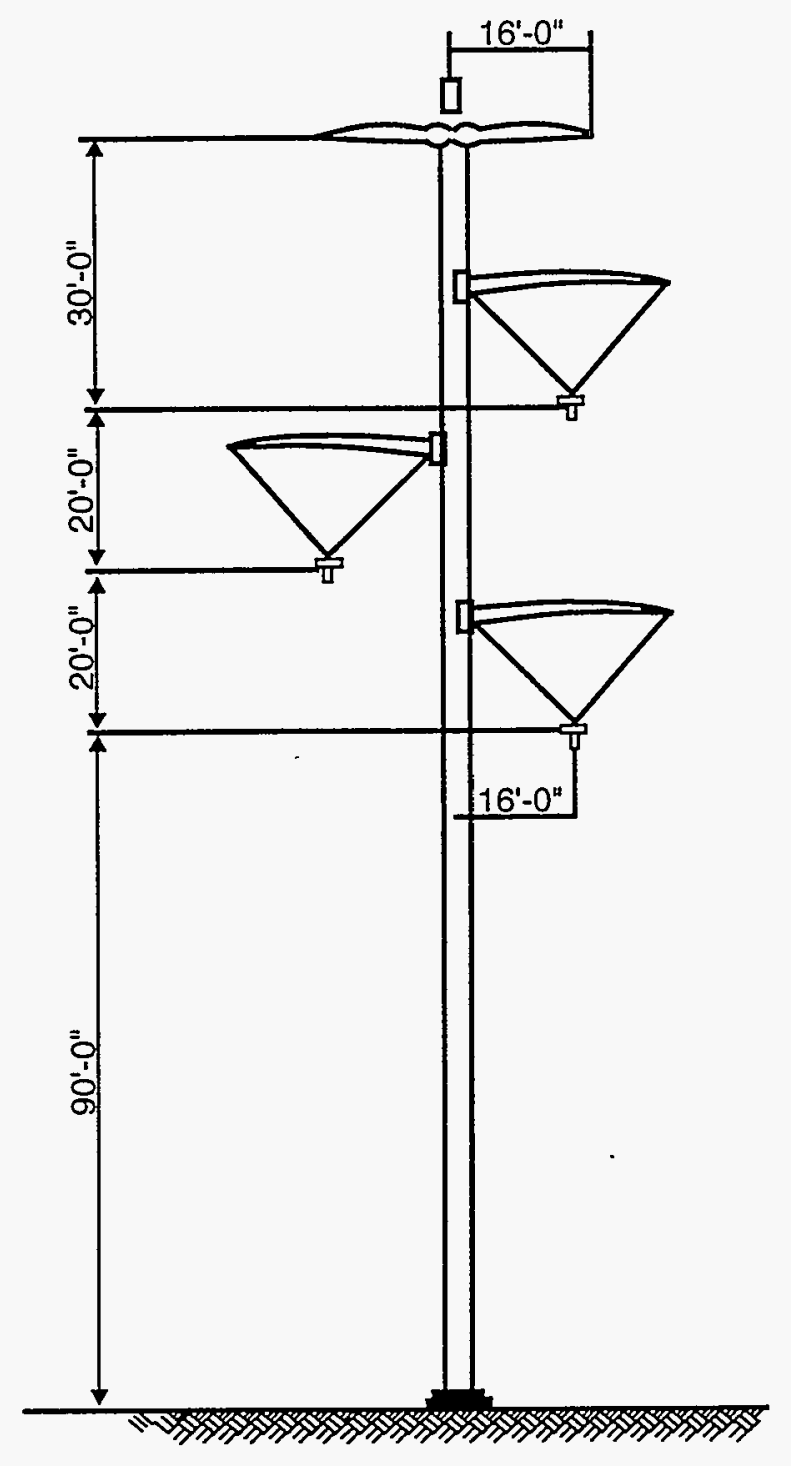

FIGURE 19 Proposed Florida 500-kV Davit Design

Table 8 also shows the EMF strengths for the davit design. The estimated construction cost (Table 9) for this design is $\$ 606,000 / \mathrm{mi}$.

Proposed 500-kV Delta Configuration. Figure 20 shows the proposed 500-kV delta configuration. The shield wires are placed $17.5 \mathrm{ft}$ above the top conductor and $16 \mathrm{ft}$ on either side of the centerline.

Table 8 also shows the EMF strengths for the delta design. The estimated construction cost (Table 9) for this design is $\$ 593,000 / \mathrm{mi}$. 
TABLE 9 Estimated Costs and Calculated EMF Strengths for 500-kV Designs from the Florida Study

\begin{tabular}{|c|c|c|c|c|c|}
\hline \multirow[b]{2}{*}{ Design } & \multirow[b]{2}{*}{$\begin{array}{l}\text { Cost per } \\
\text { Mile }^{\mathrm{a}}\end{array}$} & \multicolumn{4}{|c|}{ Field and Location Relative to Centerline } \\
\hline & & Field & $\begin{array}{l}\text { Maximum } \\
\text { Field }^{\mathrm{b}, \mathrm{c}}\end{array}$ & $100 \mathrm{ft}^{\mathrm{c}}$ & $200 \mathrm{ft}^{\mathrm{c}}$ \\
\hline Vertical & $\$ 534,000$ & $\begin{array}{l}\text { Magnetic }(\mathrm{mG}) \\
\text { Electric }(\mathrm{kV} / \mathrm{m})\end{array}$ & $\begin{array}{l}158 \\
6.76\end{array}$ & $\begin{array}{l}27.2 \\
0.22\end{array}$ & $\begin{array}{l}8.65 \\
0.13\end{array}$ \\
\hline Davit & $\$ 606,000$ & $\begin{array}{l}\text { Magnetic (mG) } \\
\text { Electric }(\mathrm{kV} / \mathrm{m})\end{array}$ & $\begin{array}{l}145 \\
6.19\end{array}$ & $\begin{array}{l}24.3 \\
0.52\end{array}$ & $\begin{array}{l}6.25 \\
0.15\end{array}$ \\
\hline Delta & $\$ 593,000$ & $\begin{array}{l}\text { Magnetic }(\mathrm{mG}) \\
\text { Electric }(\mathrm{kV} / \mathrm{m})\end{array}$ & $\begin{array}{l}185 \\
6.15\end{array}$ & $\begin{array}{l}23.8 \\
0.44\end{array}$ & $\begin{array}{l}6.61 \\
0.12\end{array}$ \\
\hline
\end{tabular}

a Source: Oppel and Stewart (1993).

b Maximum field inside of 160 -ft right-of-way.

c Data were generated with FIELDS 1.0 program.

The calculations yielded no dramatic decrease in the magnetic fields for either the delta or davit designs. When compared with the base-case vertical design, the delta design produced an increase in magnetic field strength of $18 \%$ at $40 \mathrm{ft}$ and a decrease of $24 \%$ at $200 \mathrm{ft}$ (Table 8), in return for a cost increase of $11 \%$ (Table 9). The davit design provided an increase in magnetic field strength of $19 \%$ at $40 \mathrm{ft}$ and a decrease of $28 \%$ at $200 \mathrm{ft}$ (Table 8 ) in return for a cost increase of $13 \%$ (Table 9).

\subsubsection{Rhode Island Study}

In 1992, Commonwealth Associates, Inc., published a report for the state of Rhode Island entitled Cost Effectiveness Analysis: Mitigation of Electromagnetic Fields. This report compared costs and EMF strengths of five different $345-\mathrm{kV}$ configurations. The configurations were

- Horizontal,

- Davit arm,

- Inverted delta,

- Split phase, and

- Underground.

For purposes of calculation, all $345-\mathrm{kV}$ configurations were assumed to have a minimum (sag point) phase-to-ground clearance of $30 \mathrm{ft}$ and currents of 1,000 A per phase, except for the split phase, where 500 A per phase was assumed to normalize power transmission capability. 


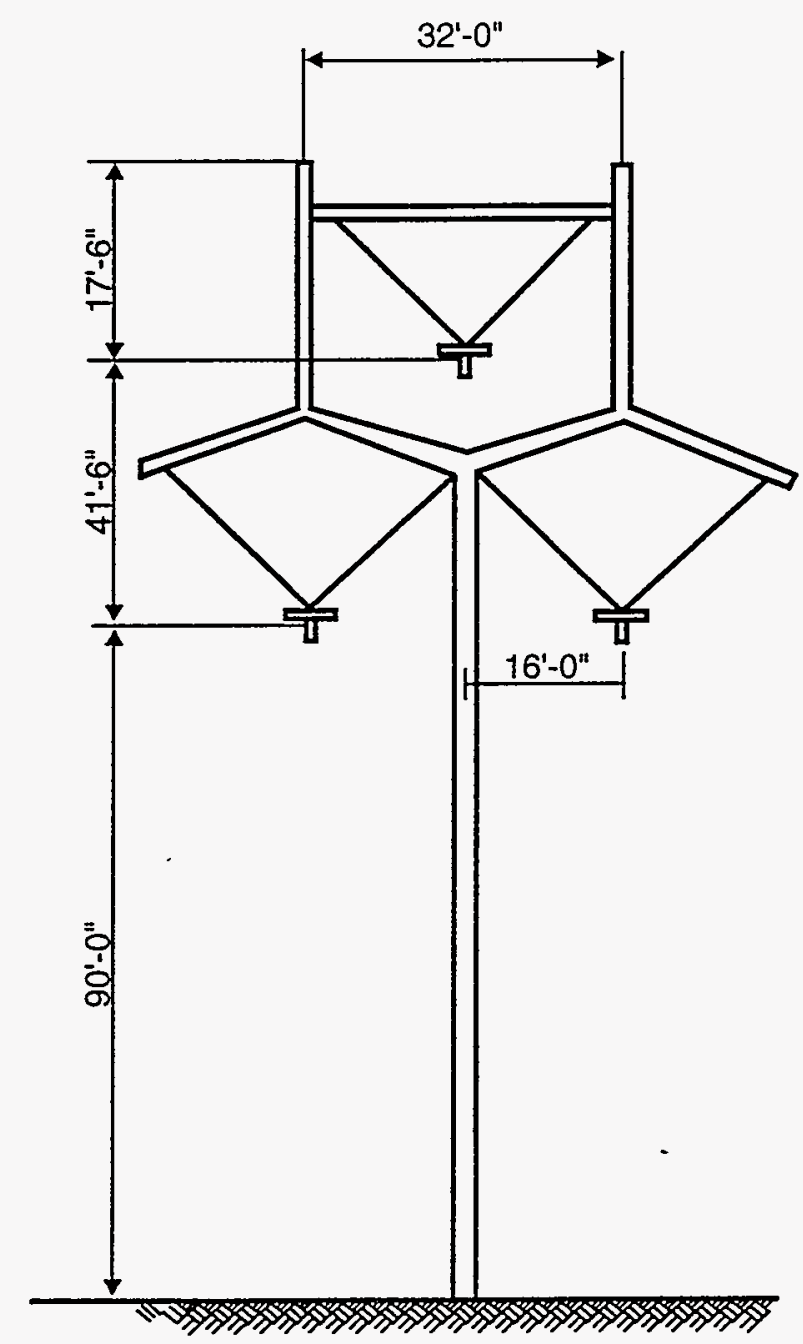

\section{FIGURE 20 Proposed Florida 500-kV Delta Design}

\subsubsection{Horizontal Configuration for 345-kV ac}

The design studied had a phase-to-phase spacing of $26 \mathrm{ft}$ and grounded shield wires $18 \mathrm{ft}$ above the top conductor and $13 \mathrm{ft}$ on either side of the transmission line centerline. New EMF strengths were calculated by using the FIELDS 1.0 computer program for various distances from the centerline and $3 \mathrm{ft}$ above ground level. The estimated construction cost in 1991 dollars for the horizontal design was $\$ 390,000 / \mathrm{mi}$.

The horizontal configuration produces the highest calculated magnetic field levels of the five designs studied (Table 10) because of the minimal height of the structure. The ineffective phase-to-phase attenuation under the conductors limits the decrease in magnetic field strength until the measuring point is moved beyond the outside conductor. Because the electric fields are less than $4.5 \mathrm{kV} / \mathrm{m}$ at all points calculated, these fields are not a great concern. 
TABLE 10 Calculated 345-kV EMF Strengths from the Rhode Island Study ${ }^{\mathrm{a}}$

\begin{tabular}{|c|c|c|c|c|c|c|c|c|}
\hline \multirow{2}{*}{$\begin{array}{c}\text { Configuration } \\
\text { and Field }\end{array}$} & \multirow{2}{*}{$\begin{array}{c}\text { Maximum } \\
\text { Field }\end{array}$} & \multicolumn{7}{|c|}{ Distance from Centerline of Structure (ft) } \\
\hline & & 0 & 20 & 40 & 60 & 80 & 100 & 200 \\
\hline \multicolumn{9}{|l|}{ Horizontal } \\
\hline $\begin{array}{l}\text { Magnetic field } \\
\text { (mG) }\end{array}$ & 210 at $0 \mathrm{ft}$ & 210 & 208 & 141 & 77.1 & 45.4 & 29.4 & 7.39 \\
\hline $\begin{array}{l}\text { Electric field } \\
(\mathrm{kV} / \mathrm{m})\end{array}$ & 4.32 at $30 \mathrm{ft}$ & 2.73 & 3.67 & 3.75 & 1.89 & 0.92 & 0.5 & 0.07 \\
\hline \multicolumn{9}{|l|}{ Davit } \\
\hline $\begin{array}{l}\text { Magnetic field } \\
\text { (mG) }\end{array}$ & $\begin{array}{l}135 \mathrm{at} \\
-10 \mathrm{ft}\end{array}$ & 132 & 95.7 & 58.7 & 35.6 & 22.8 & 15.6 & 4.23 \\
\hline $\begin{array}{l}\text { Electric field } \\
(\mathrm{kV} / \mathrm{m})\end{array}$ & $\begin{array}{l}3.64 \text { at } \\
-20 \mathrm{ft}\end{array}$ & 2.54 & 1.90 & 1.61 & 0.99 & 0.58 & 0.36 & 0.07 \\
\hline \multicolumn{9}{|l|}{ Inverted delta } \\
\hline $\begin{array}{l}\text { Magnetic field } \\
\text { (mG) }\end{array}$ & 124 at $0 \mathrm{ft}$ & 124 & 94.7 & 57.0 & 34.6 & 22.3 & 15.3 & 4.16 \\
\hline $\begin{array}{l}\text { Electric field } \\
(\mathrm{kV} / \mathrm{m})\end{array}$ & 3.95 at $0 \mathrm{ft}$ & 3.95 & 2.18 & 0.86 & 0.55 & 0.39 & 0.27 & 0.07 \\
\hline \multicolumn{9}{|l|}{ Split phase } \\
\hline $\begin{array}{l}\text { Magnetic field } \\
(\mathrm{mG})\end{array}$ & 67.4 at $0 \mathrm{ft}$ & 67.4 & 52.8 & 29.2 & 15.5 & 8.69 & 5.2 & 0.83 \\
\hline $\begin{array}{l}\text { Electric field } \\
(\mathrm{kV} / \mathrm{m})\end{array}$ & $\begin{array}{l}3.00 \mathrm{at} \\
10 \mathrm{ft}\end{array}$ & 2.45 & 2.99 & 1.36 & 0.7 & 0.46 & 0.3 & 0.05 \\
\hline \multicolumn{9}{|c|}{ Underground delta } \\
\hline $\begin{array}{l}\text { Magnetic field } \\
(\mathrm{mG})\end{array}$ & 86.2 at $0 \mathrm{ft}$ & 86.2 & 10.8 & 2.97 & 1.35 & 0.76 & 0.5 & 0.12 \\
\hline $\begin{array}{l}\text { Electric field } \\
(\mathrm{kV} / \mathrm{m})\end{array}$ & 0 & 0 & 0 & 0 & 0 & 0 & 0 & 0 \\
\hline
\end{tabular}

a Table data were generated by FIELDS 1.0 program. 


\subsubsection{Davit Arm Configuration for $345-\mathrm{kV}$ ac}

For the davit design, the phase-to-phase distance is $29 \mathrm{ft}$. All other conditions are the same as those assumed for the horizontal design, except the shield wires are $6 \mathrm{ft}$ on either side of the centerline and $20 \mathrm{ft}$ above the top conductor.

When compared with the equivalent points for the horizontal configuration, the davit design shows lower calculated EMF strengths (Table 10) at all points except one. The decreases are caused by EMF attenuation that results from the phases being closer to one another. When compared with the horizontal configuration, the davit design shows decreases in the magnetic field strength in excess of 35\% occurring at all distances from 0 to $200 \mathrm{ft}$ from the centerline. Near the centerline, the electric field strengths are much lower (40\% to 58\%) than those of the horizontal design. More than $80 \mathrm{ft}$ from the centerline, the differences in the electric field strengths decrease until the values converge at $200 \mathrm{ft}$ from the centerline.

The estimated construction cost in 1991 dollars for the davit arm configuration is $\$ 454,000 / \mathrm{mi}$. This cost is $16 \%$ higher than that of the horizontal design.

\subsubsection{Inverted-Delta Configuration for 345-kV ac}

The inverted-delta configuration has a phase-to-phase spacing of $28 \mathrm{ft}$. The shield wires are $24 \mathrm{ft}$ above the top conductors of the inverted delta and $21 \mathrm{ft}$ on either side of the centerline. At the 200 -ft point, the davit and inverted delta designs have similar EMF strengths.

The construction cost in 1991 dollars for the inverted-delta configuration is $\$ 470,000 / \mathrm{mi}$. This cost is $21 \%$ higher than that of the horizontal design.

\subsubsection{Split-Phase Configuration for $345-\mathrm{kV}$ ac}

For the split-phase design, the vertical phase-to-phase spacing was $26 \mathrm{ft}$. The horizontal (phase A to C) spacing is $24 \mathrm{ft}$ for the upper and lower arms and $48 \mathrm{ft}$ for the middle arms (phase B to B). The shield wires were $20 \mathrm{ft}$ above the top conductor and $20 \mathrm{ft}$ on either side of the centerline. To equalize the power transmission level, a current of $500 \mathrm{~A}$, instead of 1,000 A, was assumed.

The construction cost in 1991 dollars was $\$ 550,000 / \mathrm{mi}$ for the split-phase transmission line. This cost is $41 \%$ higher than that of the horizontal design.

Table 10 shows the EMF strengths for the 500-A 345-kV split-phase design. The magnetic fields are the lowest of all of the considered aboveground configurations at all measurement points. This reduction is primarily caused by the reduced conductor current levels; however, the split-phase electric fields are only slightly improved over those of the horizontal design. 


\subsubsection{Underground Delta Configuration for $345-\mathrm{kV}$ ac}

The conductors of the underground transmission system form a delta configuration. The phases are physically spaced 8 in. apart by the electrical insulation on the conductors and are buried inside a steel pipe approximately $5 \mathrm{ft}$ below the surface. By conventional utility design, the transmission pipe contains a specially formulated fluid that is kept under high pressure. This fluid helps to dissipate the power loss heat generated by the conductors.

The construction costs in 1991 dollars for this $345-\mathrm{kV}$ design type is $\$ 1,450,000 / \mathrm{mi}$. This cost, which is the highest of the five designs considered, is 3.7 times the cost of the horizontal design.

The magnetic field strengths are calculated to be very low at all points except the centerline (Table 10). This high peak followed by rapid attenuation is the result of the very close (8-in.) spacing of the conductors, which produces a peak close to the conductors but exhibits excellent phase-to-phase field cancellation effects away from the conductors. The actual fields would be significantly lower because of the attenuation effect of the steel pipe on the field. In the Rhode Island study, a $94 \%$ magnetic field reduction was calculated at the centerline when pipe shielding was taken into account. If this effect is applied to all of the magnetic field, all magnetic field strengths would be less than $1 \mathrm{mG}$. The electric field is $0 \mathrm{kV} / \mathrm{m}$ at all points because of the electric grounding effects of the earth.

\subsubsection{Washington State Study}

In 1990, the Washington State Legislature established and directed an Electric Transmission Research Needs Task Force to investigate research needs associated with limiting human exposure to EMFs from electric power transmission and distribution lines. The task force was also directed to recommend any additional research needed on ways to reduce EMF exposure.

The report (Waller and Geissinger 1992) includes a comparison of the costs and EMF fields of six $230-\mathrm{kV}$ transmission line designs. Table 11 gives the calculated values that are based on the phase spacings noted and 30 -ft minimum (sag point) ground clearances. As in the $230-\mathrm{kV}$ and $500-\mathrm{kV}$ Florida cases and the Rhode Island $345-\mathrm{kV}$ cases, the EMF impact point was $3 \mathrm{ft}$ above ground level; and the currents were 1,000 A per phase, except for the split-phase configurations, which were $500 \mathrm{~A}$ per phase to equalize power transmission. The six different configurations that were studied were

- Horizontal,

- Davit arm,

- Delta,

- Split phase,

- Vertical, and

- Underground delta. 


\section{TABLE 11 Calculated 230-kV EMF Strengths} from the Washington State Study ${ }^{a}$

\begin{tabular}{|c|c|c|c|c|c|c|c|c|}
\hline \multirow{2}{*}{$\begin{array}{l}\text { Configuration } \\
\text { and Field }\end{array}$} & \multirow{2}{*}{$\begin{array}{l}\text { Maximum } \\
\text { Field }\end{array}$} & \multicolumn{7}{|c|}{ Distance from Centerline of Structure (ft) } \\
\hline & & 0 & 20 & 40 & 60 & 80 & 100 & 200 \\
\hline \multicolumn{9}{|l|}{ Horizontal } \\
\hline $\begin{array}{l}\text { Magnetic field } \\
(\mathrm{mG})\end{array}$ & 198 at $0 \mathrm{ft}$ & 198 & 172 & 99 & 53.3 & 31.8 & 21 & 5.36 \\
\hline $\begin{array}{l}\text { Electric field } \\
(\mathrm{kV} / \mathrm{m})\end{array}$ & 2.35 at $20 \mathrm{ft}$ & 1.21 & 2.35 & 1.76 & 0.82 & 0.4 & 0.2 & 0.03 \\
\hline \multicolumn{9}{|l|}{ Davit arm } \\
\hline $\begin{array}{l}\text { Magnetic field } \\
(\mathrm{mG})\end{array}$ & 90.5 at $0 \mathrm{ft}$ & 90.5 & 69.5 & 37.1 & 20.4 & 12.4 & 8.2 & 2.13 \\
\hline $\begin{array}{l}\text { Electric field } \\
(\mathrm{kV} / \mathrm{m})\end{array}$ & 1.80 at $10 \mathrm{ft}$ & 1.52 & 1.51 & 0.67 & 0.33 & 0.2 & 0.1 & 0.03 \\
\hline \multicolumn{9}{|l|}{ Delta } \\
\hline $\begin{array}{l}\text { Magnetic field } \\
\text { (mG) }\end{array}$ & 93.5 at $0 \mathrm{ft}$ & 93.5 & 64.5 & 32.5 & 17.6 & 10.7 & 7.1 & 1.82 \\
\hline $\begin{array}{l}\text { Electric field } \\
(\mathrm{kV} / \mathrm{m})\end{array}$ & 1.60 at $10 \mathrm{ft}$ & 1.47 & 1.43 & 0.67 & 0.3 & 0.16 & 0.1 & 0.02 \\
\hline \multicolumn{9}{|l|}{ Split phase } \\
\hline $\begin{array}{l}\text { Magnetic field } \\
(\mathrm{mG})\end{array}$ & 48.2 at $0 \mathrm{ft}$ & 48.2 & 33.9 & 16.1 & 7.7 & 4.06 & 2.3 & 0.35 \\
\hline $\begin{array}{l}\text { Electric field } \\
(\mathrm{kV} / \mathrm{m})\end{array}$ & 1.40 at $10 \mathrm{ft}$ & 1.13 & 1.4 & 0.51 & 0.11 & 0.03 & 0 & 0.01 \\
\hline \multicolumn{9}{|l|}{ Vertical } \\
\hline $\begin{array}{l}\text { Magnetic field } \\
(\mathrm{mG})\end{array}$ & 109 at $0 \mathrm{ft}$ & 109 & 81.9 & 48.7 & 29.8 & 19.4 & 14 & 3.8 \\
\hline $\begin{array}{l}\text { Electric field } \\
(\mathrm{kV} / \mathrm{m})\end{array}$ & 2.38 at $0 \mathrm{ft}$ & 2.38 & 1.26 & 0.29 & 0.03 & 0.08 & 0.1 & 0.04 \\
\hline \multicolumn{9}{|c|}{ Underground delta } \\
\hline $\begin{array}{l}\text { Magnetic field } \\
(\mathrm{mG})\end{array}$ & 86.2 at $0 \mathrm{ft}$ & 86.2 & 10.8 & 2.97 & 1.35 & 0.76 & 0.5 & 0.12 \\
\hline $\begin{array}{l}\text { Electric field } \\
(\mathrm{kV} / \mathrm{m})\end{array}$ & 0 & 0 & 0 & 0 & 0 & 0 & 0 & 0 \\
\hline
\end{tabular}

a Table data were generated by FIELDS 1.0 program. 


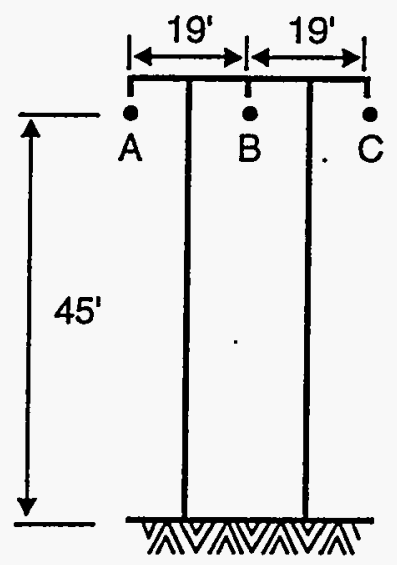

FIGURE 21 Horizontal Configuration for $230-\mathrm{kV}$ ac

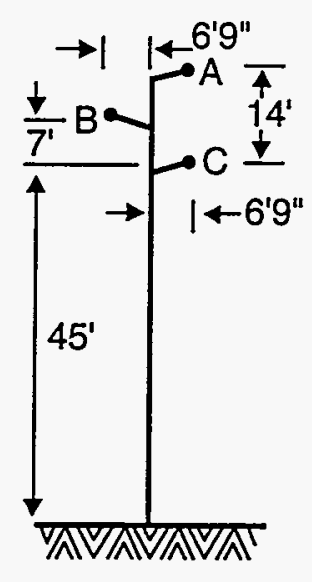

FIGURE 22

Davit Arm

Configuration

for $230-\mathrm{kV}$ ac

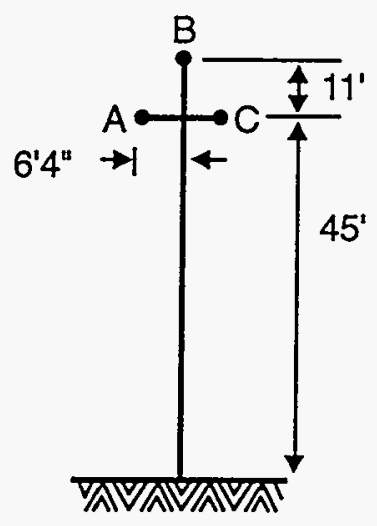

FIGURE 23 Delta Configuration for 230-kV ac

\subsubsection{Horizontal Configuration for $230-\mathrm{kV}$ ac}

This design had a phase-to-phase spacing of $19 \mathrm{ft}$ and grounded shield wires $15 \mathrm{ft}$ above the conductor and $15 \mathrm{ft}$ on either side of the tower's centerline (Figure 21). The estimated construction cost in 1991 dollars was $\$ 230,000-\$ 260,000 / \mathrm{mi}$ for the horizontal design.

This configuration produced the highest calculated magnetic field levels (Table 11) of these $230-\mathrm{kV}$ configurations. The electric field strengths are not a great concern because they are less than $2.5 \mathrm{kV} / \mathrm{m}$ at any location beneath or near the lines.

\subsubsection{Davit Arm Configuration for $230-\mathrm{kV}$ ac}

For the $230-\mathrm{kV}$ davit arm design, the phase-to-phase distance was $14 \mathrm{ft}$ (Figure 22). The shield wire was assumed to be placed at the centerline and $20 \mathrm{ft}$ above the topmost conductor.

Table 11 also lists the EMF strengths at all points for the davit arm design. Because the electric field strengths are $1.80 \mathrm{kV} / \mathrm{m}$ or less, the electric fields are low enough to be of little concern.

The estimated construction cost in 1991 dollars was $\$ 230,000-\$ 250,000 / \mathrm{mi}$ for the davit arm design. This cost is about the same as that for the horizontal design.

\subsubsection{Delta Configuration for $230-\mathrm{kV}$ ac}

The phase-to-phase spacing for the delta design (Figure 23) was $12.7 \mathrm{ft}$. Two shield wires are placed $19 \mathrm{ft}$ above the top conductor and $6 \mathrm{ft}$ on either side of the centerline. 
Table 11 shows that the magnetic field at the centerline for the delta design is slightly higher than that of the davit arm but still much improved over that of the horizontal design. At the 200-ft point, the magnetic field of the delta design is $14 \%$ lower than that of the davit arm design and 66\% lower than that of the horizontal design.

The construction cost in 1991 dollars for this configuration is $\$ 220,000-\$ 250,000 / \mathrm{mi}$. As with the davit arm, this cost is about the same as that of the horizontal design.

\subsubsection{Split-Phase Configuration for $230-\mathrm{kV}$ ac}

Figure 24 presents a typical $230-\mathrm{kV}$ split-phase design. The horizontal spacing from phase $A$ to phase $C$ is $18 \mathrm{ft} 8$ in. and from phase $B$ to phase $C$ and from phase $B$ to phase $A$ is about $14 \mathrm{ft}$. The design shows a vertical spacing from phase $B$ to phase $A$ and from phase $B$ to phase $\mathrm{C}$ of $14 \mathrm{ft}$. Two grounded shield wires are $20 \mathrm{ft}$ above the top conductors and $6 \mathrm{ft}$ on either side of the centerline. Currents of $500 \mathrm{~A}$ per phase were assumed.

Table 11 shows the results of the EMF calculations. The magnetic fields for the split-phase design are the lowest of all of the considered aboveground configurations at all measurement points, primarily because of the lower currents.

The estimated construction cost in 1991 dollars was $\$ 350,000-\$ 400,000 / \mathrm{mi}$ for the split-phase transmission line. This cost is $54 \%$ higher than that for the base-case horizontal design.

\subsubsection{Vertical Configuration for $230-\mathrm{kV}$ ac}

This vertical configuration (Figure 25) had a 14-ft phase-to-phase spacing and a single shield wire $12 \mathrm{ft}$ above the top conductor at the centerline. The calculated magnetic field strengths for the vertical design are $20 \%$ higher than those of the davit arm design but $45 \%$ lower than those of the base-case horizontal design. The electric field strengths are below $2.5 \mathrm{kV} / \mathrm{m}$ at all points.

The estimated construction cost in 1991 dollars was $\$ 275,000-\$ 350,000 / \mathrm{mi}$ for this design. This cost is an increase of $35 \%$ over that of the horizontal design.

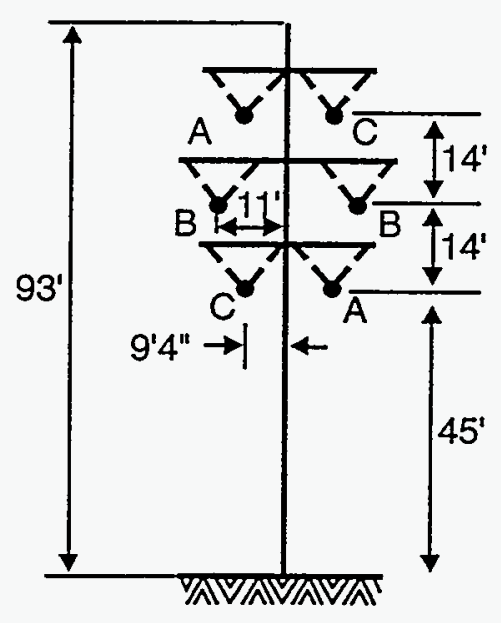

FIGURE 24 Split-Phase Configuration for 230-kV ac

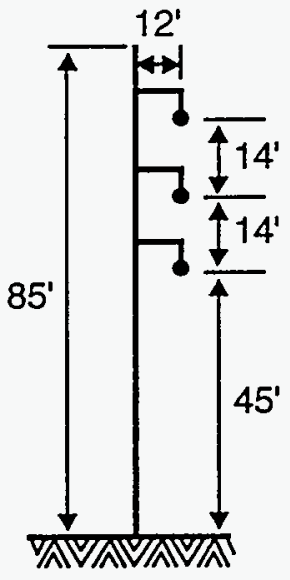

FIGURE 25 Vertical Configuration for 230-kV ac 


\subsubsection{Underground Configuration for $230-\mathrm{kV}$ ac}

The underground transmission system naturally assumes a delta conductor configuration (Figure 26). The phases are physically spaced $8 \mathrm{in}$. apart by the electrical insulation on the conductors and are buried inside a steel pipe approximately $5 \mathrm{ft}$ below ground. The transmission pipe contains a specially formulated fluid at high pressure to dissipate the power loss heat of the conductors.

This design option has the highest estimated construction cost of all of the $230-\mathrm{kV}$ configurations considered. The construction cost in 1991 dollars for the underground design was estimated at $\$ 1,500,000-\$ 2,000,000 / \mathrm{mi}$. This cost is an $870 \%$ increase over that of the horizontal design.

Calculated magnetic field strengths for the underground delta design are very low at all points except along the centerline. This reduction is a consequence of the very close (i.e., 8-in.) spacing of the conductors. The actual magnetic fields will be significantly lower because of the attenuation effect of the steel pipe on the field. The Rhode Island study (Commonwealth Associates, Inc. 1992) estimates a 94\% reduction of the calculated results because of the shielding effects of the pipe. If this factor is applied to the Washington state study values in Table 11, the centerline field would be less than $6 \mathrm{mG}$, and all points beyond $20 \mathrm{ft}$ would have magnetic field strengths of less than $1 \mathrm{mG}$. No electric fields exist around the pipe because of the electrical grounding of the earth.

\subsubsection{Bonneville Power Administration 500-kV Estimation Study}

A 1992 Bonneville Power Administration (BPA) memorandum (A.M. Wykoff, unpublished information) provided information concerning transmission-line construction-cost estimating data for $500-\mathrm{kV}$ delta and split-phase transmission lines that use different sizes of conductors. The data included a breakdown of the material and construction costs per mile of transmission lines. These data were to be used for initial planning purposes. The data included estimated costs for different conductors. The conductor costs that were provided are as follows:

- Delta configuration with 3,578-MCM conductors, $\$ 354,000 / \mathrm{mi}$;

- Delta configuration with 5,607-MCM conductors, $\$ 410,000 / \mathrm{mi}$;

- Split-phase configuration with 3,578-MCM conductors, $\$ 790,000 / \mathrm{mi}$;

- Split-phase configuration with 5,607-MCM conductors, $\$ 881,000 / \mathrm{mi}$; and

- Split-phase configuration with 6,935-MCM conductors, $\$ 950,000 / \mathrm{mi}$.

The MCM is the unit used to denote the size of conductors and stands for 1,000 circular mils (kilo circular mil). The MCM unit is derived by squaring the diameter of 


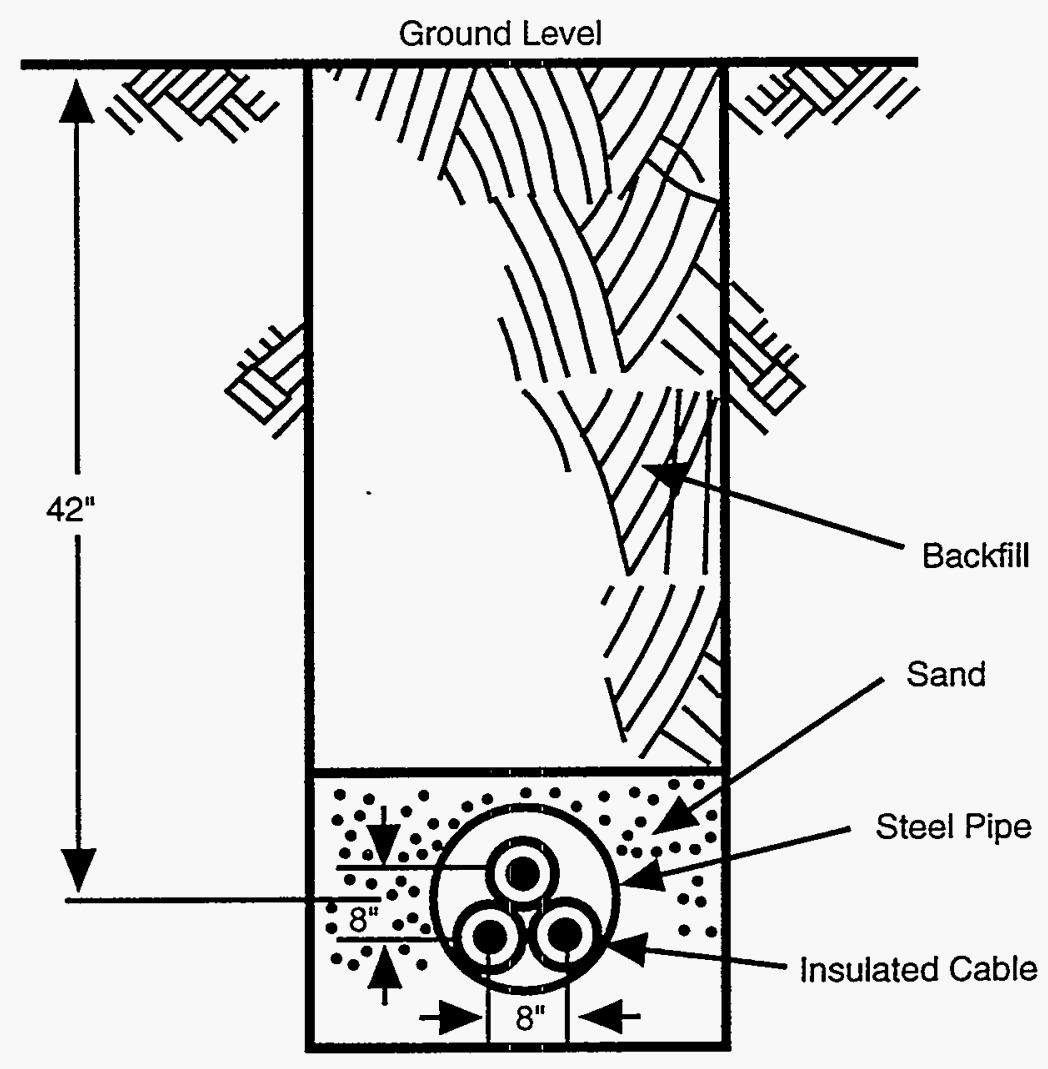

FIGURE 26 Underground Configuration for $230-\mathrm{kV}$ ac

the conductor in mils (thousandths of an inch) and then dividing by 1,000 . Hence, to determine the diameter of a 5,607-MCM conductor, one would multiply 5,607 (MCMs) by 1,000 to determine its circular measurement in mils. Taking the square root of this measurement $(5,607,000)$ would yield 2,367 , which is the diameter of the conductor in mils. Thus, a 5,607-MCM conductor would have a diameter of 2.367 in.

High-voltage transmission lines are generally uninsulated aluminum-core steelreinforced (ACSR) cables. For ease of production and reduced corona effects, a single large high-voltage conductor is not used. Instead, the conductors actually consist of numerous smaller ACSR conductors; for instance, a 5,607-MCM cable is actually composed of three 1,867-MCM ACSR conductors, each of which has a diameter of 1.366 in.

As can be seen from the previous data, reducing the size of the cable can significantly reduce the cost of constructing an electric power transmission line. Extrapolation of a linear model that is based on the costs of the three split-phase configurations noted previously to a conductor size of $2,804 \mathrm{MCM}$ yields a cost of $\$ 657,000 / \mathrm{mi}$. As pointed out by Oppel and Stewart (1993), the split-phase design also offers minimum line impedance, which, in turn, allows improved surge impedance for maximum power transfer capability. 
TABLE 12 Comparative Construction Costs and EMF Strengths for Two 500-kV Low-EMF Transmission Line Designs

\begin{tabular}{|c|c|c|c|c|c|}
\hline \multirow[b]{2}{*}{ Design } & \multirow{2}{*}{$\begin{array}{c}\text { Cost } \\
\text { per Mile }\end{array}$} & \multicolumn{4}{|c|}{ Field and Location Relative to Centerline } \\
\hline & & Field & Maximum Field ${ }^{\mathrm{a}}$ & $120 \mathrm{ft}$ & $200 \mathrm{ft}$ \\
\hline \multirow[t]{2}{*}{ Delta } & $\begin{array}{l}\$ 410,000^{\mathrm{b}} \\
(5,607 \mathrm{MCM})\end{array}$ & Magnetic (mG) & 181 at $0 \mathrm{ft}$ & 13.3 & 4.86 \\
\hline & & Electric $(\mathrm{kV} / \mathrm{m})$ & 5.80 at $20 \mathrm{ft}$ & 0.27 & 0.09 \\
\hline \multirow[t]{2}{*}{ Split phase } & $\$ 657,000^{\mathrm{c}}$ & Magnetic (mG) & 158 at $0 \mathrm{ft}$ & 8.60 & 2.28 \\
\hline & & Electric $(\mathrm{kV} / \mathrm{m})$ & 5.12 at $20 \mathrm{ft}$ & 0.27 & 0.08 \\
\hline
\end{tabular}

a Maximum field inside a 160-ft right-of-way at $3 \mathrm{ft}$ above ground level.

b Șource: Lee et al. (1993).

c Extrapolation of data from Lee et al. (1993).

The EMF strengths for the 500-kV delta and split-phase configurations calculated in Section 3.3.1.2 of this report, the construction costs for the 5,607-MCM 500-kV delta configuration provided by the BPA, and extrapolation of the BPA-provided construction costs for $500-\mathrm{kV}$ split-phase configurations to a 2,804-MCM size were combined to produce Table 12. Although both the delta and split-phase configurations produce low EMF strengths, the magnetic field of the split-phase configuration is $12.7 \%$ lower than that of the delta configuration at the centerline and is $53 \%$ lower at $200 \mathrm{ft}$ from the centerline; however, these reduced magnetic fields would require a $60 \%$ increase in the per-mile construction costs. 


\section{CONCLUSIONS}

\subsection{SENSITIVITY STUDY}

Calculations were made to quantify the change in magnetic or electric field strengths near high-voltage electric transmission lines when the conductors are either moved closer together or the line height is increased. Coefficients (called the compacting sensitivity or the height sensitivity) were developed to report the calculated changes in EMF strengths per foot of conductor movement for several different designs for transmission lines and at several different voltages. The values for sensitivity are the percent per foot that the magnetic or electric field decreases (positive value) when the phase-to-phase distance is compacted (decreased) by $5 \mathrm{ft}$ or the phase-to-ground height is increased by $5 \mathrm{ft}$.

The results in Table 13 are representative of the values for the compacting and height sensitivity at 100 and $200 \mathrm{ft}$ from the transmission line's centerline that were calculated for four $345-\mathrm{kV}$ power line configurations (horizontal, delta, davit, and split phase). Table 13 shows that the phase-to-phase magnetic field compacting sensitivity ranges from less than $4 \% / \mathrm{ft}$ to more than $5 \% / \mathrm{ft}$ if the conductors are assumed to be $5 \mathrm{ft}$ closer to each other. One conclusion that can be drawn from Table 13 is that all of the configurations will yield similar field reductions when the phases are compacted.

The compacting strategy might be useful when a localized area (such as a school or residential area) requires a low magnetic field. The phases could be compacted for a limited portion of the line to meet the local need and should not affect the overall performance of the line in a substantial way. The compacted portion would incur additional corona losses and have increased phase-to-phase capacitance; however, calculations or tests should be made to ensure that the compaction has no significant impact on the reliability of the transmission line (that the compacted phase-to-phase distance offers reasonably low probabilities of arcover between lines)

Small increases of the phase-to-ground height of a power line are much less effective for reducing magnetic field strength than compacting the phase-to-phase distances. Large

TABLE 13 Sensitivity Analysis for Four 345-kV Configurations

\begin{tabular}{lcccccc}
\hline & \multicolumn{2}{c}{$\begin{array}{c}\text { Compacting Sensitivity } \\
(\% / \mathrm{ft})\end{array}$} & & \multicolumn{2}{c}{$\begin{array}{c}\text { Height Sensitivity } \\
(\% / \mathrm{ft})\end{array}$} \\
\cline { 2 - 3 } $\begin{array}{c}\text { 345-kV } \\
\text { Configuration }\end{array}$ & At $100 \mathrm{ft}^{\mathrm{a}}$ & At $200 \mathrm{ft}^{\mathrm{a}}$ & & At $100 \mathrm{ft}^{\mathrm{a}}$ & At $200 \mathrm{ft}^{\mathrm{a}}$ \\
\hline Horizontal & 4.71 & 4.49 & & 0.62 & 0.15 \\
Delta & 4.03 & 3.88 & & 0.63 & 0.16 \\
Davit & 4.61 & 4.57 & & 0.77 & 0.21 \\
Split phase & 5.58 & 5.17 & & 1.05 & 0.30 \\
\hline
\end{tabular}

a Distance from centerline. 
increases in the height of a transmission line would necessitate stronger towers because of wind loading. Stronger towers, in turn, increase the construction costs. These latter considerations, plus the relatively small reduction in magnetic field strengths, discourage the use of small increases in the height of the tower as a means of reducing magnetic fields, except where the requirements for such reduction are severe and where no compaction or configurational changes are possible.

\subsection{STUDY OF COST VERSUS FIELDS}

Table 14 presents the overall comparisons of construction cost versus EMF strengths for the $345-\mathrm{kV}$ ac designs from the Rhode Island study (Commonwealth Associates, Inc. 1992). Table 14 clearly shows the trade-off between cost and reduction in magnetic field strength, where the least costly (to construct) horizontal configuration has the highest magnetic fields. By changing configurations, the $16 \%, 21 \%$, and $41 \%$ increases in the construction costs for overhead davit, inverted-delta, or split-phase lines obtain, respectively, magnetic field reductions of $36 \%, 41 \%$, and $68 \%$ at the maximum field points and reductions of $43 \%, 44 \%$, and $89 \%$ at $200 \mathrm{ft}$ from the centerline. Changing an overhead horizontal system to an underground system yielded even more impressive results, but at an equally impressive increase in construction costs. In this case, a 3.7-fold (370\%) increase in construction costs provided a calculated $59 \%$ and $98 \%$ reduction in magnetic fields at the maximum field point

TABLE 14 Estimated Costs and Calculated EMF Strengths for Five 345-kV Power Line Configurations from the Rhode Island Study

\begin{tabular}{|c|c|c|c|c|}
\hline \multirow[b]{2}{*}{ Design } & \multirow[b]{2}{*}{$\begin{array}{c}\text { Cost } \\
\text { per Mile }\end{array}$} & \multicolumn{3}{|c|}{ EMF Strengths and Location Relative to Centerline } \\
\hline & & Field & $\begin{array}{l}\text { Maximum Field } \\
\text { and Location }\end{array}$ & $\begin{array}{l}\text { Field } \\
\text { at } 200 \mathrm{ft}\end{array}$ \\
\hline Horizontal & $\$ 390,000$ & $\begin{array}{l}\text { Magnetic }(\mathrm{mG}) \\
\text { Electric }(\mathrm{kV} / \mathrm{m})\end{array}$ & $\begin{array}{l}210 \text { at } 0 \mathrm{ft} \\
4.32 \text { at } 30 \mathrm{ft}\end{array}$ & $\begin{array}{l}7.39 \\
0.07\end{array}$ \\
\hline Davit & $\$ 454,000$ & $\begin{array}{l}\text { Magnetic }(\mathrm{mG}) \\
\text { Electric }(\mathrm{kV} / \mathrm{m})\end{array}$ & $\begin{array}{l}135 \text { at } 10 \mathrm{ft} \\
3.64 \text { at } 20 \mathrm{ft}\end{array}$ & $\begin{array}{l}4.23 \\
0.07\end{array}$ \\
\hline $\begin{array}{l}\text { Inverted } \\
\text { delta }\end{array}$ & $\$ 470,000$ & $\begin{array}{l}\text { Magnetic (mG) } \\
\text { Electric }(\mathrm{kV} / \mathrm{m})\end{array}$ & $\begin{array}{l}124 \text { at } 0 \mathrm{ft} \\
3.95 \text { at } 0 \mathrm{ft}\end{array}$ & $\begin{array}{l}4.16 \\
0.07\end{array}$ \\
\hline $\begin{array}{l}\text { Split phase } \\
(I=500 \mathrm{~A})\end{array}$ & $\$ 550,000$ & $\begin{array}{l}\text { Magnetic }(\mathrm{mG}) \\
\text { Electric }(\mathrm{kV} / \mathrm{m})\end{array}$ & $\begin{array}{l}67.4 \text { at } 0 \mathrm{ft} \\
3.00 \text { at } 10 \mathrm{ft}\end{array}$ & $\begin{array}{l}0.83 \\
0.05\end{array}$ \\
\hline Underground & $\$ 1,450,000$ & Magnetic (mG) & $\begin{array}{c}86.2 \text { at } 0 \mathrm{ft} \\
\text { (unshielded); } \\
5.2 \text { at } 0 \mathrm{ft} \\
\text { (pipe shield) }\end{array}$ & 0.12 \\
\hline & & Electric $(\mathrm{kV} / \mathrm{m})$ & 0 & 0 \\
\hline
\end{tabular}

a Source: Commonwealth Associates, Inc. (1992). 
for the unshielded and pipe-shielded conditions, respectively. At $500 \mathrm{kV}$, a similar trade-off of an increase in construction cost for magnetic field reduction is noted when the calculations of magnetic field strength and the data on construction costs for several overhead power line configurations are reviewed.

Previous studies and the calculations made for this report show that small changes in magnetic fields are obtainable at reasonable cost by compacting the phase-to-phase spacing of power lines but at a possible decrease in the reliability of the power line. Even smaller reductions in the magnetic field can be obtained by increasing the phase-to-ground height of power lines, but the costs to do so may be prohibitively high for the small amount of magnetic field reduction that can be achieved; however, significant reductions in magnetic field strength can be obtained by changing the power line configuration to a configuration that is more costly to construct. The most expensive (to construct) power line design, the underground system, is also the design that produced the lowest magnetic fields; however, the very high cost of the underground system would restrict its application for magnetic field reduction to only those locations where severe restrictions on magnetic fields apply. 


\section{REFERENCES}

Bracken, T.D., et al., 1978, "Ground Level Electric Fields and Ion Currents on the CeliloSylmar $\pm 400-\mathrm{kV}$ D.C. Intertie during Fair Weather," IEEE Transactions on Power Apparatus and Systems PAS 97:370-378.

Commonwealth Associates, Inc., 1992, Cost Effectiveness Analysis: Mitigation of Electromagnetic Fields, Jackson, Mich., May.

Fink, D.G., and J.M. Carroll (editors), 1969, Standard Handbook for Electrical Engineers, 10th ed., McGraw-Hill Book Co., New York, N.Y.

General Electric Co., 1982, Transmission Line Reference Book: $345 \mathrm{kV}$ and Above, 2nd ed., Electric Power Research Institute, Palo Alto, Calif.

IEEE: See Institute of Electrical and Electronics Engineers, Inc.

Institute of Electrical and Electronics Engineers, Inc., 1990, National Electrical Safety Code, New York, N.Y., Feb.

Lee, J.M., Jr., et al., 1993, Electrical and Biological Effects of Transmission Lines: A Review (revised), Bonneville Power Administration, Portland, Ore., Feb.

Moore, T., 1990, "Looking Ahead on EMF," EPRI Journal 15(6):5-19, Oct./Nov.

Oppel, L.J., and J.R. Stewart, 1993, Attenuation of Electromagnetic Fields from Electrical Transmission Lines, PTI 25-93, Power Technologies, Inc., Schenectady, N.Y.

Waller, P., and L. Geissinger, 1992, Electric and Magnetic Field Reduction: Research Needs, Washington State Transmission Research Needs Task Force, Olympia, Wash., Jan. 


\section{BIBLIOGRAPHY}

Burns, C.W., et al., 1991, "Series-Capacitor Compensated Shield Scheme for Enhanced Mitigation," in Proceedings of the 1991 IEEE Power Engineering Society Transmission and Distribution Conference, Dallas, Tex., Institute of Electrical and Electronics Engineers, Inc., New York, N.Y.

Electric Power Research Institute, 1989, Electric and Magnetic Fields: Human Health Studies, EN 301011 89, Palo Alto, Calif., Nov.

Johnson, T.R., et al., 1993, Magnetic Field Reduction Research, Empire State Electric Energy Research Corp., New York, N.Y., July.

Microwave News, 1992, "The Economics of Mitigation," 12(4)4, July-Aug.

Moore, T., 1992, "The Pace Quickens in EMF Research," EPRI Journal 17(2):5-13, March.

Moore, T., 1993, "Exploring the Options for Magnetic Field Management," EPRI Journal 18(6):5-13, Oct./Nov.

Rodick, S., and P. Musser, 1993, "Evaluation of Measures and Costs to Mitigate Magnetic Fields from Transmission and Distribution Lines," presented at the Missouri Valley Electric Association Engineering Conference, Kansas City, Mo., April 7.

Ross, D.F., 1991, "Balancing the Interests of Customers, Shareholders and the Public," The Electricity Journal 4(3):46-53, April.

Stewart, J.R., et al., 1993, "Magnetic Field Reduction Using High Phase Order Lines," IEEE Power Engineering Society Transmission and Distribution Committee, IEEE Transactions on Power Delivery, vol. 8, No. 2, April.

U.S. Environmental Protection Agency, 1992, Electric and Magnetic Fields: An EPA Perspective on Research Needs and Priorities for Improving Health Risk Assessment, EPA/600/9-91/016F, Washington, D.C., Dec.

Watson, T., and M. Warnquist, 1991, "EMF: Liability, Prudent Avoidance, and Communication," The Electricity Journal 4(3):40-45, April. 


\section{APPENDIX A:}

\section{SENSITIVITY CALCULATIONS}

This appendix contains the calculated EMF strengths of electric power transmission lines for various spacing configurations at $765-\mathrm{kV}, 500-\mathrm{kV}$, and $345-\mathrm{kV}$ ac and for one configuration at $\pm 450-\mathrm{kV}$ dc as a function of distance from the centerline of the power line. The calculations were made by using the FIELDS 1.0 personal-computer program from Southern California Edison Co. This program uses the basic algorithms from the EPRI Transmission Line Reference Book (General Electric Co. 1982). The electric field calculation assumes that the earth is a perfect conductor and sums the vector components of the electric fields created by the charge on each conductor of each phase. Likewise, the magnetic field calculation sums the vector components of the magnetic fields from an assumed current in each of the conductors of each phase.

All calculations were repeated for a compact design where the phases are $5 \mathrm{ft}$ closer to each other than in the original calculation. The comparative EMF strengths were then used to calculate the compacting sensitivity (in percent per foot) caused by compacting the phase-to-phase clearance. The calculation was repeated a third time with the original phase-to-phase clearance but with the phase-to-ground distance increased by $5 \mathrm{ft}$. This change produced new values of EMF strengths that were used to calculate height sensitivity caused by changes in the height of the conductor above ground.

As an example of how to use the sensitivity values, suppose that the magnetic field strength for a particular power-line configuration at a particular voltage is $15 \mathrm{mG}$ at $200 \mathrm{ft}$ from the centerline of the power line. Also assume that the applicable compacting sensitivity is $2.5 \% / \mathrm{ft}$ and the applicable height sensitivity is $0.5 \% / \mathrm{ft}$. If one wants to consider the options available to manipulate line spacing or increase line height to reduce the field to $12.5 \mathrm{mG}$, a calculation can be made to determine how much to reduce the phase-to-phase (or phase-toground) spacing to achieve the 12.5-mG objective.

For example, to calculate the desired percentage of field reduction, $12.5 \mathrm{mG} / 15 \mathrm{mG}=0.8333$. This percentage requires a $17 \%$ field reduction; then $17 \% /(2.5 \% / \mathrm{ft})$ $=6.8 \mathrm{ft}$ of phase-to-phase distance reduction will result in a $12.5-\mathrm{mG}$ field at $200 \mathrm{ft}$.

The tables in this appendix contain the results of the FIELDS 1.0 personal-computer program's calculations of EMF strengths for one $765-\mathrm{kV}$ ac transmission-line configuration, five $500-\mathrm{kV}$ ac configurations, four $365-\mathrm{kV}$ ac configurations, and one $\pm 450-\mathrm{kV} \mathrm{dc}$ configuration. The tables also include the data on EMF strengths for each of these configurations at several distances from 0 to $200 \mathrm{ft}$ under both the compacted-phase condition and the raised-height condition. Finally, the tables include the results of calculations of both the compacting sensitivity and the height sensitivity for each of the configurations and at several distances from 0 to $200 \mathrm{ft}$ from the transmission line centerline. 


\section{A.1 HORIZONTAL CONFIGURATION FOR 765-kV ac}

For the 765-kV ac horizontal configuration (Figure 3), the following conditions and spacing were assumed for each of the calculations for baseline or nominal conditions; the coordinates of the three phases are specified in relation to the tower's centerline $(x=0 \mathrm{ft})$ and to ground level $(y=0 \mathrm{ft})$ :

- Coordinates of phase conductors,

- Phase A, $x=-40 \mathrm{ft}$ and $y=45 \mathrm{ft}$ (at sag point for the line considered),

- Phase B, $x=0 \mathrm{ft}$ and $y=45 \mathrm{ft}$,

- Phase C, $x=40 \mathrm{ft}$ and $y=45 \mathrm{ft}$;

- Phase current of $1,000 \mathrm{~A}$;

- Minimum phase-to-ground distance (per NESC [IEEE 1990]) of $30 \mathrm{ft}$ (at conductor sag point);

- Coordinates of grounded shield wires at tower,

- Wire $1, x=-30 \mathrm{ft}$ and $y=65 \mathrm{ft}$,

- Wire $2, x=30 \mathrm{ft}$ and $y=65 \mathrm{ft}$; and

- Height of points of calculated EMFs (Table A.1) equals $3 \mathrm{ft}$ above ground level.

\section{A.2 CONFIGURATIONS FOR 500-kV ac}

\section{A.2.1 Horizontal Configuration for $500-\mathrm{kV}$ ac}

For the $500-\mathrm{kV}$ ac horizontal configuration (Figure 4), the following conditions and spacing were assumed for each of the calculations for baseline or nominal conditions; the coordinates of the three phases are specified in relation to the tower's centerline $(x=0 \mathrm{ft})$ and to ground level $(y=0 \mathrm{ft})$ :

- Coordinates of phase conductors,

- Phase A, $x=-35 \mathrm{ft}$ and $y=30 \mathrm{ft}$ (at sag point for the line considered),

- Phase B, $x=0 \mathrm{ft}$ and $y=30 \mathrm{ft}$,

- Phase C, $x=35 \mathrm{ft}$ and $y=30 \mathrm{ft}$;

- Phase current of $1,000 \mathrm{~A}$;

- Minimum phase-to-ground distance (per NESC [IEEE 1990]) of $30 \mathrm{ft}$ (at conductor sag point); 
TABLE A.1 Calculated EMF Strengths and Sensitivities for $765-\mathrm{kV}$ ac Horizontal Configuration at 1,000 A per Phase

\begin{tabular}{cccccc}
\hline & \multicolumn{3}{c}{ Field Strength $^{\mathrm{b}}$} & & \\
\cline { 2 - 4 } $\begin{array}{c}\text { Distance from } \\
\text { Centerline (ft) }\end{array}$ & $\begin{array}{c}\text { Normal } \\
\text { Design }\end{array}$ & $\begin{array}{c}\text { Compacted } \\
\text { Condition }\end{array}$ & $\begin{array}{c}\text { Raised } \\
\text { Condition }\end{array}$ & $\begin{array}{c}\text { Compacting } \\
\text { Sensitivity } \\
(\% / f t)\end{array}$ & $\begin{array}{c}\text { Height } \\
\text { Sensitivity } \\
\text { (\%/ft) }\end{array}$ \\
\hline Magnetic field & & & & & \\
0 & 135.1 & 133.1 & 119.4 & 0.30 & 2.32 \\
20 & 137.1 & 131.5 & 119 & 0.82 & 2.64 \\
40 & 124.6 & 112.7 & 107.5 & 1.91 & 2.74 \\
60 & 93.15 & 80.38 & 82.89 & 2.74 & 2.20 \\
80 & 63.23 & 53.82 & 58.48 & 2.98 & 1.50 \\
100 & 43.28 & 36.89 & 41.11 & 2.95 & 1.00 \\
120 & 30.86 & 26.42 & 29.79 & 2.88 & 0.69 \\
160 & 17.66 & 15.23 & 17.32 & 2.75 & 0.39 \\
200 & 11.35 & 9.832 & 11.21 & 2.67 & 0.25 \\
& & & & & \\
Electric field & & & & & \\
0 & 3.985 & 3.339 & 3.099 & 3.24 & 4.45 \\
20 & 3.989 & 3.997 & 3.384 & -0.04 & 3.03 \\
40 & 5.671 & 5.526 & 4.759 & 0.51 & 3.22 \\
60 & 5.132 & 4.53 & 4.51 & 2.35 & 2.42 \\
80 & 3.329 & 2.841 & 3.142 & 2.93 & 1.12 \\
100 & 2.001 & 1.708 & 1.991 & 2.93 & 0.10 \\
120 & 1.233 & 1.062 & 1.269 & 2.77 & -0.58 \\
160 & 0.54 & 0.474 & 0.575 & 2.44 & -1.30 \\
200 & 0.279 & 0.247 & 0.301 & 2.29 & -1.58 \\
\hline
\end{tabular}

a Calculated for a position $3 \mathrm{ft}$ above ground level at the point of maximum line sag between towers.

b Field strength data are in milligauss for the magnetic field and in kilovolts per meter for the electric field.

- Coordinates of grounded shield wires,

- Wire $1, x=-26 \mathrm{ft}$ and $y=57 \mathrm{ft}$,

- Wire $2, x=26 \mathrm{ft}$ and $y=57 \mathrm{ft}$; and

- Height of points of calculated EMFs (Table A.2) equals $3 \mathrm{ft}$ above ground level.

\section{A.2.2 Delta Configuration for $500-\mathrm{kV}$ ac}

For the 500-kV ac delta configuration (Figure 5), the following conditions and spacing were assumed for each of the calculations for baseline or nominal conditions; the coordinates 
TABLE A.2 Calculated EMF Strengths and Sensitivities for 500-kV ac Horizontal Configuration at 1,000 A per Phase

\begin{tabular}{cccccc}
\hline & \multicolumn{3}{c}{ Field Strength $^{\mathrm{b}}$} & & \\
\cline { 2 - 4 } $\begin{array}{c}\text { Distance from } \\
\text { Centerline (ft) }\end{array}$ & $\begin{array}{c}\text { Normal } \\
\text { Design }\end{array}$ & $\begin{array}{c}\text { Compacted } \\
\text { Condition }\end{array}$ & $\begin{array}{c}\text { Raised } \\
\text { Condition }\end{array}$ & $\begin{array}{c}\text { Compacting } \\
\text { Sensitivity } \\
(\% / f t)\end{array}$ & $\begin{array}{c}\text { Height } \\
\text { Sensitivity } \\
\text { (\%/ft) }\end{array}$ \\
\hline Magnetic field & & & & & \\
0 & 203.6 & 209.3 & 176.9 & -0.56 & 2.62 \\
20 & 226.4 & 219.7 & 185.4 & 0.59 & 3.62 \\
40 & 192.9 & 164.9 & 158.0 & 2.90 & 3.62 \\
60 & 113.7 & 92.49 & 101.1 & 3.73 & 2.22 \\
80 & 65.81 & 53.97 & 61.77 & 3.60 & 1.23 \\
100 & 41.77 & 34.67 & 40.24 & 3.40 & 0.73 \\
120 & 28.71 & 24.03 & 28.01 & 3.26 & 0.49 \\
160 & 15.92 & 13.46 & 15.72 & 3.09 & 0.25 \\
200 & 10.11 & 8.584 & 10.03 & 3.02 & 0.16 \\
& & & & & \\
Electric field & & & & & \\
0 & 5.443 & 4.754 & 3.943 & 2.53 & 5.51 \\
20 & 4.608 & 5.043 & 3.836 & -1.89 & 3.35 \\
40 & 6.831 & 6.130 & 5.439 & 2.05 & 4.08 \\
60 & 4.080 & 3.250 & 3.721 & 4.07 & 1.76 \\
80 & 1.938 & 1.544 & 1.963 & 4.07 & -0.26 \\
100 & 0.995 & 0.806 & 1.064 & 3.80 & -1.39 \\
120 & 0.567 & 0.466 & 0.623 & 3.56 & -1.98 \\
160 & 0.232 & 0.195 & 0.262 & 3.19 & -2.59 \\
200 & 0.117 & 0.099 & 0.133 & 3.08 & -2.74 \\
\hline
\end{tabular}

a Calculated for a position $3 \mathrm{ft}$ above ground level at the point of maximum line sag between towers.

b Field strength data are in milligauss for the magnetic field and in kilovolts per meter for the electric field.

of the three phases are specified in relation to the tower's centerline $(x=0 \mathrm{ft})$ and to ground level $(y=0 \mathrm{ft})$ :

- Coordinates of phase conductors,

- Phase A, $x=-15.33 \mathrm{ft}$ and $y=30 \mathrm{ft}$ (at sag point for the line considered),

- Phase $\mathrm{B}, x=0 \mathrm{ft}$ and $y=59.4 \mathrm{ft}$,

- Phase C, $x=15.33 \mathrm{ft}$ and $y=30 \mathrm{ft}$;

- Phase current of $1,000 \mathrm{~A}$;

- Minimum phase-to-ground distance (per NESC [IEEE 1990]) of $30 \mathrm{ft}$ (at conductor sag point); 
TABLE A.3 Calculated EMF Strengths and Sensitivities for 500-kV ac Delta Configuration at 1,000 A per Phase

\begin{tabular}{cccccc}
\hline & \multicolumn{3}{c}{ Field Strength $^{\mathrm{b}}$} & & \\
\cline { 2 - 5 } $\begin{array}{c}\text { Distance from } \\
\text { Centerline (ft) }\end{array}$ & $\begin{array}{c}\text { Normal } \\
\text { Design }\end{array}$ & $\begin{array}{c}\text { Compacted } \\
\text { Condition }\end{array}$ & $\begin{array}{c}\text { Raised } \\
\text { Condition }\end{array}$ & $\begin{array}{c}\text { Sensitivity } \\
(\% / \mathrm{ft})\end{array}$ & $\begin{array}{c}\text { Height } \\
\text { Sensitivity } \\
(\% / \mathrm{ft})\end{array}$ \\
\hline Magnetic field & & & & & \\
0 & 180.7 & 163.2 & 138.4 & 1.94 & 4.68 \\
20 & 147.7 & 127.1 & 115.9 & 2.79 & 4.31 \\
40 & 83.97 & 69.83 & 72.23 & 3.37 & 2.80 \\
60 & 46.65 & 38.69 & 42.74 & 3.41 & 1.68 \\
80 & 28.44 & 23.64 & 26.91 & 3.38 & 1.08 \\
100 & 18.85 & 15.70 & 18.15 & 3.34 & 0.74 \\
120 & 13.31 & 11.11 & 12.94 & 3.31 & 0.56 \\
160 & 7.577 & 6.348 & 7.455 & 3.24 & 0.32 \\
200 & 4.863 & 4.086 & 4.811 & 3.20 & 0.21 \\
& & & & & \\
Electric field & & & & & \\
0 & 3.732 & 3.866 & 3.234 & -0.72 & 2.67 \\
20 & 5.798 & 5.254 & 4.510 & 1.88 & 4.44 \\
40 & 3.392 & 2.836 & 3.058 & 3.28 & 1.97 \\
60 & 1.486 & 1.235 & 1.505 & 3.38 & -0.26 \\
80 & 0.724 & 0.612 & 0.768 & 3.09 & -1.22 \\
100 & 0.412 & 0.355 & 0.440 & 2.77 & -1.36 \\
120 & 0.266 & 0.232 & 0.281 & 2.56 & -1.13 \\
160 & 0.141 & 0.123 & 0.144 & 2.55 & -0.43 \\
200 & 0.088 & 0.077 & 0.089 & 2.50 & -0.23 \\
\hline
\end{tabular}

a Calculated for a position $3 \mathrm{ft}$ above ground level at the point of maximum line sag between towers.

b Field strength data are in milligauss for the magnetic field and in kilovolts per meter for the electric field.

- Coordinates of grounded shield wires,

- Wire $1, x=-12 \mathrm{ft}$ and $y=76 \mathrm{ft}$,

- Wire $2, x=12 \mathrm{ft}$ and $y=76 \mathrm{ft}$; and

- Height of points of calculated EMFs (Table A.3) equals $3 \mathrm{ft}$ above ground level.

\section{A.2.3 Vertical Configuration for $500-\mathrm{kV}$ ac}

For the $500-\mathrm{kV}$ ac vertical configuration (Figure 6), the following conditions and spacing were assumed for each of the calculations for baseline or nominal conditions; the coordinates of the three phases are specified in relation to the tower's centerline $(x=0 \mathrm{ft})$ and to ground level $(y=0 \mathrm{ft})$ : 
- Coordinates of phase conductors,

- Phase A, $x=18 \mathrm{ft}$ and $y=30 \mathrm{ft}$ (at sag point for the line considered),

- Phase $\mathrm{B}, x=22 \mathrm{ft}$ and $y=60 \mathrm{ft}$,

- Phase C, $x=18 \mathrm{ft}$ and $y=90 \mathrm{ft}$;

- Phase current of $1,000 \mathrm{~A}$;

- Minimum phase-to-ground distance (per NESC [IEEE 1990]) of $30 \mathrm{ft}$ (at conductor sag point);

- Coordinates of grounded shield wire,

- Wire $1, x=9 \mathrm{ft}$ and $y=123 \mathrm{ft}$; and

- Height of points of calculated EMFs (Table A.4) equals $3 \mathrm{ft}$ above ground level.

TABLE A.4 Calculated EMF Strengths and Sensitivities for 500-kV ac Vertical Configuration at 1,000 A per Phase

\begin{tabular}{cccccc}
\hline & \multicolumn{3}{c}{ Field Strength $^{\mathrm{b}}$} & & \\
\cline { 2 - 5 } $\begin{array}{c}\text { Distance from } \\
\text { Centerline (ft) }\end{array}$ & $\begin{array}{c}\text { Normal } \\
\text { Design }\end{array}$ & $\begin{array}{c}\text { Compacted } \\
\text { Condition }\end{array}$ & $\begin{array}{c}\text { Raised } \\
\text { Condition }\end{array}$ & $\begin{array}{c}\text { Compacting } \\
\text { Sensitivity } \\
(\% / f t)\end{array}$ & $\begin{array}{c}\text { Height } \\
\text { Sensitivity } \\
\text { (\%/ft) }\end{array}$ \\
\hline Magnetic field & & & & & \\
0 & 151.7 & 141.8 & 120.2 & 1.31 & 4.15 \\
20 & 117.8 & 109.4 & 99.01 & 1.43 & 3.19 \\
40 & 75.33 & 68.89 & 67.65 & 1.71 & 2.04 \\
60 & 49.55 & 44.56 & 46.13 & 2.01 & 1.38 \\
80 & 34.35 & 30.41 & 32.64 & 2.29 & 1.00 \\
100 & 24.90 & 21.77 & 23.97 & 2.51 & 0.75 \\
120 & 18.73 & 16.22 & 18.19 & 2.68 & 0.58 \\
160 & 11.54 & 9.865 & 11.33 & 2.90 & 0.36 \\
200 & 7.748 & 6.570 & 7.649 & 3.04 & 0.26 \\
& & & & & \\
Electric field & & & & & \\
0 & 6.531 & 6.224 & 5.239 & 0.94 & 3.96 \\
20 & 3.800 & 3.532 & 3.427 & 1.41 & 1.96 \\
40 & 1.212 & 1.031 & 1.316 & 2.99 & -1.72 \\
60 & 0.292 & 0.189 & 0.372 & 7.05 & -5.48 \\
80 & 0.217 & 0.220 & 0.139 & -0.28 & 7.19 \\
100 & 0.262 & 0.261 & 0.197 & 0.08 & 4.96 \\
120 & 0.258 & 0.248 & 0.215 & 0.78 & 3.33 \\
160 & 0.207 & 0.190 & 0.187 & 1.64 & 1.93 \\
200 & 0.156 & 0.140 & 0.146 & 2.05 & 1.28 \\
\hline
\end{tabular}

a Calculated for a position $3 \mathrm{ft}$ above ground level at the point of maximum line sag between towers.

b Field strength data are in milligauss for the magnetic field and in kilovolts per meter for the electric field. 


\section{A.2.4 Davit Configuration for $500-\mathrm{kV}$ ac}

For the 500-kV ac davit configuration (Figure 7), the following conditions and spacing were assumed for each of the calculations for baseline or nominal conditions; the coordinates of the three phases are specified in relation to the tower's centerline ( $x=0 \mathrm{ft}$ ) and to ground level $(y=0 \mathrm{ft})$ :

- Coordinates of phase conductors,

- Phase A, $x=-17 \mathrm{ft}$ and $y=42 \mathrm{ft}$ (at sag point for the line considered),

- Phase $\mathrm{B}, x=17 \mathrm{ft}$ and $y=55 \mathrm{ft}$,

- Phase C, $x=18 \mathrm{ft}$ and $y=30 \mathrm{ft}$;

- Phase current of $1,000 \mathrm{~A}$;

- Minimum phase-to-ground distance (per NESC [IEEE 1990]) of $30 \mathrm{ft}$ (at conductor sag point);

- Coordinates of grounded shield wires,

- Wire $1, x=-10 \mathrm{ft}$ and $y=74 \mathrm{ft}$,

- Wire $2, x=10 \mathrm{ft}$ and $y=74 \mathrm{ft}$; and

- Height of points of calculated EMFs (Table A.5) equals $3 \mathrm{ft}$ above ground level.

\section{A.2.5 Split-Phase Configuration for 500-kV ac}

For the 500-kV ac split-phase configuration (Figure 2), the following conditions and spacing were assumed for each of the calculations for baseline or nominal conditions; the coordinates of the three phases are specified in relation to the tower's centerline $(x=0 \mathrm{ft})$ and to ground level $(y=0 \mathrm{ft})$ :

- Coordinates of phase conductors,

- Phase A, $x=-15 \mathrm{ft}$ and $y=30 \mathrm{ft}$ (at sag point for the line considered),

- Phase B, $x=-25 \mathrm{ft}$ and $y=61 \mathrm{ft}$,

- Phase C, $x=-15 \mathrm{ft}$ and $y=92 \mathrm{ft}$,

- Phase D, $x=15 \mathrm{ft}$ and $y=92 \mathrm{ft}$,

- Phase E, $x=25 \mathrm{ft}$ and $y=61 \mathrm{ft}$,

- Phase F, $x=15 \mathrm{ft}$ and $y=30 \mathrm{ft}$;

- Phase current of $1,000 \mathrm{~A}$;

- Minimum phase-to-ground distance (per NESC [IEEE 1990]) of $30 \mathrm{ft}$ (at conductor sag point); 
TABLE A.5 Calculated EMF Strengths and Sensitivities for 500-kV ac Davit Configuration at $1,000 \mathrm{~A}$ per Phase

\begin{tabular}{cccccc}
\hline & \multicolumn{3}{c}{ Field Strength $^{\mathrm{b}}$} & & \\
\cline { 2 - 4 } $\begin{array}{c}\text { Distance from } \\
\text { Centerline (ft) }\end{array}$ & $\begin{array}{c}\text { Normal } \\
\text { Design }\end{array}$ & $\begin{array}{c}\text { Compacted } \\
\text { Condition }\end{array}$ & $\begin{array}{c}\text { Raised } \\
\text { Condition }\end{array}$ & $\begin{array}{c}\text { Compacting } \\
\text { Sensitivity } \\
(\% / f t)\end{array}$ & $\begin{array}{c}\text { Height } \\
\text { Sensitivity } \\
\text { (\%/ft) }\end{array}$ \\
\hline Magnetic field & & & & & \\
0 & 152.4 & 146.9 & 121.6 & 0.72 & 4.04 \\
20 & 145.9 & 131.1 & 114.6 & 2.03 & 4.29 \\
40 & 89.44 & 75.79 & 76.25 & 3.05 & 2.95 \\
60 & 49.54 & 41.83 & 45.34 & 3.11 & 1.70 \\
80 & 29.83 & 25.64 & 28.34 & 2.81 & 1.00 \\
100 & 19.76 & 17.25 & 19.12 & 2.54 & 0.65 \\
120 & 14.08 & 12.38 & 13.75 & 2.41 & 0.47 \\
160 & 8.209 & 7.230 & 8.094 & 2.39 & 0.28 \\
200 & 5.366 & 4.719 & 5.316 & 2.41 & 0.19 \\
& & & & & \\
Electric field & & & & & \\
0 & 2.805 & 2.844 & 2.483 & -0.28 & 2.30 \\
20 & 5.749 & 5.263 & 4.467 & 1.69 & 4.46 \\
40 & 3.492 & 2.951 & 3.112 & 3.10 & 2.18 \\
60 & 1.579 & 1.376 & 1.559 & 2.57 & 0.25 \\
80 & 0.865 & 0.765 & 0.866 & 2.31 & -0.02 \\
100 & 0.547 & 0.476 & 0.547 & 2.60 & 0.00 \\
120 & 0.371 & 0.318 & 0.372 & 2.86 & -0.05 \\
160 & 0.196 & 0.163 & 0.197 & 3.37 & -0.10 \\
200 & 0.117 & 0.096 & 0.118 & 3.59 & -0.17 \\
\hline
\end{tabular}

a Calculated for a position $3 \mathrm{ft}$ above ground level at the point of maximum line sag between towers.

b Field strength data are in milligauss for the magnetic field and in kilovolts per meter for the electric field.

- Coordinates of grounded shield wire,

- Wire $1, x=0 \mathrm{ft}$ and $y=127 \mathrm{ft}$; and

- Height of points of calculated EMFs (Table A.6) equals $3 \mathrm{ft}$ above ground level.

\section{A.3 CONFIGURATIONS FOR 345-kV ac}

Many different 345-kV ac configurations exist. For discussion purposes, the following were chosen to be representative of the group:

- Horizontal, 
TABLE A.6 Calculated EMF Strengths and Sensitivities for 500-kV ac Split-Phase Configuration at 1,000 A per Phase

\begin{tabular}{|c|c|c|c|c|c|}
\hline \multirow[b]{2}{*}{$\begin{array}{l}\text { Distance from } \\
\text { Centerline (ft) }\end{array}$} & \multicolumn{3}{|c|}{ Field Strength ${ }^{b}$} & \multirow{2}{*}{$\begin{array}{c}\text { Compacting } \\
\text { Sensitivity } \\
\text { (\%/ft) }\end{array}$} & \multirow{2}{*}{$\begin{array}{c}\text { Height } \\
\text { Sensitivity } \\
\text { (\%/ft) }\end{array}$} \\
\hline & $\begin{array}{l}\text { Normal } \\
\text { Design }\end{array}$ & $\begin{array}{l}\text { Compacted } \\
\text { Condition }\end{array}$ & $\begin{array}{c}\text { Raised } \\
\text { Condition }\end{array}$ & & \\
\hline \multicolumn{6}{|l|}{ Magnetic field } \\
\hline 0 & 157.8 & 138.3 & 117.7 & 2.47 & 5.08 \\
\hline 20 & 129.1 & 107.3 & 98.46 & 3.38 & 4.75 \\
\hline 40 & 73.04 & 57.58 & 60.70 & 4.23 & 3.38 \\
\hline 60 & 38.91 & 29.79 & 34.48 & 4.69 & 2.28 \\
\hline 80 & 21.99 & 16.52 & 20.24 & 4.97 & 1.59 \\
\hline 100 & 13.33 & 9.890 & 12.56 & 5.16 & 1.16 \\
\hline 120 & 8.604 & 6.328 & 8.228 & 5.29 & 0.87 \\
\hline 160 & 4.138 & 3.001 & 4.023 & 5.50 & 0.56 \\
\hline 200 & 2.277 & 1.634 & 2.233 & 5.65 & 0.39 \\
\hline \multicolumn{6}{|l|}{ Electric field } \\
\hline 0 & 3.337 & 3.354 & 2.785 & -0.10 & 3.31 \\
\hline 20 & 5.121 & 4.439 & 3.878 & 2.66 & 4.85 \\
\hline 40 & 2.591 & 2.023 & 2.315 & 4.38 & 2.13 \\
\hline 60 & 1.071 & 0.853 & 1.023 & 4.07 & 0.90 \\
\hline 80 & 0.617 & 0.483 & 0.566 & 4.34 & 1.65 \\
\hline 100 & 0.399 & 0.302 & 0.365 & 4.86 & 1.70 \\
\hline 120 & 0.268 & 0.200 & 0.248 & 5.07 & 1.49 \\
\hline 160 & 0.136 & 0.100 & 0.128 & 5.29 & 1.18 \\
\hline 200 & 0.078 & 0.057 & 0.074 & 5.38 & 1.03 \\
\hline
\end{tabular}

a Calculated for a position $3 \mathrm{ft}$ above ground level at the point of maximum line sag between towers.

b Field strength data are in milligauss for the magnetic field and in kilovolts per meter for the electric field.

- Delta,

- Davit, and

- Split phase.

\section{A.3.1 Horizontal Configuration for $345-\mathrm{kV}$ ac}

For the 345-kV ac horizontal configuration (Figure 8), the following conditions and spacing were assumed for each of the calculations for baseline or nominal conditions; the 
coordinates of the three phases are specified in relation to the tower's centerline $(x=0 \mathrm{ft})$ and to ground level $(y=0 \mathrm{ft})$ :

- Coordinates of phase conductors,

- Phase A, $x=-22.7 \mathrm{ft}$ and $y=30 \mathrm{ft}$ (at sag point for the line considered),

- Phase $\mathrm{B}, x=0 \mathrm{ft}$ and $y=30 \mathrm{ft}$,

- Phase C, $x=22.7 \mathrm{ft}$ and $y=30 \mathrm{ft}$;

- Phase current of $1,000 \mathrm{~A}$;

- Minimum phase-to-ground distance (per NESC [IEEE 1990]) of $30 \mathrm{ft}$ (at conductor sag point);

- Coordinates of grounded shield wires,

- Wire $1, x=-18.6 \mathrm{ft}$ and $y=48 \mathrm{ft}$,

- Wire 2, $x=18.6 \mathrm{ft}$ and $y=48 \mathrm{ft}$; and

- Height of points of calculated EMFs (Table A.7) equals $3 \mathrm{ft}$ above ground level.

\section{A.3.2 Delta Configuration for $345-\mathrm{kV}$ ac}

For the $345-\mathrm{kV}$ ac delta configuration (Figure 9), the following conditions and spacing were assumed for each of the calculations for baseline or nominal conditions; the coordinates of the three phases are specified in relation to the tower's centerline $(x=0 \mathrm{ft})$ and to ground level $(y=0 \mathrm{ft})$ :

- Coordinates of phase conductors,

- Phase A, $x=-13.5 \mathrm{ft}$ and $y=30 \mathrm{ft}$ (at sag point for the line considered),

- Phase $\mathrm{B}, x=0 \mathrm{ft}$ and $y=50.3 \mathrm{ft}$,

- Phase C, $x=13.5 \mathrm{ft}$ and $y=30 \mathrm{ft}$;

- Phase current of $1,000 \mathrm{~A}$;

- Minimum phase-to-ground distance (per NESC [LEEE 1990]) of $30 \mathrm{ft}$ (at conductor sag point);

- Coordinates of grounded shield wires,

- Wire $1, x=-8 \mathrm{ft}$ and $y=59 \mathrm{ft}$,

- Wire 2, $x=8 \mathrm{ft}$ and $y=59 \mathrm{ft}$; and

- Height of points of calculated EMFs (Table A.8) equals $3 \mathrm{ft}$ above ground level. 
TABLE A.7 Calculated EMF Strengths and Sensitivities for 345-kV ac Horizontal Configuration at 1,000 A per Phase

\begin{tabular}{cccccc}
\hline & \multicolumn{3}{c}{ Field Strength $^{\mathrm{b}}$} & & \\
\cline { 2 - 4 } $\begin{array}{c}\text { Distance from } \\
\text { Centerline (ft) }\end{array}$ & $\begin{array}{c}\text { Normal } \\
\text { Design }\end{array}$ & $\begin{array}{c}\text { Compacted } \\
\text { Condition }\end{array}$ & $\begin{array}{c}\text { Raised } \\
\text { Condition }\end{array}$ & $\begin{array}{c}\text { Sensitivity } \\
\text { (\%/ft) }\end{array}$ & $\begin{array}{c}\text { Height } \\
\text { Sensitivity } \\
\text { (\%/ft) }\end{array}$ \\
\hline Magnetic field & & & & \\
0 & 207.3 & 193.0 & 167.6 & 1.38 & 3.83 \\
20 & 193.7 & 162.9 & 153.3 & 3.18 & 4.17 \\
40 & 120.9 & 91.57 & 102.8 & 4.85 & 2.99 \\
60 & 65.46 & 49.22 & 60.06 & 4.96 & 1.65 \\
80 & 38.77 & 29.42 & 36.91 & 4.82 & 0.96 \\
100 & 25.27 & 19.32 & 24.49 & 4.71 & 0.62 \\
120 & 17.69 & 13.59 & 17.31 & 4.64 & 0.43 \\
160 & 10.02 & 7.742 & 9.897 & 4.55 & 0.25 \\
200 & 6.426 & 4.982 & 6.378 & 4.49 & 0.15 \\
& & & & & \\
Electric field & & & & & \\
0 & 2.380 & 1.630 & 1.573 & 6.30 & 6.78 \\
20 & 3.653 & 3.464 & 2.768 & 1.03 & 4.85 \\
40 & 3.184 & 2.467 & 2.685 & 4.50 & 3.13 \\
60 & 1.523 & 1.142 & 1.479 & 5.00 & 0.58 \\
80 & 0.732 & 0.556 & 0.767 & 4.81 & -0.96 \\
100 & 0.392 & 0.302 & 0.427 & 4.59 & -1.79 \\
120 & 0.231 & 0.180 & 0.257 & 4.42 & -2.25 \\
160 & 0.099 & 0.078 & 0.113 & 4.24 & -2.83 \\
200 & 0.051 & 0.041 & 0.059 & 3.92 & -3.14 \\
\hline
\end{tabular}

a Calculated for a position $3 \mathrm{ft}$ above ground level at the point of maximum line sag between towers.

b Field strength data are in milligauss for the magnetic field and in kilovolts per meter for the electric field.

\section{A.3.3 Davit Configuration for 345-kV ac}

For the $345-\mathrm{kV}$ ac davit configuration (Figure 10), the following conditions and spacing were assumed for each of the calculations for baseline or nominal conditions; the coordinates of the three phases are specified in relation to the tower's centerline $(x=0 \mathrm{ft})$ and to ground level $(y=0 \mathrm{ft})$ :

- Coordinates of phase conductors,

- Phase A, $x=-9 \mathrm{ft}$ and $y=41.5 \mathrm{ft}$ (at sag point for the line considered),

- Phase B, $x=9 \mathrm{ft}$ and $y=53 \mathrm{ft}$,

- Phase C, $x=9 \mathrm{ft}$ and $y=30 \mathrm{ft}$;

- Phase current of $1,000 \mathrm{~A}$; 
TABLE A.8 Calculated EME Strengths and Sensitivities for 345-kV ac Delta Configuration at 1,000 A per Phase

\begin{tabular}{cccccc}
\hline & \multicolumn{5}{c}{ Field Strength $^{\mathrm{b}}$} \\
$\begin{array}{c}\text { Distance from } \\
\text { Centerline (ft) }\end{array}$ & $\begin{array}{c}\text { Normal } \\
\text { Design }\end{array}$ & $\begin{array}{c}\text { Compacted } \\
\text { Condition }\end{array}$ & $\begin{array}{c}\text { Raised } \\
\text { Condition }\end{array}$ & $\begin{array}{c}\text { Compacting } \\
\text { Sensitivity } \\
(\% / \mathrm{ft})\end{array}$ & $\begin{array}{c}\text { Height } \\
\text { Sensitivity } \\
(\% / \mathrm{ft})\end{array}$ \\
\hline Magnetic field & & & & & \\
0 & 168.4 & 147.1 & 127.2 & 2.53 & 4.89 \\
20 & 131.2 & 108.9 & 103.1 & 3.40 & 4.28 \\
40 & 70.91 & 56.77 & 61.50 & 3.99 & 2.65 \\
60 & 38.45 & 30.62 & 35.50 & 4.07 & 1.53 \\
80 & 23.11 & 18.43 & 22.02 & 4.05 & 0.94 \\
100 & 15.19 & 12.13 & 14.71 & 4.03 & 0.63 \\
120 & 10.66 & 8.537 & 10.43 & 3.98 & 0.43 \\
160 & 6.040 & 4.854 & 5.964 & 3.93 & 0.25 \\
200 & 3.868 & 3.118 & 3.837 & 3.88 & 0.16 \\
& & & & & \\
Electric field & & & & & \\
0 & 2.442 & 2.432 & 2.090 & 0.08 & 2.88 \\
20 & 3.677 & 3.224 & 2.857 & 2.46 & 4.46 \\
40 & 2.062 & 1.695 & 1.875 & 3.56 & 1.81 \\
60 & 0.906 & 0.744 & 0.923 & 3.58 & -0.38 \\
80 & 0.441 & 0.365 & 0.472 & 3.45 & -1.41 \\
100 & 0.244 & 0.203 & 0.266 & 3.36 & -1.80 \\
120 & 0.151 & 0.126 & 0.165 & 3.31 & -1.85 \\
160 & 0.073 & 0.059 & 0.078 & 3.84 & -1.37 \\
200 & 0.042 & 0.034 & 0.044 & 3.81 & -0.95 \\
\hline
\end{tabular}

a Calculated for a position $3 \mathrm{ft}$ above ground level at the point of maximum line sag between towers.

b Field strength data are in milligauss for the magnetic field and in kilovolts per meter for the electric field.

- Minimum phase-to-ground distance (per NESC [IEEE 1990]) of $30 \mathrm{ft}$ (at conductor sag point);

- Coordinates of grounded shield wire,

- Wire $1, x=0 \mathrm{ft}$ and $y=86.5 \mathrm{ft}$; and

- Height of points of calculated EMFs (Table A.9) equals $3 \mathrm{ft}$ above ground level. 
TABLE A.9 Calculated EMF Strengths and Sensitivities for 345-kV ac Davit Configuration at 1,000 A per Phase

\begin{tabular}{cccccc}
\hline & \multicolumn{3}{c}{ Field Strength $^{\mathrm{b}}$} & & \\
\cline { 2 - 4 } $\begin{array}{c}\text { Distance from } \\
\text { Centerline (ft) }\end{array}$ & $\begin{array}{c}\text { Normal } \\
\text { Design }\end{array}$ & $\begin{array}{c}\text { Compacted } \\
\text { Condition }\end{array}$ & $\begin{array}{c}\text { Raised } \\
\text { Condition }\end{array}$ & $\begin{array}{c}\text { Compacting } \\
\text { Sensitivity } \\
\text { (\%/ft) }\end{array}$ & $\begin{array}{c}\text { Height } \\
\text { Sensitivity } \\
\text { (\%/ft) }\end{array}$ \\
\hline Magnetic field & & & & & \\
0 & 111.5 & 95.86 & 85.09 & 2.81 & 4.74 \\
20 & 96.34 & 78.49 & 75.69 & 3.71 & 4.29 \\
40 & 56.15 & 44.19 & 48.44 & 4.26 & 2.75 \\
60 & 32.24 & 25.02 & 29.50 & 4.48 & 1.70 \\
80 & 19.98 & 15.41 & 18.87 & 4.57 & 1.11 \\
100 & 13.32 & 10.25 & 12.81 & 4.61 & 0.77 \\
120 & 9.422 & 7.250 & 9.162 & 4.61 & 0.55 \\
160 & 5.362 & 4.131 & 5.276 & 4.59 & 0.32 \\
200 & 3.434 & 2.649 & 3.398 & 4.57 & 0.21 \\
& & & & & \\
Electric field & & & & & 3.89 \\
0 & 2.702 & 2.542 & 2.177 & 1.18 & 3.86 \\
20 & 2.972 & 2.467 & 2.398 & 3.40 & 0.94 \\
40 & 1.272 & 1.028 & 1.212 & 3.84 & 0.40 \\
60 & 0.605 & 0.516 & 0.593 & 2.94 & 0.83 \\
80 & 0.385 & 0.328 & 0.369 & 2.96 & 0.81 \\
100 & 0.270 & 0.225 & 0.259 & 3.33 & 0.61 \\
120 & 0.196 & 0.162 & 0.190 & 3.47 & 0.35 \\
160 & 0.114 & 0.092 & 0.112 & 3.86 & 0.27 \\
200 & 0.073 & 0.059 & 0.072 & 3.84 & \\
\hline
\end{tabular}

a Calculated for a position $3 \mathrm{ft}$ above ground level at the point of maximum line sag between towers.

b Field strength data are in milligauss for the magnetic field and in kilovolts per meter for the electric field.

\section{A.3.4 Split-Phase Configuration for $345-\mathrm{kV}$ ac}

For the 345-kV ac split-phase configuration (Figure 11), the following conditions and spacing were assumed for each of the calculations for baseline or nominal conditions; the coordinates of the three phases are specified in relation to the tower's centerline $(x=0 \mathrm{ft})$ and to ground level $(y=0 \mathrm{ft})$ :

- Coordinates of phase conductors,

- Phase A, $x=-16.5 \mathrm{ft}$ and $y=30 \mathrm{ft}$ (at sag point for the line considered),

- Phase $\mathrm{B}, x=-25 \mathrm{ft}$ and $y=46 \mathrm{ft}$,

- Phase C, $x=-15 \mathrm{ft}$ and $y=66 \mathrm{ft}$,

- Phase D, $x=15 \mathrm{ft}$ and $y=66 \mathrm{ft}$,

- Phase E, $x=25 \mathrm{ft}$ and $y=46 \mathrm{ft}$,

- Phase F, $x=16.5 \mathrm{ft}$ and $y=30 \mathrm{ft}$; 
- Phase current of $1,000 \mathrm{~A}$;

- Minimum phase-to-ground distance (per NESC [IEEE 1990]) of $30 \mathrm{ft}$ (at conductor sag point);

- Coordinates of grounded shield wires,

- Wire $1, x=-20 \mathrm{ft}$ and $y=78 \mathrm{ft}$,

- Wire $2, x=20 \mathrm{ft}$ and $y=78 \mathrm{ft}$; and

- Height of points of calculated EMFs (Table A.10) equals $3 \mathrm{ft}$ above ground level.

\section{A.4 HORIZONTAL CONFIGURATION FOR $\pm 450-\mathrm{kV}$ de}

For the $\pm 450-\mathrm{kV}$ dc configuration (Figure 12), the following conditions and spacing were assumed for each of the calculations for baseline or nominal conditions; the coordinates of the two conductors are specified in relation to the tower's centerline $(x=0 \mathrm{ft})$ and to ground level $(y=0 \mathrm{ft})$ :

- Coordinates of two conductors,

- Conductor A, $x=-20 \mathrm{ft}$ and $y=30 \mathrm{ft}$ (at sag point for the line considered),

- Conductor B, $x=20 \mathrm{ft}$ and $y=30 \mathrm{ft}$;

- Conductor current of $1,000 \mathrm{~A}$;

- Minimum conductor-to-ground distance (per NESC [IEEE 1990]) of $30 \mathrm{ft}$ (at conductor sag point);

- Coordinates of grounded shield wire,

- Wire $1, x=0 \mathrm{ft}$ and $y=60 \mathrm{ft}$; and

- Height of points of calculated EMFs (Table A.11) equals $3 \mathrm{ft}$ above ground level.

\section{A.5 REFERENCES FOR APPENDIX A}

General Electric Co., 1982, Transmission Line Reference Book: $345 \mathrm{kV}$ and Above, 2nd ed., Electric Power Research Institute, Palo Alto, Calif.

IEEE: See Institute of Electrical and Electronics Engineers, Inc.

Institute of Electrical and Electronics Engineers, Inc., 1990, National Electrical Safety Code, New York, N.Y., Feb. 
TABLE A.10 Calculated EMF Strengths and Sensitivities for 345-kV ac Split-Phase Configuration at 1,000 A per Phase

\begin{tabular}{|c|c|c|c|c|c|}
\hline \multirow[b]{2}{*}{$\begin{array}{l}\text { Distance from } \\
\text { Centerline }(\mathrm{ft})^{\mathrm{a}}\end{array}$} & \multicolumn{3}{|c|}{ Field Strength ${ }^{b}$} & \multirow{2}{*}{$\begin{array}{c}\text { Compacting } \\
\text { Sensitivity } \\
(\% / f t)\end{array}$} & \multirow{2}{*}{$\begin{array}{c}\text { Height } \\
\text { Sensitivity } \\
(\% / f t)\end{array}$} \\
\hline & $\begin{array}{l}\text { Normal } \\
\text { Design }\end{array}$ & $\begin{array}{l}\text { Compacted } \\
\text { Condition }\end{array}$ & $\begin{array}{c}\text { Raised } \\
\text { Condition }\end{array}$ & & \\
\hline \multicolumn{6}{|l|}{ Magnetic field } \\
\hline 0 & 146.6 & 124.1 & 109.5 & 3.07 & 5.06 \\
\hline 20 & 120.7 & 95.66 & 91.36 & 4.15 & 4.86 \\
\hline 40 & 65.16 & 47.97 & 54.09 & 5.28 & 3.40 \\
\hline 60 & 32.69 & 23.82 & 29.20 & 5.43 & 2.14 \\
\hline 80 & 18.01 & 13.05 & 16.70 & 5.51 & 1.45 \\
\hline 100 & 10.81 & 7.796 & 10.24 & 5.58 & 1.05 \\
\hline 120 & 6.938 & 5.006 & 6.670 & 5.57 & 0.77 \\
\hline 160 & 3.338 & 2.434 & 3.261 & 5.42 & 0.46 \\
\hline 200 & 1.865 & 1.383 & 1.837 & 5.17 & 0.30 \\
\hline \multicolumn{6}{|l|}{ Electric field } \\
\hline 0 & 1.683 & 1.676 & 1.371 & 0.03 & 3.71 \\
\hline 20 & 3.166 & 2.562 & 2.336 & 3.82 & 5.24 \\
\hline 40 & 1.636 & 1.376 & 1.434 & 4.40 & 2.47 \\
\hline 60 & 0.713 & 0.627 & 0.666 & 2.41 & 1.32 \\
\hline 80 & 0.370 & 0.324 & 0.350 & 2.49 & 1.08 \\
\hline 100 & 0.209 & 0.180 & 0.201 & 2.78 & 0.77 \\
\hline 120 & 0.128 & 0.108 & 0.124 & 3.13 & 0.63 \\
\hline 160 & 0.058 & 0.047 & 0.057 & 3.79 & $0^{c}$ \\
\hline 200 & 0.031 & 0.025 & 0.030 & 3.84 & $0^{c}$ \\
\hline
\end{tabular}

a Calculated for a position $3 \mathrm{ft}$ above ground level at the point of maximum line sag between towers.

b Field strength data are in milligauss for the magnetic field and in kilovolts per meter for the electric field.

.c Field differences were too small for meaningful results. 
TABLE A.11 Calculated EMF Strengths and Sensitivities for $\pm 450-\mathrm{kV}$ dc Horizontal Configuration at 1,000 A per Phase

\begin{tabular}{cccccc}
\hline & \multicolumn{3}{c}{ Field Strength $^{\mathrm{b}}$} & & \\
\cline { 2 - 4 } $\begin{array}{c}\text { Distance from } \\
\text { Centerline (ft) }\end{array}$ & $\begin{array}{c}\text { Normal } \\
\text { Design }\end{array}$ & $\begin{array}{c}\text { Compacted } \\
\text { Condition }\end{array}$ & $\begin{array}{c}\text { Raised } \\
\text { Condition }\end{array}$ & $\begin{array}{c}\text { Compacting } \\
\text { Sensitivity } \\
\text { (\%/ft) }\end{array}$ & $\begin{array}{c}\text { Height } \\
\text { Sensitivity } \\
\text { (\%/ft) }\end{array}$ \\
\hline Magnetic field & & & & & \\
0 & 232.5 & 221.8 & 184.3 & 0.92 & 4.15 \\
20 & 201.4 & 183.3 & 160.1 & 1.80 & 4.10 \\
40 & 118.7 & 102.9 & 102.3 & 2.66 & 2.76 \\
60 & 64.41 & 55.58 & 59.47 & 2.74 & 1.53 \\
80 & 38.51 & 33.34 & 36.76 & 2.69 & 0.91 \\
100 & 25.27 & 21.94 & 24.53 & 2.64 & 0.59 \\
120 & 17.77 & 15.46 & 17.41 & 2.60 & 0.41 \\
160 & 10.11 & 8.819 & 9.997 & 2.55 & 0.22 \\
200 & 6.506 & 5.680 & 6.458 & 2.54 & 0.15 \\
& & & & & \\
Electric field & & & & & \\
0 & 2.185 & 2.258 & 1.622 & -0.67 & 5.15 \\
20 & 11.11 & 10.61 & 8.353 & 0.90 & 4.96 \\
40 & 8.408 & 7.375 & 7.276 & 2.46 & 2.69 \\
60 & 4.023 & 3.487 & 3.954 & 2.66 & 0.34 \\
80 & 1.995 & 1.737 & 2.095 & 2.59 & -1.00 \\
100 & 1.095 & 0.958 & 1.190 & 2.50 & -1.74 \\
120 & 0.657 & 0.577 & 0.728 & 2.44 & -2.16 \\
160 & 0.287 & 0.253 & 0.324 & 2.37 & -2.58 \\
200 & 0.149 & 0.132 & 0.170 & 2.28 & -2.82 \\
\hline
\end{tabular}

a Calculated for a position $3 \mathrm{ft}$ above ground level at the point of maximum line sag between towers.

b Field strength data are in milligauss for the magnetic field and in kilovolts per meter for the electric field. 


\section{APPENDIX B:}

\section{DESIGN AND CONSTRUCTION COST DATA}

Many state governments and utilities have taken a proactive position toward the mitigation of EMFs by developing public outreach programs and improving communication within their states and service areas. Only a few studies of mitigation have thus far been published. The cost data in the tables in Appendix B were developed by Commonwealth Associates, Inc. (1992), of Jackson, Michigan, for the state of Rhode Island; by Oppel and Stewart (1993) of Power Technologies, Inc., of Schenectady, New York, for the state of Florida; and by Waller and Geissinger (1992) of the Electric Transmission Research Needs Task Force for the state of Washington's Department of Health. These three studies are believed to contain the most current and comprehensive data on design and construction costs. Costs for right-of-way acquisition are significant and are not included in the cost data. While costs for right-of-way acquisition vary from location to location, Baltimore Gas and Electric (E.H. Bauman, personal communication, Baltimore, Md., 1993) estimated that rightof-way acquisition in its densely populated service area adds an additional $100-200 \%$ to construction costs.

Note that mitigative configurations and associated costs are necessarily specific to a site. The Rhode Island study (Commonwealth Associates, Inc. 1992) did not address designs and costs for $500-\mathrm{kV}$ transmission lines because none of these lines are planned for that state. Moreover, Rhode Island utilities tend to build multiple circuits on the same rightof-way and have many rights-of-way that are $200-300 \mathrm{ft}$ wide, with typical magnetic fields of between 1 and $28 \mathrm{mG}$ at the edge of the right-of-way. In developing designs and costs, the Florida study (Oppel and Stewart 1993) addressed three concerns considered specific to Florida: (1) the need to protect insulators from sea salt contamination; (2) the high incidence of lightning; and (3) high winds, especially from hurricanes.

\section{B.1 FLORIDA STATE STUDY}

The stated purpose for the study undertaken by Power Technologies, Inc., for the state of Florida was "to analyze options and propose designs to further reduce the magnetic fields beyond the present Florida designs" (Oppel and Stewart 1993, p. i). The study evaluated presently preferred $230-\mathrm{kV}$ and $500-\mathrm{kV}$ Florida transmission-line conductor configurations and towers to determine their electrical performance characteristics and identified the design with the lowest resulting magnetic fields. The study proposed two new $230-\mathrm{kV}$ and two new 500-kV designs and presented their design characteristics and costs. 


\section{B.1.1 Designs for $230-\mathrm{kV}$ ac}

Table B.1 provides construction costs and calculated EMF strengths for the proposed inverted-delta and split-phase 230-kV designs (Figures 16 and 17). These designs were compared to the currently used vertical design (Figure 15), which served as the base case. The study (Oppel and Stewart 1993) identified the following benefits and disadvantages of the proposed designs:

- Benefits of the proposed $230-\mathrm{kV}$ inverted-delta design,

- Magnetic field at $50 \mathrm{ft}$ from the tower's center that is one-half of the magnetic field level of the presently used $230-\mathrm{kV}$ design,

- Electric field strengths, audible noise, and radio noise within the same range as present $230-\mathrm{kV}$ vertical designs,

- Low impedance resulting in small voltage drop,

- Small phase impedance imbalance,

- Good lightning performance and reduced probability of flashovers caused by lightning strokes,

- Compact configuration with single-pole tower viable for city application,

- Less visual impact than a two-pole H-frame support;

TABLE B.1 Calculated EMF Strengths versus Construction Cost Data from the Florida Study for 230-kV Transmission Lines

\begin{tabular}{|c|c|c|c|c|c|c|c|}
\hline \multirow[b]{2}{*}{$\begin{array}{c}\text { Proposed } \\
\text { Design }\end{array}$} & \multirow[b]{2}{*}{$\begin{array}{l}\text { Construction } \\
\text { Cost per } \\
\text { Mile }\left(10^{3} \$\right)^{\mathrm{a}}\end{array}$} & \multicolumn{3}{|c|}{ Magnetic Field (mG) } & \multicolumn{3}{|c|}{ Electric Field (kV/m) } \\
\hline & & $\begin{array}{l}\text { Maximum } \\
\text { in Right- } \\
\text { of-Way }\end{array}$ & $\begin{array}{c}>50 \mathrm{ft} \\
\text { from } \\
\text { Centerline }\end{array}$ & $\begin{array}{c}<50 \mathrm{ft} \\
\text { from } \\
\text { Centerline }\end{array}$ & $\begin{array}{l}\text { Maximum } \\
\text { in Right- } \\
\text { of-Way }\end{array}$ & $\begin{array}{c}>50 \mathrm{ft} \\
\text { from } \\
\text { Centerline }\end{array}$ & $\begin{array}{c}<50 \mathrm{ft} \\
\text { from } \\
\text { Centerline }\end{array}$ \\
\hline $\begin{array}{l}\text { Vertical } \\
\text { (base case) }\end{array}$ & 120 & 111.7 & 34.1 & 21.2 & 2.80 & 0.06 & 0.10 \\
\hline $\begin{array}{l}\text { Inverted } \\
\text { delta }\end{array}$ & 175 & 85.86 & 17.6 & 17.6 & 2.36 & 0.38 & 0.38 \\
\hline Split phase & 198 & 51.13 & 7.02 & 7.02 & 1.92 & 0.11 & 0.11 \\
\hline
\end{tabular}

a Source: Oppel and Stewart (1993). 
- Disadvantages of the proposed $230-\mathrm{kV}$ inverted-delta design,

- Large-diameter conductors required to reduce corona-related effects, requiring larger, stronger, and more costly towers,

- Towers costly to manufacture because of the Y-shape and also possibly more difficult to erect than a single-pole support,

- Live-line maintenance more difficult and costly because of less phase-to-phase space,

- Higher visual impact,

- More right-of-way required;

- Benefits of the proposed $230-\mathrm{kV}$ split-phase design,

- Better EMF performance (or lower EMFs),

- Audible and radio noise levels within the same range as present $230-\mathrm{kV}$ vertical designs,

- Easy to maintain with present tools and techniques,

- Minimum impedance for improved surge loading and improved power transfer,

- Minimal phase impedance imbalance helpful for longer rural lines,

- Good lightning performance and reduced probability of flashovers caused by lightning strokes,

- Compact configuration with single-pole tower allowing city installation on narrow rights-of-way,

- Lowest magnetic fields with the least departure from present utility practices,

- Magnetic fields that decay faster than magnetic fields from the other designs;

- Disadvantages of the proposed $230-\mathrm{kV}$ split-phase design,

- Six phase conductors, plus two ground wires, with associated hardware and insulators increasing cost,

- Stronger, more costly towers required; and

- Higher visual impact. 


\section{B.1.2 Designs for $500-\mathrm{kV}$ ac}

Table B.2 lists the construction costs and calculated EMF strengths for two proposed $500-\mathrm{kV}$ designs. These data were compared with the same data for the currently used vertical design. The Florida study (Oppel and Stewart 1993) characterized the benefits and disadvantages of the proposed $500-\mathrm{kV}$ designs as follows:

- Benefits of the proposed inverted-delta and split-phase designs,

- Magnetic fields at $100 \mathrm{ft}$ from the tower's center that are less than those of the present vertical configuration,

- Electric field, audible noise, and radio noise within the range of present $500-\mathrm{kV}$ vertical design,

- Favorable impedance balance,

- Lower visual impact for tubular steel towers compared with steel lattice towers of the present $500-\mathrm{kV}$ horizontal configurations,

- Improved aesthetics because of shorter towers;

- Disadvantages of the proposed design,

- Tower foundations more costly than those for the present Florida vertical configuration,

- Increased difficulty of live-line maintenance, and

- Wider rights-of-way required.

TABLE B.2 Calculated EMF Strengths versus Construction Cost Data from the Florida Study for 500-kV Transmission Lines

\begin{tabular}{|c|c|c|c|c|c|c|c|}
\hline \multirow[b]{2}{*}{$\begin{array}{c}\text { Proposed } \\
\text { Design }\end{array}$} & \multirow[b]{2}{*}{$\begin{array}{l}\text { Construction } \\
\text { Cost per } \\
\text { Mile }\left(10^{3} \$\right)^{\mathrm{a}}\end{array}$} & \multicolumn{3}{|c|}{ Magnetic Field (mG) } & \multicolumn{3}{|c|}{ Electric Field $(\mathrm{kV} / \mathrm{m})$} \\
\hline & & $\begin{array}{l}\text { Maximum } \\
\text { in Right- } \\
\text { of-Way }\end{array}$ & $\begin{array}{c}>50 \mathrm{ft} \\
\text { from } \\
\text { Centerline }\end{array}$ & $\begin{array}{c}<50 \mathrm{ft} \\
\text { from } \\
\text { Centerline }\end{array}$ & $\begin{array}{l}\text { Maximum } \\
\text { in Right- } \\
\text { of-Way }\end{array}$ & $\begin{array}{c}>50 \mathrm{ft} \\
\text { from } \\
\text { Centerline }\end{array}$ & $\begin{array}{c}<50 \mathrm{ft} \\
\text { from } \\
\text { Centerline }\end{array}$ \\
\hline $\begin{array}{l}\text { Vertical } \\
\text { (base case) }\end{array}$ & 534 & 127.5 & 26.16 & 26.16 & 9.02 & 0.21 & 0.21 \\
\hline Delta & 593 & 144.0 & 22.71 & 22.71 & 8.14 & 0.81 & 0.81 \\
\hline Davit & 606 & 121.0 & 23.23 & 18.31 & 8.46 & 0.88 & 1.08 \\
\hline
\end{tabular}

a Source: Oppel and Stewart (1993). 


\section{B.2 RHODE ISLAND STATE STUDY}

The purpose of this study undertaken by Commonwealth Associates, Inc. (1992) for the state of Rhode Island was to determine the relative cost-effectiveness of various design options to reduce human exposure to EMFs from high-voltage transmission lines. The scope of the study was limited to electric power transmission at 345 and $115 \mathrm{kV}$.

The following features were assumed for the $345-\mathrm{kV}$ designs:

- 150-ft rights-of-way for overhead lines,

- 50-ft rights-of-way for underground cables,

- 500-A current,

- H-frame design span length of $800 \mathrm{ft}$,

- Davit-arm design span length of $600 \mathrm{ft}$,

- Compact delta design span length of $700 \mathrm{ft}$,

- Minimum ground clearance of $30 \mathrm{ft}$, and

- $\quad$ Phase spacing of $26 \mathrm{ft}$.

Table B. 3 presents the cost and calculated magnetic field strength data for the $345-\mathrm{kV}$ level.

The Rhode Island study (Commonwealth Associates, Inc. 1992) concluded the following for $345-\mathrm{kV}$ transmission:

- Additional reduction of the magnetic fields can be achieved by using a six-wire design but at a $36 \%$ increase in construction cost;

- For overhead transmission, magnetic fields at the edge of a right-of-way can be reduced by $45 \%$ (compared with those of the existing $\mathrm{H}$-frame design) by using the compact delta configuration but at a $20 \%$ increase in construction cost;

- For overhead transmission, magnetic fields at the edge of the 150-ft right-of-way can be reduced by $75 \%$ compared with existing $\mathrm{H}$-frame designs by using a six-wire configuration but at a $40 \%$ increase in cost; and

- Underground transmission provides an even greater reduction in magnetic fields but at a 3.7-fold increase in cost. 
TABLE B.3 Calculated Magnetic Field versus Construction Cost Data from the Rhode Island Study for 345-kV Transmission Lines

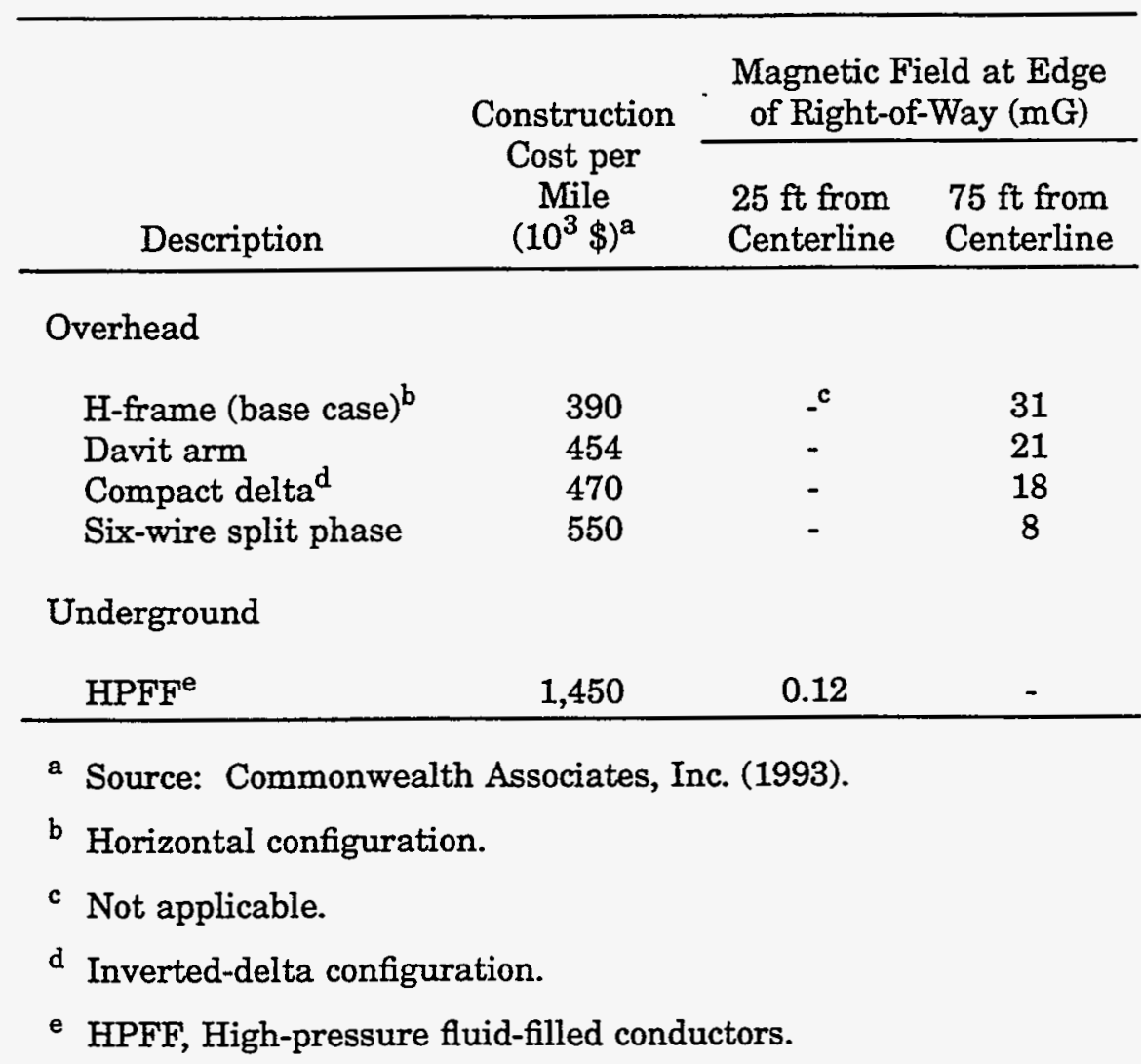

\section{B.3 WASHINGTON STATE STUDY}

The instructions to the Electric Transmission Research Needs Task Force of the State of Washington were as follows:

1. Recommend research needs for limiting human exposure to EMFs resulting from the transmission and distribution of electric power, focusing on engineering techniques and other ways to limit exposure;

2. Recommend options for funding needed research that is identified; and

3. Recommend options for legislative action.

The report Electric and Magnetic Field Reduction: Research Needs by Waller and Geissinger (1992) represents the task force's report. The conclusions of the task force were as follows:

- Known engineering techniques exist for lowering EMFs; 
- Given the same amount of energy delivered, the EMF reductions depend on the transmission-line design selected;

- Ways other than engineering techniques can be used to reduce the amount or duration of time that people are exposed to EMFs;

- Electric and magnetic fields from distribution systems and grounding of homes and buildings are important sources of EMF exposure;

- Electric and magnetic fields from distribution systems are much more difficult to manage than EMFs from transmission systems;

- Field strength is only one parameter of EMF exposure that should be considered when researching techniques of field management; and

- Ultimately, the choice of field reduction will depend on the benefit of reducing field exposure versus the costs of achieving that reduction.

Table B.4 presents construction costs from the Washington state report (Waller and Geissinger 1992) and the corresponding calculated EMF strengths.

\section{B.4 REFERENCES FOR APPENDIX B}

Commonwealth Associates, Inc., 1992, Cost Effectiveness Analysis: Mitigation of Electromagnetic Fields, Jackson, Mich., May.

Oppel, L.J., and J.R. Stewart, 1993, Attenuation of Electromagnetic Fields from Electrical Transmission Lines, PTI 25-93, Power Technologies, Inc., Schenectady, N.Y.

Waller, P., and L. Geissinger, 1992, Electric and Magnetic Field Reduction: Research Needs, Washington State Transmission Research Needs Task Force, Olympia, Wash., Jan. 
TABLE B.4 Calculated EMF Strengths versus Construction Cost Data from the Washington State Study

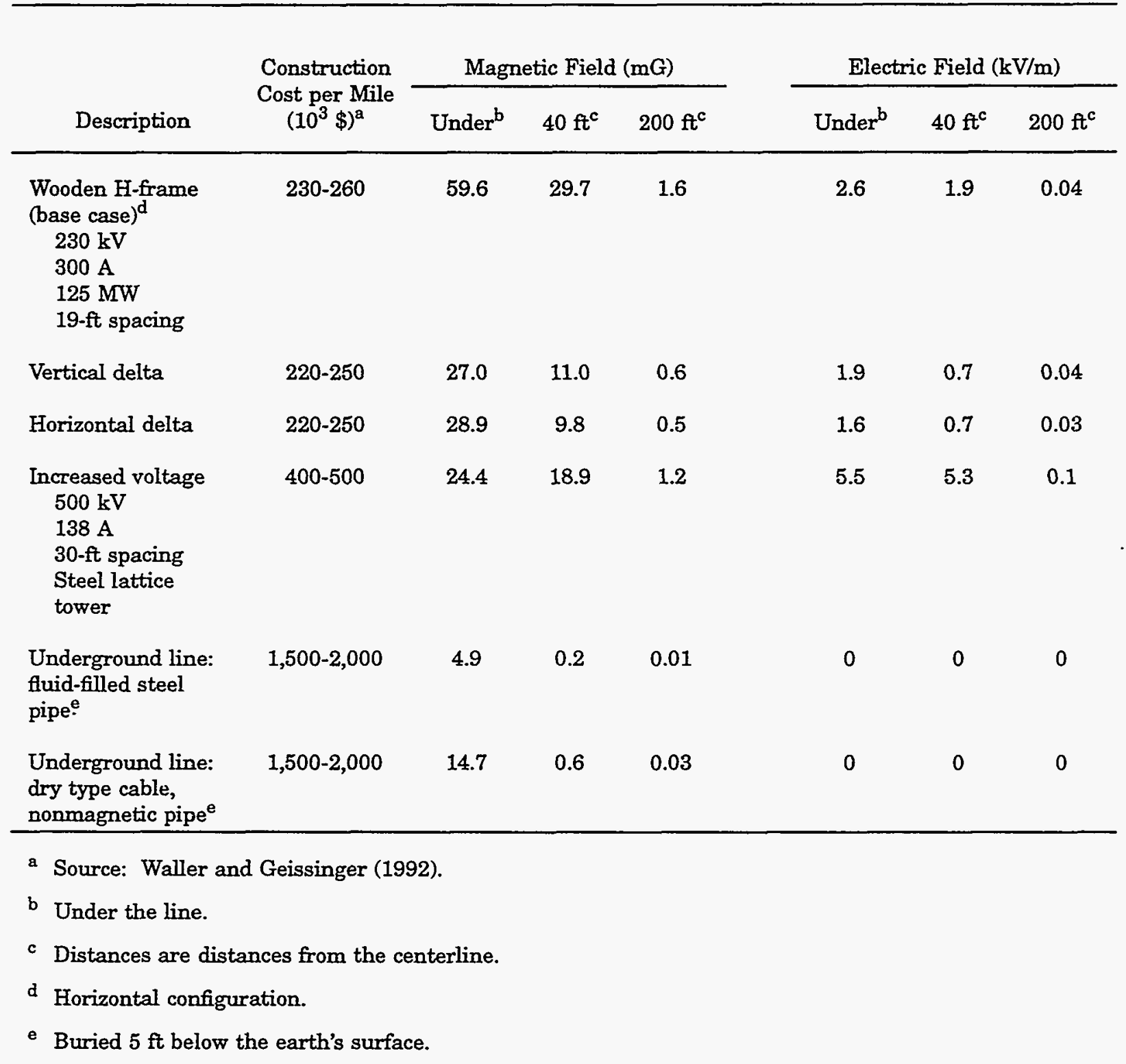

